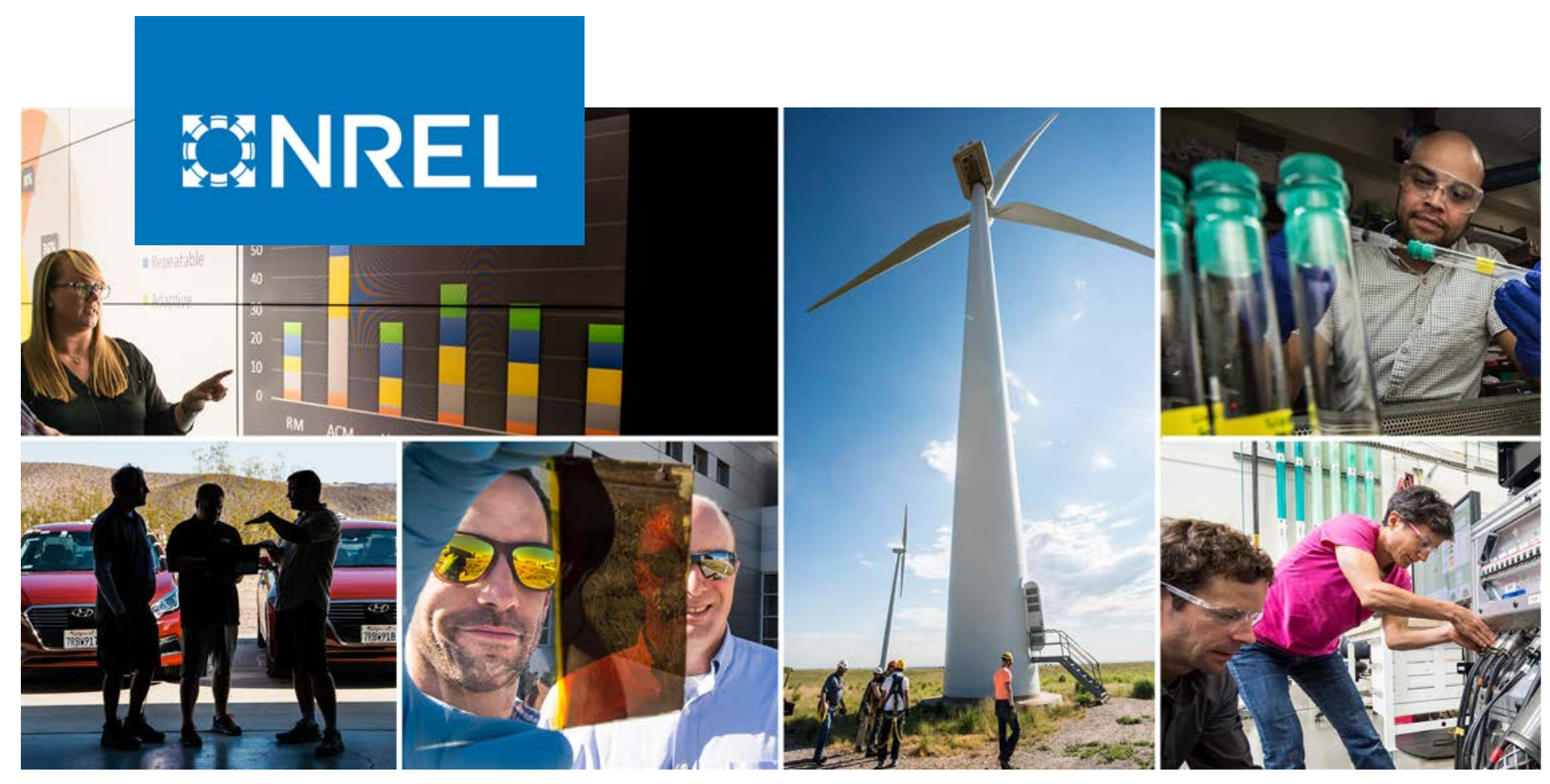

\title{
Global Ethanol-Blended-Fuel Vehicle Compatibility Study
}

Riley C. Abel, Kamyria Coney, Caley Johnson, Matthew J. Thornton, Bradley T. Zigler, and Robert L. McCormick

National Renewable Energy Laboratory

Produced under direction of the U.S. Grains Council by the National Renewable Energy Laboratory (NREL) under Agreement TSA-20-16712.

NREL is a national laboratory of the U.S. Department of Energy Office of Energy Efficiency \& Renewable Energy

Operated by the Alliance for Sustainable Energy, LLC

This report is available at no cost from the National Renewable Energy Laboratory (NREL) at www.nrel.gov/publications.
Strategic Partnership Project Report NREL/TP-5400-81252

November 2021 


\section{GNREL}

\section{Global Ethanol-Blended-Fuel Vehicle Compatibility Study}

Riley C. Abel, Kamyria Coney, Caley Johnson, Matthew J. Thornton, Bradley T. Zigler, and Robert L. McCormick

National Renewable Energy Laboratory

\section{Suggested Citation}

Abel, Riley C. Kamyria Coney, Caley Johnson, Matthew J. Thornton, Bradley T. Zigler, and Robert L. McCormick. 2021. Global Ethanol-Blended-Fuel Vehicle Compatibility Study. Golden, CO: National Renewable Energy Laboratory. NREL/TP-5400-81252. https://www.nrel.gov/docx/gen/fy22/81252.pdf.

NREL is a national laboratory of the U.S. Department of Energy Office of Energy Efficiency \& Renewable Energy Operated by the Alliance for Sustainable Energy, LLC

This report is available at no cost from the National Renewable Energy Laboratory (NREL) at www.nrel.gov/publications.

Contract No. DE-AC36-08GO28308
Strategic Partnership Project Report NREL/TP-5400-81252

November 2021

National Renewable Energy Laboratory 15013 Denver West Parkway Golden, CO 80401 303-275-3000 • www.nrel.gov 


\section{NOTICE}

This work was authored by the National Renewable Energy Laboratory, operated by Alliance for Sustainable Energy, LLC, for the U.S. Department of Energy (DOE) under Contract No. DE-AC36-08GO28308. Support for the work was also provided by the U.S. Grains Council under Agreement TSA-20-16712. The views expressed in the article do not necessarily represent the views of the DOE or the U.S. Government. The U.S. Government retains and the publisher, by accepting the article for publication, acknowledges that the U.S. Government retains a nonexclusive, paid-up, irrevocable, worldwide license to publish or reproduce the published form of this work, or allow others to do so, for U.S. Government purposes.

This report is available at no cost from the National Renewable Energy Laboratory (NREL) at www.nrel.gov/publications.

U.S. Department of Energy (DOE) reports produced after 1991 and a growing number of pre-1991 documents are available free via www.OSTI.gov.

Cover Photos by Dennis Schroeder: (clockwise, left to right) NREL 51934, NREL 45897, NREL 42160, NREL 45891, NREL 48097, NREL 46526.

NREL prints on paper that contains recycled content. 


\section{Acknowledgments}

The authors would like to thank the U. S. Grains Council for supporting this project and providing insightful direction and feedback. We would also like to thank Experian Information Solutions for help and flexibility in working with their vehicle fleet databases as well as MotorcyclesData for making their India and Indonesia data available. Finally, the authors would like to acknowledge valuable background discussions with several automotive original equipment manufacturers. 


\section{List of Acronyms and Abbreviations}

\begin{tabular}{|c|c|}
\hline AFDC & Alternative Fuels Data Center \\
\hline ANAFAVEA & $\begin{array}{l}\text { Associação Nacional dos Fabricantes de Veículos Automotores (Brazilian } \\
\text { Automotive Industry Association) }\end{array}$ \\
\hline CAP & Compliance Assurance Program \\
\hline $\mathrm{cc}$ & cubic centimeters \\
\hline DOE & U.S. Department of Energy \\
\hline ETBE & ethyl tert-butyl ether \\
\hline $\mathrm{EtOH}$ & chemical title for Ethanol Alcohol \\
\hline EIA & U.S. Energy Information Agency \\
\hline EPA & U.S. Environmental Protection Agency \\
\hline FFV & flex-fuel vehicle \\
\hline GDI & gasoline direct injection \\
\hline $\mathrm{HEV}$ & hybrid-electric vehicle \\
\hline LDV & light-duty vehicle \\
\hline $\mathrm{McD}$ & MotorcyclesData \\
\hline MIL & malfunction indicator lamp \\
\hline MTBE & methyl tert-butyl ether \\
\hline NLEV & National Low-Emissions Vehicle \\
\hline NREL & National Renewable Energy Laboratory \\
\hline OEM & original equipment manufacturer \\
\hline OPEC & Organization of Petroleum Exporting Countries \\
\hline ORNL & Oak Ridge National Laboratory \\
\hline PHEV & plug-in hybrid-electric vehicle \\
\hline RFA & Renewable Fuels Association \\
\hline RVP & Reid vapor pressure \\
\hline SAE & SAE International \\
\hline SEMARNAT & $\begin{array}{l}\text { Secretaría del Medio Ambiente y Recursos Naturales (Secretariat of } \\
\text { Environmental and Natural Resources for Mexico) }\end{array}$ \\
\hline SENER & Secretaría de Energía (Secretariat of Energy for Mexico) \\
\hline SI & spark ignition \\
\hline USGC & U.S. Grains Council \\
\hline VIO & Experian's Global Vehicles in Operation ${ }^{\mathrm{SM}}$ database \\
\hline vol. & volume \\
\hline wt. & weight \\
\hline
\end{tabular}




\section{Executive Summary}

The objective of this study is to understand the impact of ethanol-blended fuel at various blending levels $(10 \%, 15 \%$, and $20 \%$ vol.) on "in-operation" vehicles built to differing emissions and manufacturing standards around the world. The study focuses on vehicles used in Canada, China, India, Indonesia, Japan, South Korea, and Mexico. Historical experience in the United States and Brazil informs the analysis. The primary study question is:

\section{Are vehicles in targeted countries physically and operationally compatible} with ethanol blended fuel?

For a fuel to be compatible with a vehicle, the fuel must perform its function as part of the integrated fuel-vehicle system, meaning:

- The vehicle should start easily and drive normally

- The fuel should not cause catastrophic fuel system leaks

- The fuel should not cause corrosion or degradation of any engine or fuel system components (including emissions control components).

The history of E10 use in the United States, beginning in 1978, was evaluated and shows no reliability or operability issues for vehicles dating back to pre-emissions-control times - and likely included many vehicles manufactured in the 1960s. This strongly supports the contention that fuel chemistry and property differences between E0 and E10 are so small that any vehicle made to international standards in the last 50 years will have a very high probability of being fully compatible with E10. This conclusion is supported by the experience in Brazil in the 1970s, where E10 was also introduced, and ethanol blending for conventional vehicles rapidly ramped up to even higher blend levels. A limited number of fuel system and component manufacturers supply the global market, including Bosch, Continental, Denso, Delphi, and Visteon. To reduce complexity, ethanol-compatible materials began to be integrated in fuel system designs globally. Fuel systems evolved over the following decades to incorporate ethanol-compatible materials with core subsystem families, such as in-tank fuel pumps used across several global vehicle original equipment manufacturers (OEMs).

A similarly compelling case can be made that all vehicles at the Tier 1 (or equivalent) emissionscontrol technology level or higher are fully compatible with E15 blends, based on the data evaluated by the U.S. Environmental Protection Agency (EPA) and Ricardo in 2010. For vehicles at this technology level, the minor differences in fuel chemistry and properties between E10 and E15 are not significant. For E20, studies are not as extensive but are still highly significant. A long-term durability study conducted on mileage accumulation dynamometers presents convincing evidence that Tier 2 technology level vehicles have materials of construction and engine control authority for compatibility with E20, although this conclusion is not as strong as those drawn for E10 and E15, which are also partly based on real-world experience.

For vehicles, our approach to assessing ethanol blend compatibility in the study countries is to first evaluate the emissions standards that have been in place historically and to correlate these standards with similar U.S. standards - as emissions standards are indicative of vehicle technology level. We then utilize the Experian Vehicles in Operation database to profile the fleets of light-duty vehicles (LDVs) in the studied countries by model year and emissions 
standard technology level. This leads to an initial conclusion regarding ethanol compatibility (with all LDVs considered as highly likely of being compatible with E10). Corroborating information is then sought from other sources, such as owners manuals and surveys of fuel oxygenate content, that may already be used in the study countries.

The stock of motorcycles and scooters is profiled for India and Indonesia using the MotorcyclesData database and other sources. Information from this database is compared to emissions standards in place historically, ethanol usage in other countries with similar motorcycle technology, and ethanol use in the study country. Conclusions drawn are augmented by a limited owners manual survey.

While our analysis indicates that all LDVs in the study countries are highly likely compatible with E10, a similar analysis for motorcycles in India and Indonesia indicates full compatibility with E10 — and that many motorcycles are also compatible with E15.

Brief conclusions follow on vehicle fleet ethanol compatibility for each country:

- China - fourth-largest ethanol-producing nation. The CN 2 standard, equivalent to Euro 2, was introduced in 2004. As Euro 2 is roughly equivalent to U.S. Tier 1, at least $98 \%$ of the LDVs in China should be compatible with blends up to E15. This is supported by widespread use of E10 in China and the existence of a national standard for E10 fuels.

- Japan - adopted an emissions standard similar to U.S. Tier 0 in the early 1980s. Tier 1 emissions were required beginning in 2000, and Tier 2 beginning in 2005. New LDVs registered since 2000 should be compatible with E15-although we do not know the breakdown of model years for 2005 and older LDVs. However, given that the gasoline standard only allows E3 blends, additional investigation may be required to understand ethanol compatibility in the Japanese market.

- India-India's National Biofuel Policy has a goal of E10 by 2022 and will phase in E20 blending from 2023 to 2025. E20 blends with meet the IS 17021:2018 standard. Since 2005, new LDVs sold in India were required to meet the Bharat Stage (BS) II standard, paralleling the Euro 2 emissions standard and roughly equivalent to U.S. Tier 1, such that these and newer LDVs should be compatible with E15. Pre-2005 LDVs make up 11\% of the gasoline LDV fleet and should be compatible with E10. Indian motorcycles met the BS I (Euro 1) emissions standard beginning in 2000 and the BS II (Euro 2) emissions standard in 2005. In other parts of the world, motorcycles meeting these or equivalent standards are considered compatible with E10.

- Mexico - ethanol is allowed in Mexico at up to 5.8\% vol. (except for the large metropolitan areas of Mexico City, Monterrey, and Guadalajara where ethanol blending is not allowed). However, in the northern border states, regulations have allowed importation of U.S. finished gasoline, which is largely E10. Vehicles manufactured in 2004 and later and having Tier 1 emissions technology level (57\% of the vehicle fleet), should be compatible with blends up to E15, according to our analysis.

- South Korea - it appears that no fuel ethanol is currently used in South Korea. Given the high level of emissions-control technology for the entire fleet of LDVs in South Korea, these LDVs should be compatible with blends up to E15.

- Canada - this market is very similar to the United States in almost every regard. It has heavy overlap in manufacturers, manufacturing facilities, engines, and models. Therefore, given 
this and the overall high level of emissions-control technology of Canadian LDVs, it is likely that most new LDVs sold since 1998 are E15 compatible.

- Indonesia - even though current policy mandates blending of E10 in 2020, ethanol is not currently being blended in Indonesia. Emissions standards equivalent to Tier 1 were introduced in 2005, and equivalent to Tier 2 in 2018. A combined $68 \%$ of LDVs meet these requirements. Vehicles manufactured since 2005 that have Tier 1 emissions technology level or higher should be compatible with blends up to E15. Indonesia implemented Euro 2 emissions requirements for motorcycles in 2005, and Euro 3 in 2015. In other parts of the world, motorcycles having this level of technology are compatible with E10.

We did not identify any specific engine or vehicle designs or engineering practices that could cause issues when operating on ethanol. 


\section{Table of Contents}

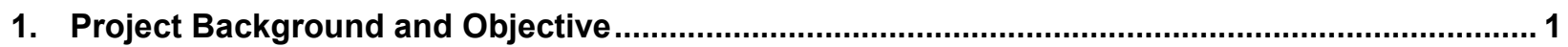

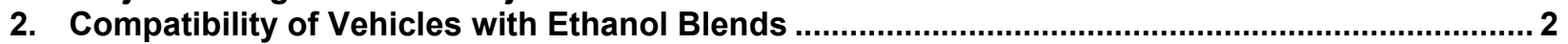

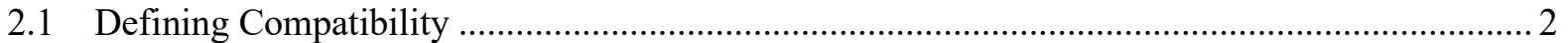

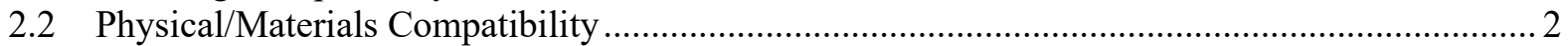

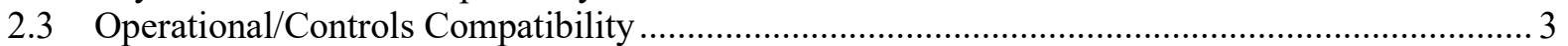

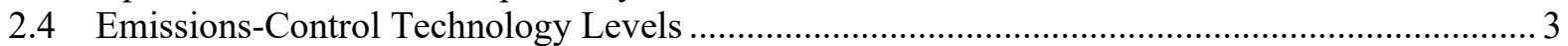

2.5 Historical Usage of Ethanol Blends in the United States and Brazil.......................................... 4

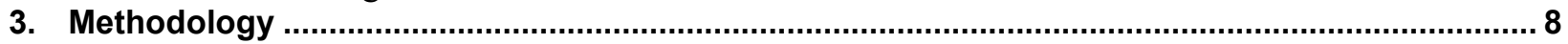

4. Light-Duty Vehicle Emissions Standards and Fleet Profiles in Study Countries ....................... 10

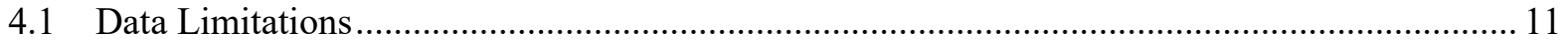

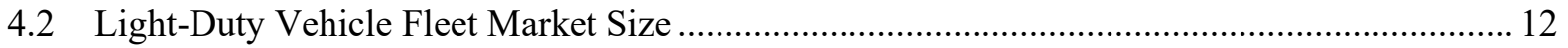

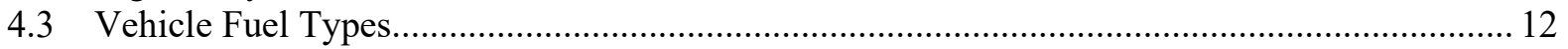

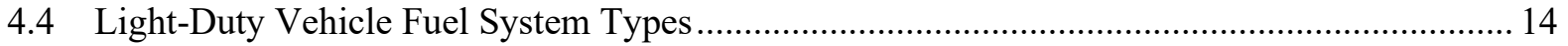

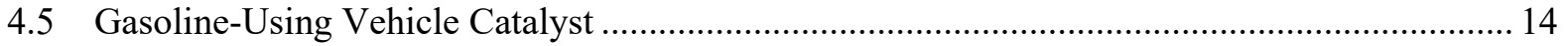

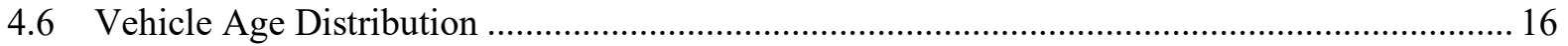

4.7 Vehicle Model Year and Emissions Standard for Study Countries ........................................ 17

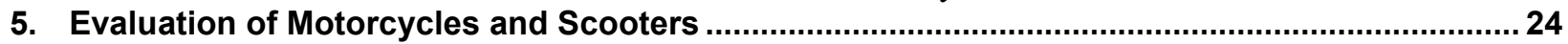

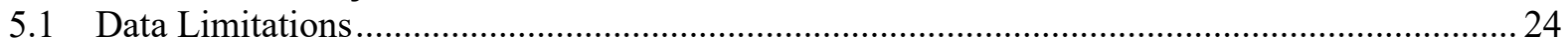

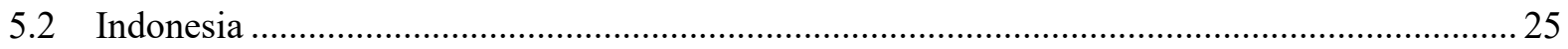

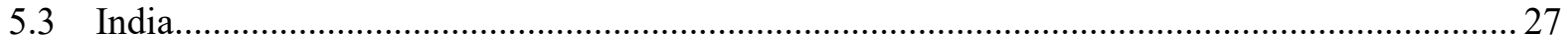

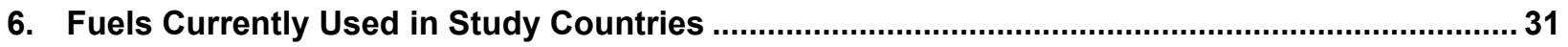

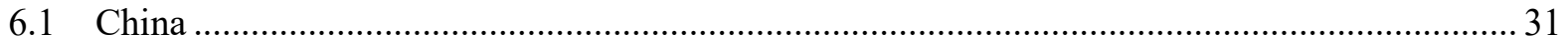

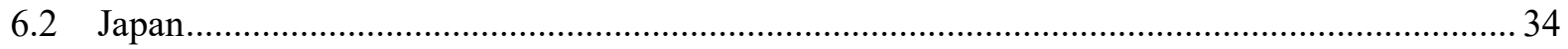

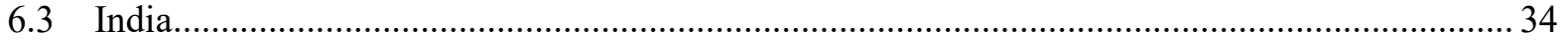

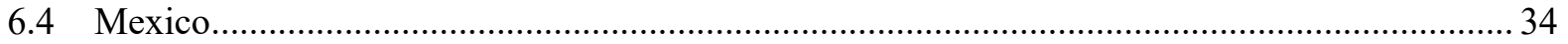

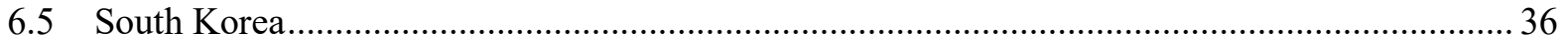

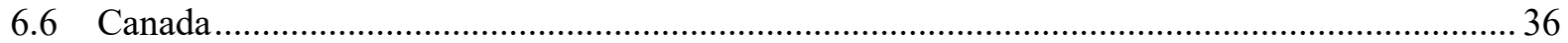

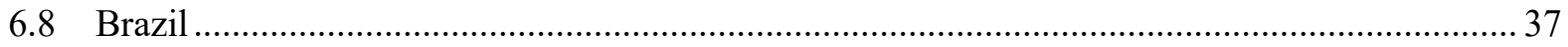

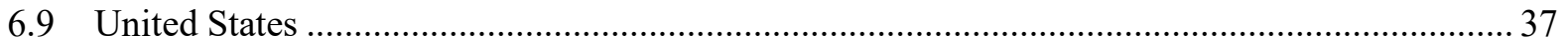

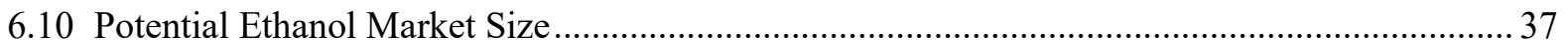

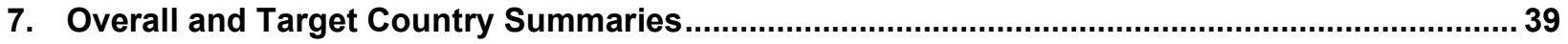

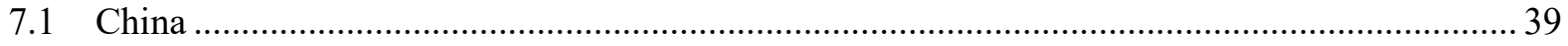

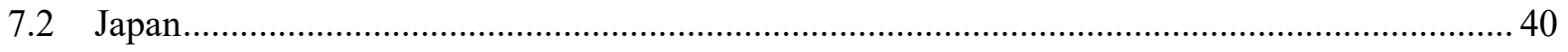

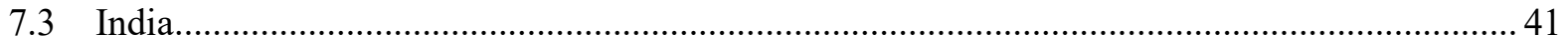

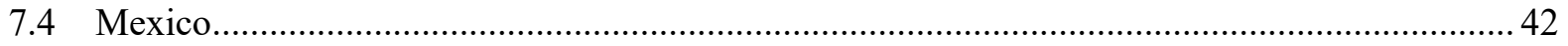

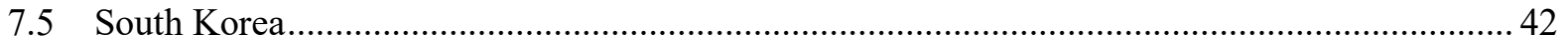

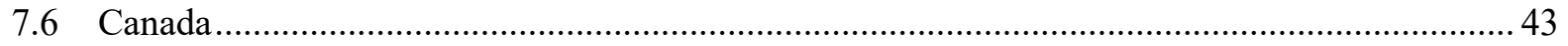

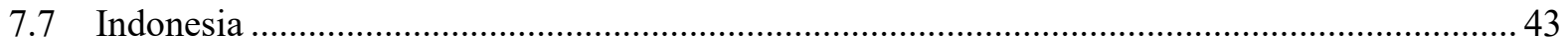

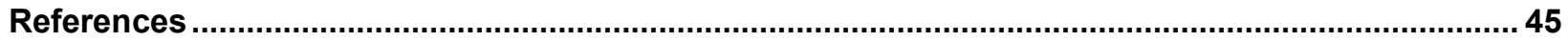

Appendix A. Materials Compatibility with Ethanol Blends ....................................................... 55

Appendix B. GasPlus Waiver Request for EPA Approval of E10 Blends......................................59

Appendix C. Additional Analyses of Vehicle Fleet Data .................................................................63 


\section{List of Figures}

Figure 1. New automobile registration data for Brazil (Associação Nacional dos Fabricantes de Veículos

Automotores - ANFAVEA, 2021)

Figure 2. New automobile registrations by fuel type for Brazil (ANFAVEA, 2021) ................................ 7

Figure 3. Emissions standards over time for the study countries, plus Brazil and the United States ......... 10

Figure 4. Approximate equivalence to U.S. emissions standards for the study countries ........................ 11

Figure 5. LDVs in operation in seven study countries plus Brazil and the United States ........................ 12

Figure 6. LDVs by fuel type in operation in seven study countries, plus Brazil and the United States ..... 13

Figure 7. Gasoline-using LDVs in operation in seven study countries, plus Brazil and the United States 14

Figure 8. Gasoline-using LDVs by fuel system ........................................................................... 15

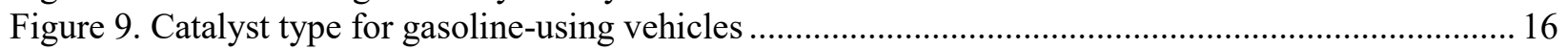

Figure 10. Gasoline-using vehicle age distribution and emissions standards for China........................... 18

Figure 11. Gasoline-using vehicle age distribution and emissions standards for Japan .......................... 19

Figure 12. Gasoline-using vehicle age distribution and emissions standards for India ............................ 20

Figure 13. Gasoline-using vehicle age distribution and emissions standards for Mexico ......................... 21

Figure 14. Vehicle age distribution and emissions standards for South Korea........................................ 22

Figure 15. Vehicle age distribution and emissions standards for Canada.............................................. 22

Figure 16. Vehicle age distribution and emissions standards for Indonesia ........................................ 23

Figure 17. Motorcycle and automobile registrations in Indonesia, 2012-2019.................................. 25

Figure 18. Units registered for the five major motorcycle manufacturers in Indonesia, 2012-2020 ........ 26

Figure 19. Engine displacements of motorcycles registered in Indonesia from 2012-2020 ................... 26

Figure 20. Motorcycle and automobile registrations in India from 2012-2019 ..................................28

Figure 21. Wholesale numbers for the 10 major motorcycle manufacturers in India from 2012-2020 .... 28

Figure 22. Engine displacements of new motorcycle wholesale units in India from 2012-2020............. 29

Figure C-1. Percent of vehicles in studied and comparison countries by country of origin ...................... 63

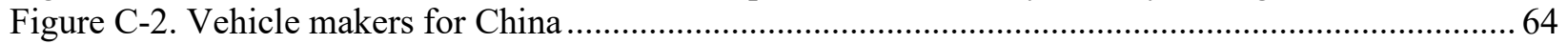

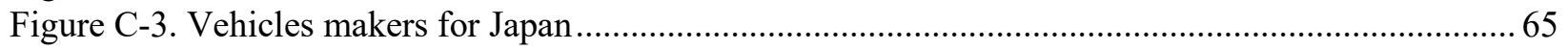

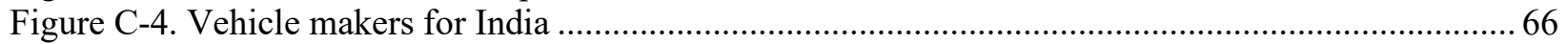

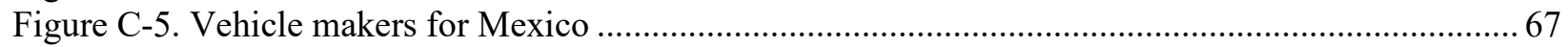

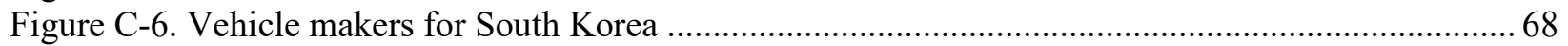

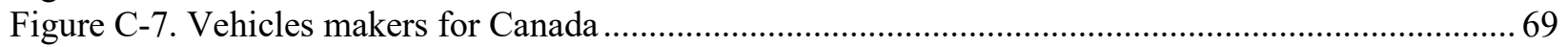

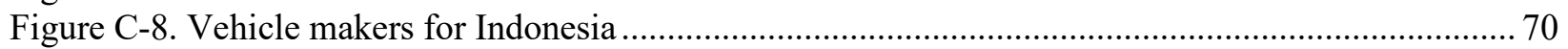

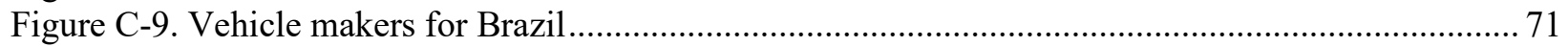




\section{List of Tables}

Table 1. Vehicle Age by Country .................................................................................................... 17

Table 2. Oxygenates Observed in Survey Gasolines in Study Countries .............................................. 32

Table 3. Fuel Composition and Property Results for Survey Gasolines in Study Countries ...................... 33

Table 4. Gasoline Consumption of the Study Countries and Potential Ethanol Consumption at Various

Blend Levels (millions of gallons/year) - 2018 or 2019 Data ............................................. 38 


\section{Project Background and Objective}

Ethanol is a renewable, high-octane-number blendstock that has been used at different times and different blend levels since the beginning of the automobile era. Ethanol is commonly blended into gasoline at levels ranging from 5\% vol. to 20\% vol. (E5 to E20)-although much higher blend levels (e.g., E85 and E100) can be used in specially designed vehicles. At lower blend levels, differences are small in fuel properties and performance in comparison to petroleum gasoline; but, at some blend level, it is possible that issues with materials compatibility or control of air-to-fuel ratio could begin to occur.

Ethanol is blended at E10 in virtually every gallon of gasoline sold in the United States today. U.S. ethanol producers provide nominally 16 billion gallons of ethanol per year, making the United States the world's largest producer-and, over the past year, 1.3 billion gallons were exported (RFA 2021). The U.S. Grains Council (USGC) is examining the potential to develop new export markets for ethanol.

The goal of this study is to understand the impact of ethanol-blended fuel at various blending levels $(10 \%, 15 \%$, and $20 \%$ vol.) on "in-use" vehicles built to differing emissions and manufacturing standards around the world. To our knowledge, no one has ever examined the global automobile fleet for the purpose of determining if these vehicles could use E10 — or even higher-ethanol blends.

Because vehicle markets can differ dramatically from country to country, this study attempts to address the following questions:

- Are vehicles in targeted countries physically and operationally compatible with ethanolblended fuel?

- What ethanol blend levels are compatible with most of the existing fleet?

- With such a large and diverse fleet of automobiles in use, are there vehicles that were not designed to use ethanol? Are there any vehicle engineering practices that make a certain type of vehicle prone to issues when operating on ethanol?

This study will also provide an overall assessment of the current vehicle fleet from the perspective of age, vehicle type, and brand, as well as emissions standards and other aspects of the automobile and fuel markets in the target countries. The study focuses on automobiles used in China, Japan, India, Mexico, South Korea, Canada, and Indonesia (in order of vehicle fleet size), along with Brazil and the United States, for comparison. And, because motorcycles and scooters dominate the markets for India and Indonesia, the motorcycle fleets for these countries are assessed. 


\section{Compatibility of Vehicles with Ethanol Blends}

In this chapter, we define vehicle compatibility with ethanol blends. Then we review the two ways in which ethanol blends might be incompatible with vehicles - (1) materials incompatibility, and (2) engine control authority to compensate for the oxygenated fuel. We also discuss emissions-control technology levels. Finally, we review the history of fuel ethanol use in the United States and Brazil, considering vehicle technology level (as measured by vehicle emissions-control requirements). This allows conclusions to be drawn regarding the compatibility of vehicles with E10, E15, and, to some extent, E20.

\subsection{Defining Compatibility}

A dictionary definition of compatibility is:

The ability to function or be integrated with other parts of any system.

For a fuel to be compatible with a vehicle, the fuel must perform its function as part of the integrated fuel-vehicle system:

- The vehicle should start easily and drive normally

- The fuel should not cause catastrophic fuel system leaks

- The fuel should not cause corrosion or degradation of any engine or fuel system components (including emissions-control components).

There are two ways in which new gasoline fuels could potentially impact vehicle operation (McCormick et al. 2013):

- Materials compatibility. In some cases, new fuels are found to be incompatible with elastomers (e.g., hoses, o-rings, seals), plastics, or metal coatings.

- Authority to control engine air-fuel ratio. Significant deviations from stoichiometric operation in spark-ignition (SI) engines can impact emissions and performance, including driveabilty and, in some cases, component durability.

\subsection{Physical/Materials Compatibility}

A wide variety of plastics, elastomers, and metals can be found in automotive and motorcycle fuel system components. Material compatibility issues can cause degradation of these components, leading to premature wear and/or failure, including fuel leaks and increased evaporative emissions. Elastomer property changes, when exposed to fuel, include swell, tensile strength, and elongation (Bechtold et al. 2007). Plastic properties that can change upon exposure to fuel include swell, hardness, tensile strength, impact strength, dimensional stability, plasticization, and permeation (Bawase et al. 2013). Assessments for blends up to E20 have found only minor changes in elastomer and plastic performance (Kass et al. 2011; Kass et al. 2014; Bawase et al. 2017).

Metals or metal coatings can be affected by ethanol, although this is uncommon and studies using standard auto industry protocols have not found issues with E10 or E20 compatibility (Durbin et al. 2016; Vyas et al. 2013). Some aluminum parts experienced pitting corrosion when 
exposed to E10 blends, which was addressed by changing the passivating coating (Park et al. 2011). Table A-1, provided in Appendix A, summarizes materials compatibility details.

Low-level ethanol blends in gasoline first appeared in the United States in limited regional markets in the late 1970s with very few reports of materials issues. Nevertheless, this prompted U.S.-market vehicle original equipment manufacturers (OEMs) to assess impacts of ethanol blends on materials. As U.S.-market light-duty vehicles (LDVs) adapted to $10 \%$ vol. ethanol blends (E10), lessons learned spread to key global vehicle manufacturers of fuel systems and components. A limited number of fuel system and component manufacturers supply the global market, including Bosch, Continental, Denso, Delphi, and Visteon. To reduce complexity, ethanol-compatible materials were integrated into fuel system designs globally. Fuel systems evolved over the following decades to incorporate ethanol-compatible materials, with core subsystem families such as in-tank fuel pumps used across several global vehicle OEMs. In general, common use of materials poorly compatible with low-level ethanol blends (E5, E10) was likely phased out. However, specific components for limited applications in some regional markets not using ethanol blends may not have transitioned because of production economics. Increasing ethanol content to higher-level flex-fuel blends (E85, E100) requires additional material considerations, including metals compatibility, but the engineering required for these fuels is well established.

\subsection{Operational/Controls Compatibility}

Another important aspect is the ability to control the air-fuel ratio for fuels that contain oxygenates, such as ethanol or methyl tert-butyl ether (MTBE). Since the early 1980s in the United States, LDVs and trucks with SI engines have incorporated an exhaust oxygen sensor that signals the engine control system to control air-fuel ratio such that there is just enough air to burn the fuel. Adding oxygen to the fuel by blending ethanol reduces the amount of air needed. Very early LDVs with exhaust-oxygen sensors may not have had the control authority to compensate for fuel oxygen to the degree necessary for blends such as E20 or higher. The result was that the engine operated lean (i.e., with too much air relative to the fuel) — a situation known as enleanment. Enleanment can cause higher exhaust temperatures that might reduce exhaust valve and emissions-control catalyst life. In addition, enleanment can contribute to drivability issues, including difficulty to start, hesitation, and stumble, and lead to increased $\mathrm{NO}_{x}$ emissions.

Historical experience, described below, suggests that fuel oxygen compensation was not necessary for operating on E10 blends with pre-emissions-control LDVs and was adequate for early LDVs with oxygen sensors. Typical modern LDVs can compensate for oxygenates, including ethanol, up to a certain volume percentage. For 2001 and newer LDVs sold in the United States, emissions studies show that engine control units can adequately compensate for the higher oxygen and lower energy content of E15 blends and, potentially, for E20 blends (McCormick et al. 2013).

\subsection{Emissions-Control Technology Levels}

The following list describes U.S. emissions technology levels and how they relate to ethanol or oxygenate compatibility: 
- Pre- $\mathrm{NO}_{x}$ control - vehicles with oxidation catalysts to control $\mathrm{CO}$ and unburned hydrocarbons (sometimes called two-way catalysts) were introduced in the United States in the late 1970 s.

- Tier 0 - fully implemented in 1981, requires closed-loop control of air-fuel ratio (using an exhaust oxygen sensor) and a three-way catalyst that reduces $\mathrm{CO}$, unburned hydrocarbons, and $\mathrm{NO}_{x}$. Fuel introduction was via a carburetor. Air-fuel ratio control was relatively crude compared with later technologies.

- Tier 1 -implemented in 1994, Tier 1 lowered allowable levels of hydrocarbon and $\mathrm{NO}_{x}$ emissions, which required more sophisticated air-fuel ratio control and control of the engine during a cold start. This emissions level coincided with the introduction of port fuel injection technology that replaced carburetors. Evaporative emissions controls were also introduced, requiring more durable fuel system plastics and elastomers that may be more compatible with oxygenates. Oxygenated fuels containing ethanol and MTBE had become widely used in the United States, and these LDVs are likely fully compatible with E10 by design. The Tier 1 standards became stricter over time with the introduction of the National Low Emissions Vehicle (NLEV) program in 1999 and the requirement of additional testing using the Supplemental Federal Test Procedure in 2000. The NLEV program was fully phased-in in 2001 - as was the U. S. Environmental Protection Agency's (EPA's) Compliance Assurance Program (CAP2000), which requires in-use testing of LDVs over their full useful life to ensure emissions compliance. The EPA approved the use of E15 blends in 2001 and newer LDVs meeting these requirements.

- Tier 2-this standard was phased-in between 2004 and 2009 with significantly reduced emissions levels compared with Tier 1 and an increased emissions compliance period to 120,000 miles. These standards coincided with a reduction in gasoline sulfur content because sulfur negatively impacted three-way catalyst performance. Gasoline direct injection technology began to replace port fuel injection in 2008 to improve transient response of airfuel ratio control and to improve fuel economy.

- Tier 3-this standard is being phased-in between 2017 and 2025 with lower emissions levels for all pollutants and, for the first time, uses an E10 blend for emissions certification testing.

\subsection{Historical Usage of Ethanol Blends in the United States and Brazil}

\subsubsection{Modern Ethanol Usage in the United States}

Modern fuel ethanol production in the United States began in 1978 with passage of the Energy Tax Act that provided a \$0.40/gallon tax exemption for E10 blends (Morris, 1992; Duffield and Collins, 2006). The same year, the EPA granted a waiver for gasohol—a blend of $90 \%$ unleaded gasoline and $10 \%$ ethanol. The waiver petition cites extensive test data for methanol, ethanol, and t-butyl alcohol, in support of the request and is attached as Appendix B. Several published studies showed no operational or performance issues for LDVs using E10 (e.g., Joseph and Grogan, 1980; Gibbs and Gilbert, 1981). Dorn and coworkers of Texaco reviewed the early literature in 1986 - including the studies cited in the GasPlus waiver request - and noted that "up to $3.5 \% \mathrm{wt}$. oxygen in gasoline, as represented by $10 \%$ ethanol ... is being successfully marketed and is generally accepted as providing satisfactory performance." (Dorn et al. 1986). They also concluded that E10 did not cause any "significant metal corrosion or elastomer compatibility problems." While Tier 0 feedback control systems could control air-fuel ratio for a limited range, very early systems only maintained control for certain steady-state operating modes and, 
therefore, may only have limited control authority to compensate for ethanol blends above E10 (Seiter et al. 1978).

Ethanol blending in the United States expanded significantly in subsequent decades as the result of several incentives and policies as well as the phase out of the competing oxygenate MTBE. By 2010, ethanol production exceeded 13 billion gallons per year (RFA 2021) such that a very high percentage of gasoline in the United States was E10 (more than 90\%).

In 2010 and 2011, based on an extensive multiyear research program (McCormick, 2013), the EPA granted waivers for the use of E15 blends in model year 2001 and newer LDVs in the United States (EPA 2010; EPA 2011). From a vehicle technology level perspective, this waiver applied to a subset of Tier 1 LDVs that also met the CAP2000 requirements as well as newer technology LDVs. At the same time, the international automotive engineering firm, Ricardo Inc., conducted a study evaluating the compatibility of U.S. 1994-2000 model year LDVs with E15 (Tier 1 LDVs produced prior to full implementation of the CAP2000 program) (Ricardo Inc., 2010). The study included an evaluation of the types of fuel systems used, the materials of construction, emissions and diagnostic regulations, emissions data, emissions-control systems and calibrations, as well as physical examination of fuel system parts from 1994-2000 model year LDVs that were still in use in 2010. The analysis concluded that "the adoption and use of E15 would not adversely affect fuel system components in properly engineered vehicles, nor would it cause them to perform in a suboptimal manner when compared to the use of E10."

Several important studies were conducted on U.S. LDVs operating on E20 blends. Many of these studies are summarized in Yanowitz, et al. 2013. These include several materials compatibility studies for metals, elastomers, and plastics that found no significant differences between their performance with E10 and E20. The summary also includes several studies of fuel pump and fuel level sender durability that, overall, show no differences between E20 and lower-level ethanol blends. A drivability study conducted on 80 mostly Tier 1 LDVs over 13 months found no measurable differences in performance of E0 and E20 (Kittleson, et al. 2008). A study of malfunction indicator lamp (MIL) illumination (which can occur when the engine control system cannot adequately control air-fuel ratio) found the potential for MIL illumination was less than $1 \%$ for all LDVs studied for E10, E15, and E20 (Sluder, et al. 2012). A study of Tier 2 LDVs aged on mileage accumulation dynamometers for up to 120,000 miles found no evidence of emissions-control catalyst deterioration for E20 relative to E0 (West, et al. 2012). Post durability engine inspections showed increased intake valve deposits for the E15 and E20 ethanol blends, likely because splash blending into conventional gasoline designed for E10 blending had diluted the detergent additive. No abnormal degradation was observed for any engine or fuel system components (Shoffner, et al. 2011).

The history of E10 use in the United States shows no reliability or operability issues dating back to pre-emissions control and likely including many LDVs manufactured in the 1960s. This strongly supports the contention that fuel chemistry and property differences between E0 and E10 are so small that any vehicle made to international standards in the last 50 years will have a very high probability of being fully compatible with E10. The data evaluated by the EPA and Ricardo Inc. for E15 presents a similarly strong case that all LDVs at the Tier 1 technology level or higher are fully compatible with E15 blends - for these LDVs, the minor differences in fuel chemistry and properties between E10 and E15 are not significant. For E20, studies are not as 
extensive but are still highly significant. The long-term durability study conducted on mileage accumulation dynamometers presents convincing evidence that Tier 2 technology level LDVs have construction materials and engine control authority for compatibility with E20, although this conclusion is not as strong as for those drawn for E10 and E15, in part because of relatively little real world experience with E20.

\subsubsection{Ethanol Fuel Use in Brazil}

Modern usage of fuel ethanol in Brazil began with the Pro-Alcool program in 1975 in response to the oil supply crisis and price precipitated by the Organization of Petroleum Exporting Countries (OPEC) oil embargo. The government supported the rapid development of vehicles that ran on hydrous E95 (often referred to as E100 or, simply, ethanol). This support was accelerated by the fact that, prior to 1990, virtually all new LDVs sold in Brazil were manufactured in Brazil (Figure 1) by the global automakers, such as Volkswagen, Fiat, General Motors, Ford, and others. Throughout the last 50 years, Brazil has maintained relatively high import tariffs and taxes that favor vehicle production in-country (U.S. Trade Representative, 2021). Vehicles designed to run on E100 dominated the Brazilian market through most of the 1980s (Figure 2).

In 1977, the Brazilian government mandated anhydrous ethanol blending into gasoline for gasoline-powered LDVs at 10\% vol., increasing to $15 \%$ vol. in $1982,22 \%$ vol. by 1992 , and as high as 27\% vol. in 2015. In 1975-1979 in Brazil conventional LDVs not designed to run on any blend level of ethanol were operating on E10, which was increased to E20 in 1979—without dramatic fuel compatibility problems (Meyer et al. 2012). Later in the 1980s, registrations of new conventional gasoline LDVs dropped to near zero as the market was dominated by E100 LDVs (Figure 2).

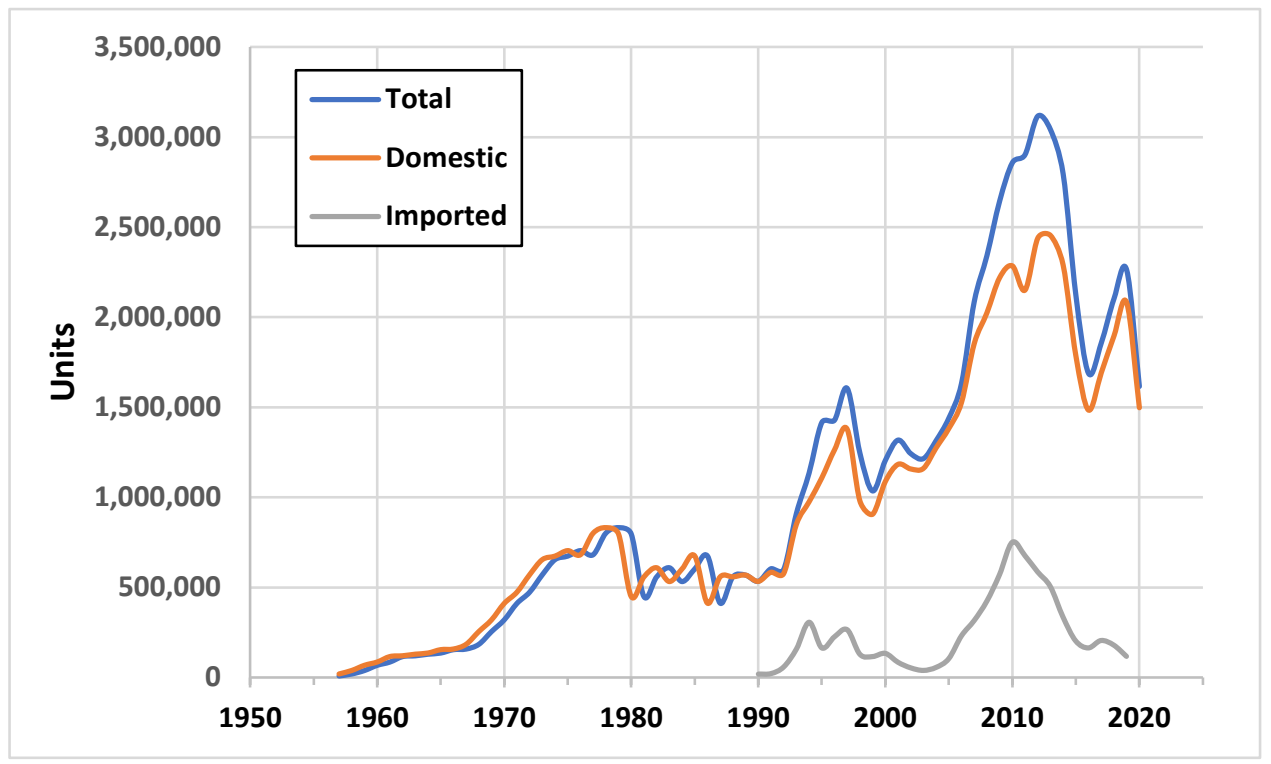

Figure 1. New automobile registration data for Brazil (Associação Nacional dos Fabricantes de Veículos Automotores - ANFAVEA, 2021) 


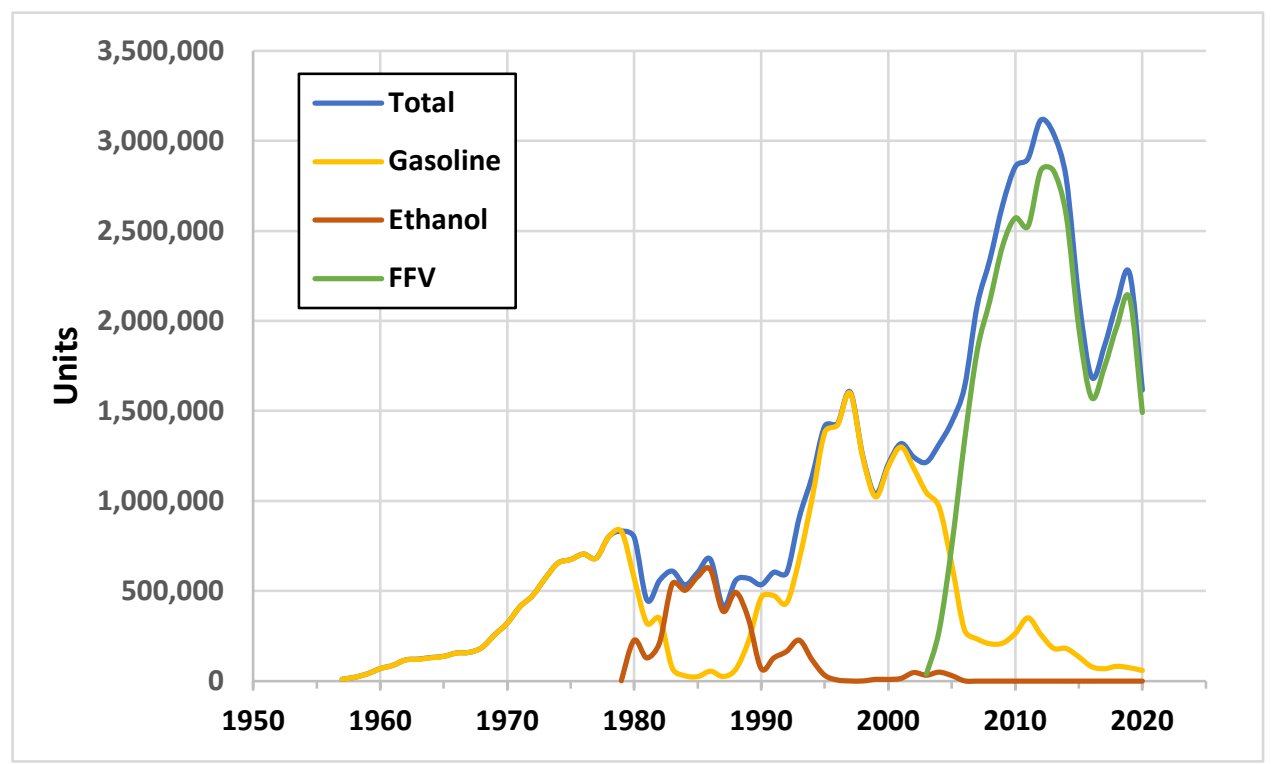

Figure 2. New automobile registrations by fuel type for Brazil (ANFAVEA, 2021)

Ethanol production and sales of E100 vehicles dropped dramatically in the late 1980s because of a large drop in global oil prices, but perhaps more importantly because of a shortage of ethanol, leaving E100 vehicle owners with no fuel for their vehicles (Dickerson, 2005; Veja, 1999). This led to a large drop in sales of E100 vehicles, which were replaced by conventional gasoline vehicles that operated on blends up to E27. Because these vehicles were mostly produced in Brazil, it seems likely that by the late 1980s these vehicles had engines and fuel system components specifically designed to tolerate this relatively high ethanol level. In 2003, flex-fuel vehicles (FFVs) were introduced into the Brazilian market - vehicles capable of operating on any level of ethanol from E20 to E100. Increasingly, these vehicles have engines optimized for the high-octane number of E20 or higher blends, as E0 is not allowed (The Royal Society, 2008). In the $21^{\text {st }}$ century, FFVs have grown to dominate the Brazilian market. 


\section{Methodology}

The review of historical experience with ethanol blends in the United States and Brazil indicates the following guidelines for determining current vehicle compatibility with ethanol blends:

- There is little or no evidence of compatibility issues for use of E10 in U.S. LDVs dating back to the 1960s (in use in the late 1970s) or in Brazilian conventional LDVs from the same time period, including pre-emissions-control LDVs

- Thus, it is highly likely that virtually all LDVs globally are compatible with E10

- Vehicles made to international standards and meeting Tier 1 emissions requirements (since 1994 in the United States) have a very high probability of being compatible with E15 as well

- While non-FFVs in Brazil routinely operate on E20+ blends, these LDVs likely have components optimized for these blends

- Published research on E20 strongly indicates that Tier 2 and newer LDVs are compatible with this fuel; however, this conclusion is not as strongly supported as those for E10 and E15.

In Chapter 4, on LDVs, our approach to assessing ethanol compatibility in the study countries is to first evaluate the emissions standards that have been in place historically and to correlate these standards with similar U.S. standards - because emissions standards are indicative of vehicle technology level. We then utilize Experian's Global Vehicles in Operation ${ }^{\mathrm{SM}}$ (VIO) database to profile the fleets of LDVs in the studied countries by model year and emissions-standard technology level. This leads to an initial conclusion regarding ethanol compatibility.

Corroborating information is then sought from other sources, such as owners manuals and surveys of fuel oxygenate content that may already be used in the study countries.

Additionally, NREL reached out to most of the global light duty automobile OEMs. The consistent "official" feedback from all may be paraphrased as: Ethanol blend compatibility is whatever is written in owners manuals for specific years and vehicle models for specific markets, which in turn addressed whatever gasoline specifications were in place for those markets at the time those LDVs were manufactured. However, ethanol blends such as E10 were used in the United States, Brazil, and likely other countries long before ethanol was mentioned in owners manuals. This study attempts to address some of the uncertainty beyond that to consider the potential in introducing ethanol blends to current fleets in the subject countries where ethanol is not mentioned in owners manuals.

Vehicle ethanol blend recommendations according to owners manuals may differ depending on the region or destination of a specific make and model. This is evident with Toyota, as the Toyota Camry for model years 2017-2021, marketed in Japan, clearly states within the owner's manual to not use gasoline containing more than $10 \%$ ethanol; the manual for the Toyota Camry produced for the U.S. market allows up to $15 \%$ ethanol since model year 2015.

An owner's manual survey was conducted based on the most popular manufacturers and models, where available. Not every manufacturer provides owners manuals via web-based search, and not every manufacturer clearly states ethanol blend recommendations within the manual. For the countries that do not currently use ethanol or use it in very low-volume percentages, the owners manuals may state guidance for other oxygenates [e.g., MTBE, ethyl tert-butyl (ETBE), or 
oxygen content allowance]. The owners manual ethanol recommendations review was a small percentage of each of the study countries fleet population and, in most cases, only covered model years 2013 onward.

In Chapter 5, the stock of motorcycles and scooters is profiled for India and Indonesia using the MotorcyclesData database and other sources. This is compared to emissions standards in place historically, ethanol use in other countries with similar motorcycle technology, and ethanol use in the study country. Conclusions drawn are augmented by a limited owners manual survey.

The fuel market in the target countries is then assessed in terms of fuel quality and current oxygenate use, including ethanol, in Chapter 6. In general, the use of oxygenates in the study countries confirms the ability of their vehicle and motorcycle fleets to compensate for air-fuel ratio changes, while the use of ethanol confirms compatibility with this fuel. Chapter 7 provides a summary of results for each target country. 


\section{Light-Duty Vehicle Emissions Standards and Fleet Profiles in Study Countries}

There are numerous public sources that provide compilations of emissions regulations across the world [e.g., the Continental Automotive global emissions regulations document (Continental Automotive 2019) or the Delphi Worldwide Emissions Standards document (Delphi Technologies 2020)]. Also, the annual reviews published by SAE International (SAE) by Corning, Inc. were consulted for further references (Joshi 2019). However, these sources are focused on the most recent emissions standards only. Using these as well as other sources (ICCT 2020; Transport Policy n.d.; DieselNet 2020), we compiled Figure 3, showing the standard met in each country over the past approximately three to four decades. Figure 4 shows the approximate equivalent U.S. emissions control standard level for the study countries.

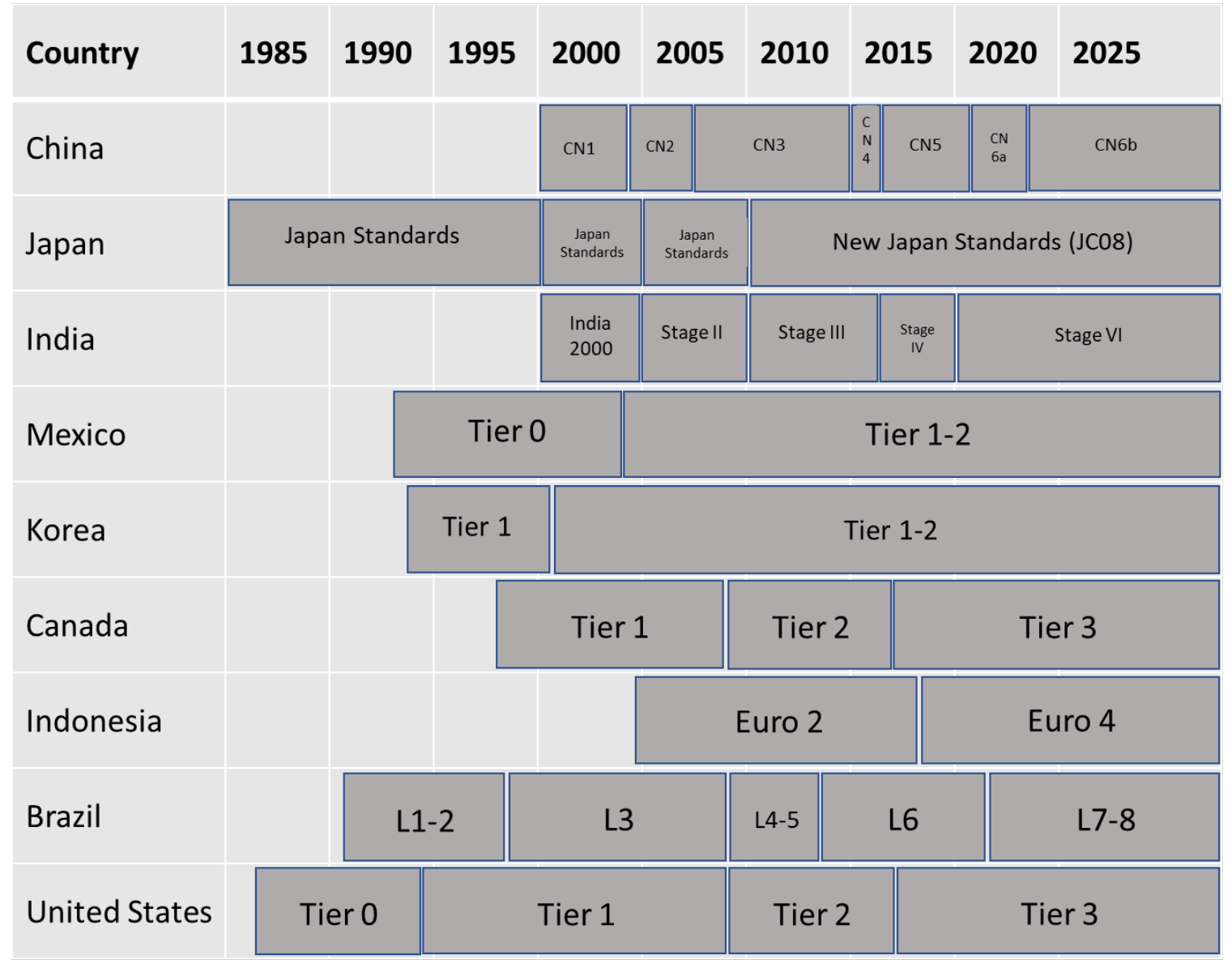

Figure 3. Emissions standards over time for the study countries, plus Brazil and the United States 


\begin{tabular}{|c|c|c|c|c|c|c|c|c|c|}
\hline Country & 1985 & 1990 & 1995 & 2000 & 2005 & 2010 & 2015 & 2020 & 2025 \\
\hline China & \multicolumn{3}{|c|}{ No Reg. } & \multicolumn{2}{|c|}{$\sim$ Tier 0} & Tier 1 & \multicolumn{3}{|c|}{$\sim \operatorname{Tier} 2$} \\
\hline Japan & \multicolumn{3}{|c|}{$\sim$ Tier 0} & \multicolumn{2}{|c|}{$\sim$ Tier 1} & \multicolumn{4}{|c|}{ Tier 2} \\
\hline India & \multicolumn{3}{|c|}{ No Reg. } & Tier & \multicolumn{2}{|c|}{ Tier 1} & \multicolumn{3}{|c|}{$\sim$ Tier 2} \\
\hline Mexico & \multicolumn{2}{|c|}{ No Reg. } & \multicolumn{2}{|c|}{$\sim$ Tier 0} & \multicolumn{5}{|c|}{$\sim \operatorname{Tier} 1 / 2$} \\
\hline Korea & \multicolumn{2}{|c|}{ No Reg. } & Tier $1 / 0$ & \multicolumn{6}{|c|}{ Tier $1 / 2$} \\
\hline Canada & \multicolumn{3}{|c|}{ No Reg } & \multicolumn{2}{|c|}{ Tier 1} & Tier 2 & & \multicolumn{2}{|c|}{ Tier 3} \\
\hline Indonesia & \multicolumn{3}{|c|}{ No Reg. } & & \multicolumn{3}{|c|}{$\sim$ Tier 1} & \multicolumn{2}{|c|}{$\sim$ Tier 2} \\
\hline Brazil & $\begin{array}{l}\text { No } \\
\text { Reg. }\end{array}$ & \multicolumn{2}{|c|}{ Tier 0} & \multicolumn{2}{|c|}{$\sim$ Tier 1} & \multicolumn{4}{|c|}{$\sim$ Tier 2} \\
\hline United States & \multicolumn{2}{|c|}{ Tier 0} & \multicolumn{3}{|c|}{ Ti.er 1} & Tier 2 & & \multicolumn{2}{|c|}{ Tier 3} \\
\hline
\end{tabular}

Figure 4. Approximate equivalence to U.S. emissions standards for the study countries

Given the emissions standards in place over time in the study countries, the next step is to examine the makeup of the existing LDV fleet. The source of these data is theVIO database as of Q4 2019 (with some exceptions as noted below). Brazil and the United States were added to these profiles for comparison. Brazil was chosen because they use anhydrous E27 as their standard gasoline along with options of up to $100 \%$ hydrous ethanol for use in FFVs. The United States was chosen because the standard gasoline is E10, with a large portion of the fleet approved by the EPA to use E15 (RFA 2019).

This chapter includes an evaluation of LDV market size, vehicle fuel type (gasoline, diesel, etc.), fuel system type (carburetion, port fuel injection, etc.), catalyst type, and vehicle age distribution. Additional analyses of vehicle manufacturers for each country, centralization of a country's vehicle production, crossover between study countries and ethanol-compatible markets, and of vehicle models available was less informative, and these results are found in Appendix C. In addition to LDVs and trucks, motorcycles and three-wheeled scooters comprise significant portions of country fleets in India and Indonesia - these are addressed separately in Chapter 5.

\subsection{Data Limitations}

The Experian data has several limitations. The date of first registration is aggregated to a "pre2005 " bin, so it is impossible to tell the specific model year of LDVs older than 2005. The United States and Mexico are exceptions to this limitation where the pre-2005 LDVs are 
described by model year and other attributes. The emissions standards data also has shortcomings as only Euro standards were reported. Vehicles with no emissions standard reported likely include many LDVs certified to EPA standards. Therefore, we researched the background of each country's emissions standards, when those standards were in effect, and when LDVs were first registered in a country.

\subsection{Light-Duty Vehicle Fleet Market Size}

The combined vehicle market of the seven countries of interest (not including Brazil or the United States) is 443 million LDVs. Figure 5 shows that China comprises half of this sevencountry market and has 2.7 times more LDVs than the country with the second-greatest number of LDVs - Japan. Japan has twice the LDVs as the country with the third-greatest number of LDVs-India.

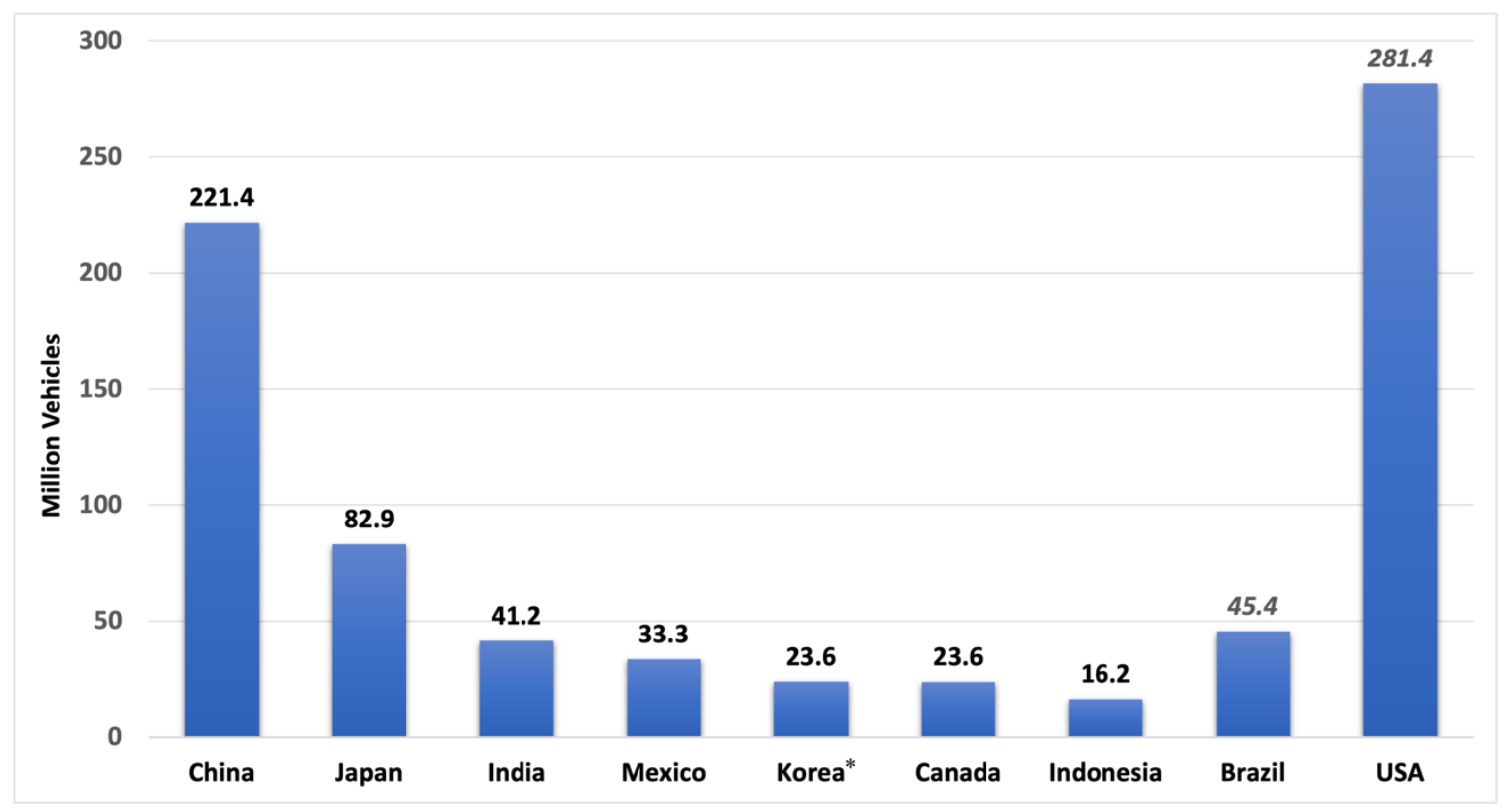

Figure 5. LDVs in operation in seven study countries plus Brazil and the United States

Source: Experian VIO database, Q4 2019.

*South Korean figures are for Q4 2020 instead of Q4 2019 because the data source for South Korea substantially improved in 2020.

\subsection{Vehicle Fuel Types}

Figure 6 shows the breakdown of LDVs by fuel type. Vehicles using diesel, electric, compressed natural gas, liquefied petroleum gas, and hydrogen cannot have any ethanol added to their fuel; therefore, these LDVs are outside the scope of this study. Forty million such LDVs (40\%) are in use in the seven study countries. India, South Korea, and Canada have the largest portions of these LDVs, with diesel being the most popular followed by liquefied petroleum gas.

While the two comparison countries were chosen for the ethanol content in their standard gasoline, their vehicle composition is worth noting. Brazil's gasoline LDVs can use E27, and gasoline LDVs in the United States can use E10 or, since model year 2001, E15. FFVs in these 
two countries can use a range of ethanol - up to 100\% in Brazil and up to E85 in the United States.

After filtering out the 40 million LDVs that use no gasoline, we are left with a population of just over 400 million LDVs in the seven studied countries. These include the fuel categories of gasoline, FFV, hybrid-electric vehicle (HEV), and plug-in hybrid electric vehicle (PHEV). The number of gasoline-using LDVs in each of the study countries is shown in Figure 7. The remainder of this report will refer to this subset of LDVs as "gasoline-using."

When focusing on gasoline-using LDVs, the breakout of LDV populations (Figure 7) remains relatively consistent with the unfiltered LDV populations (Figure 5). China still comprises half the market and is 2.7 times the size of the Japanese market. However, India and South Korea's populations have reduced the number of gasoline-using LDVs the most, meaning that Mexico surpasses India, and Canada surpasses South Korea. Japan accounts for three times the size of the Indian LDV population.

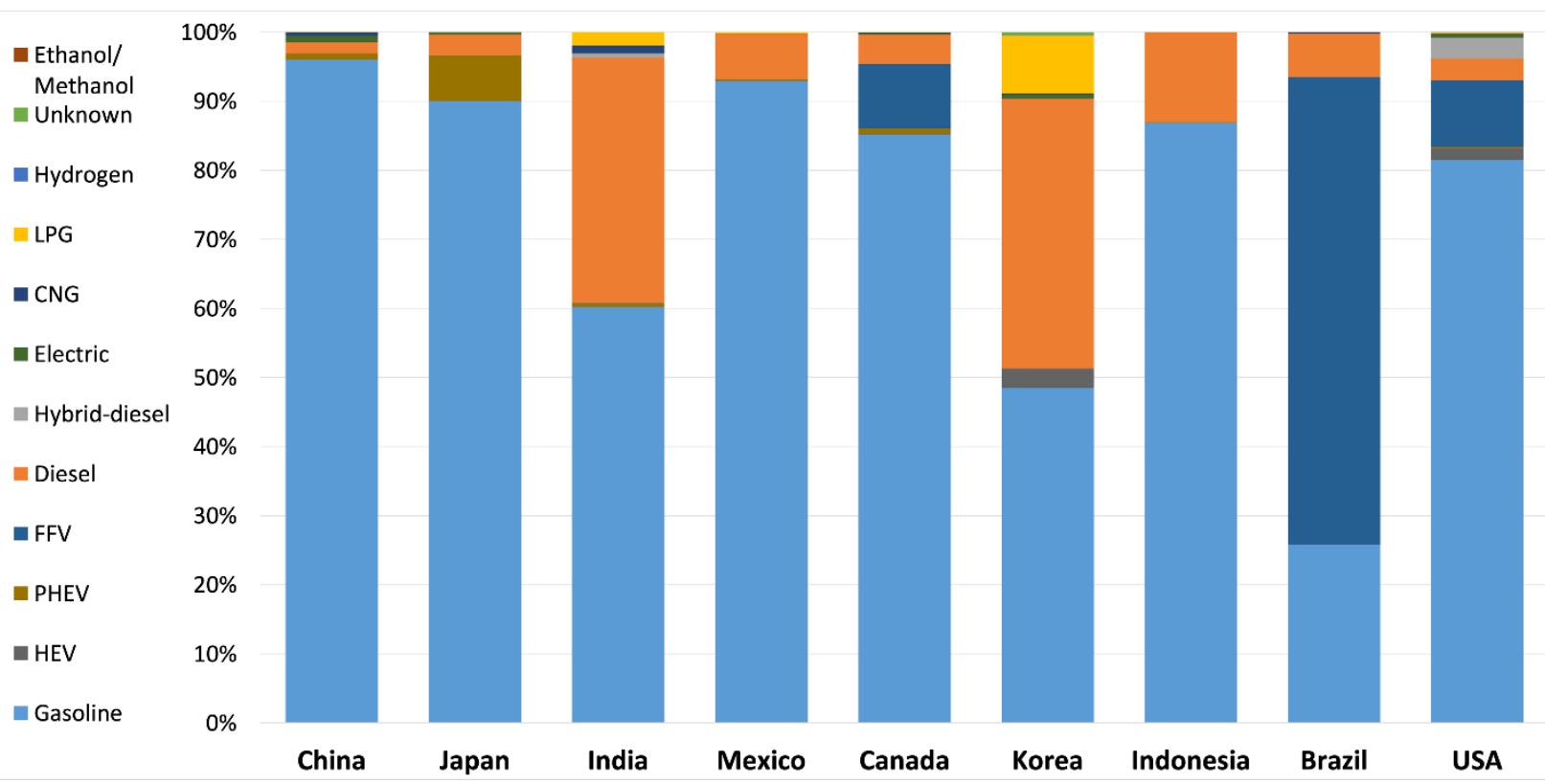

Figure 6. LDVs by fuel type in operation in seven study countries, plus Brazil and the United States

Data Source: Experian VIO database, Q4 2019.

South Korean figures are for Q4 2020 instead of Q4 2019 because the data source for South Korea substantially improved in 2020. 


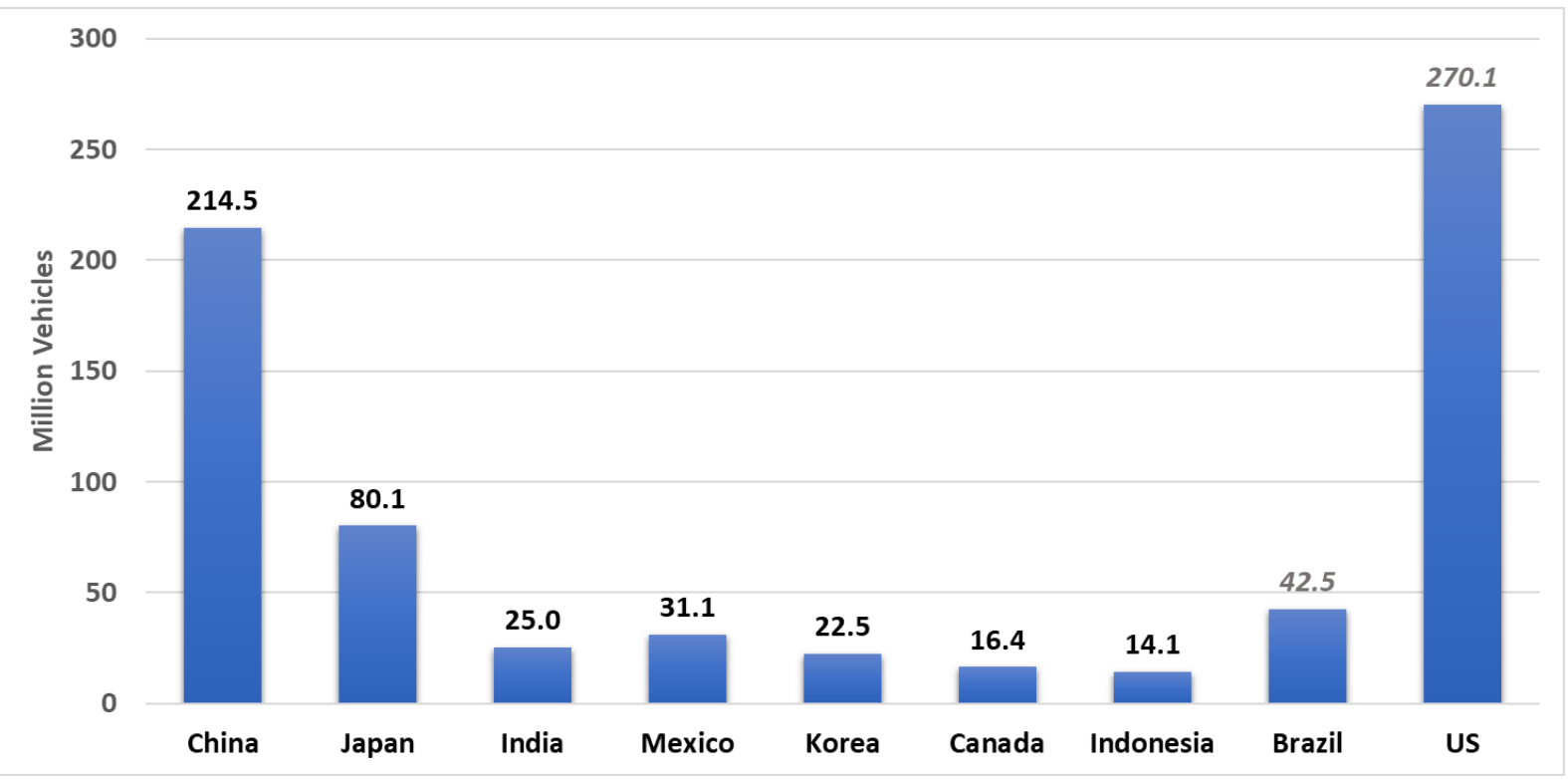

Figure 7. Gasoline-using LDVs in operation in seven study countries, plus Brazil and the United States

Data Source: Experian VIO database, Q4 2019

\subsection{Light-Duty Vehicle Fuel System Types}

The gasoline using LDVs have four primary fuel system types that deliver fuel to the combustion chamber. Carburetors are the oldest of the fuel systems and allow much less precise control of air-fuel ratio than later technologies (Heywood 2018). Fuel injection technology, introducing fuel upstream of the intake valves, then entered the market, including single-point and multipoint variants. Finally, gasoline direct injection (GDI) was implemented to inject fuel directly into the combustion chamber. GDI is the most precise way to control the air-fuel ratio in the combustion chamber and adjust to oxygenates such as ethanol.

Figure 8 shows the percentage of various fuel system types in the fleets of the study countries and Brazil. South Korea, China, and Canada have the largest percentage of GDI LDVs, indicating that between $26 \%$ and $21 \%$ of their LDVs have the most modern capability to adjust to ethanol and optimize combustion. Conversely, India, Indonesia, and Mexico each have around $10 \%$ of their LDVs carbureted, which could stand as a barrier to ethanol use above E10. Likewise, these three countries have small percentages of GDI LDVs. Brazil also has a significant number of carbureted LDVs (8\%), suggesting these are optimized to run on E27.

\subsection{Gasoline-Using Vehicle Catalyst}

LDVs with three-way catalysts utilized closed-loop control of air-fuel ratio and can compensate for fuel oxygen from the blending of oxygenates. Figure 9 shows the percent of vehicle population with the various catalysts in each of the study countries. India, Mexico, and Indonesia have the largest percentage $(\sim 10 \%)$ of LDVs without catalytic converters. In lieu of vehicle age data prior to 2005, this is possibly a sign of old LDVs with materials that are less likely to be compatible with ethanol - and clearly indicates that air-fuel ratio controls are minimal for these vehicles. However, Brazil also has about the same percentage of LDVs without catalytic 
converters, so further investigation is needed. In Brazil's case, older LDVs without air-fuel ratio control may have been modified over time as ethanol blends well above $10 \%$ were introduced. These same countries have substantial portions (India 9\%, Indonesia 6\%, and Mexico 5\%) of two-way open loop converters, which also will not compensate for oxygenates in the fuel. This is contrasted to Brazil, which only has $1 \%$ of its vehicle population with two-way converters.

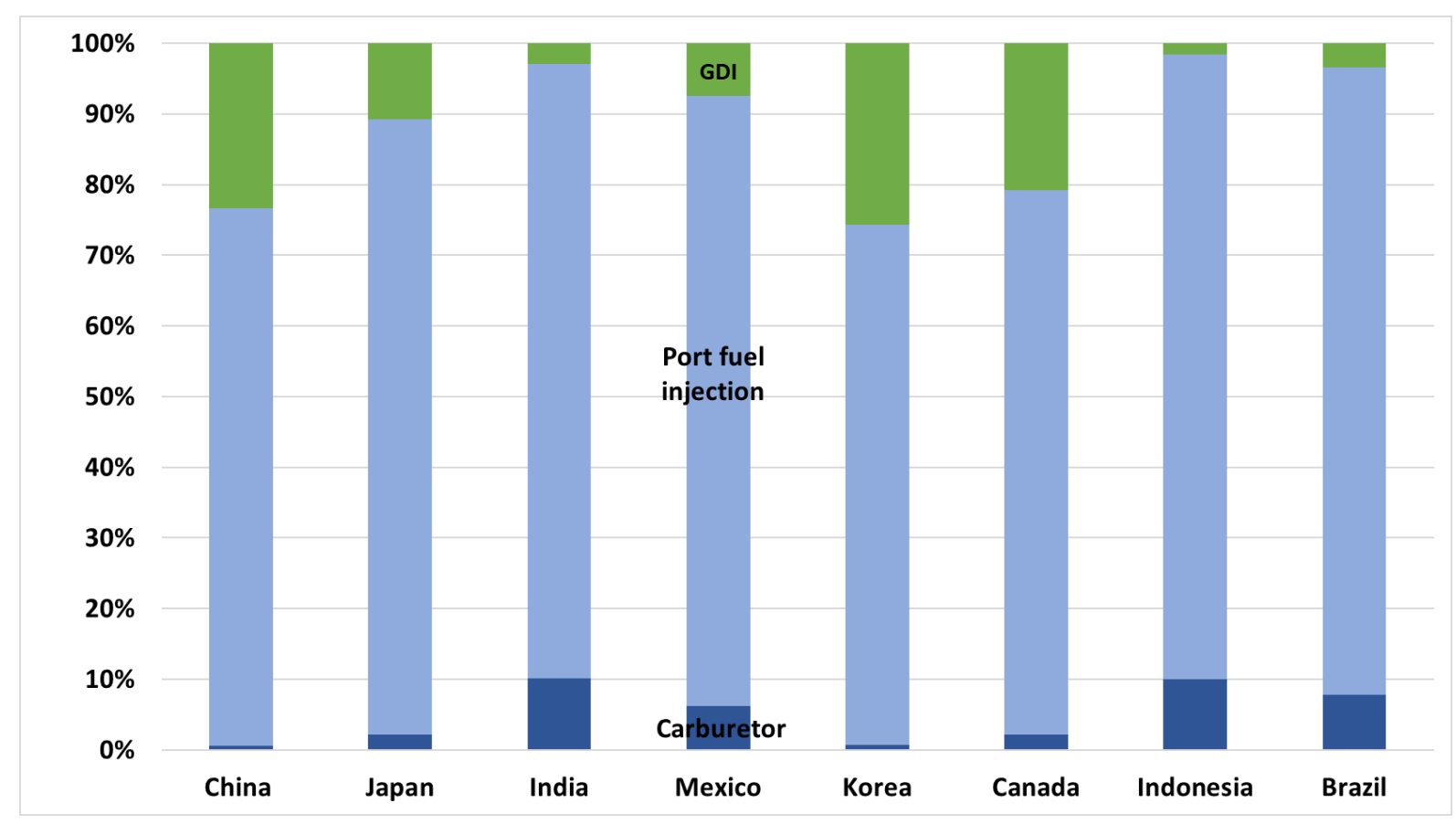

Figure 8. Gasoline-using LDVs by fuel system

Note: Fuel systems in the United States are not available for comparison Data Source: Experian VIO database, Q4 2019 


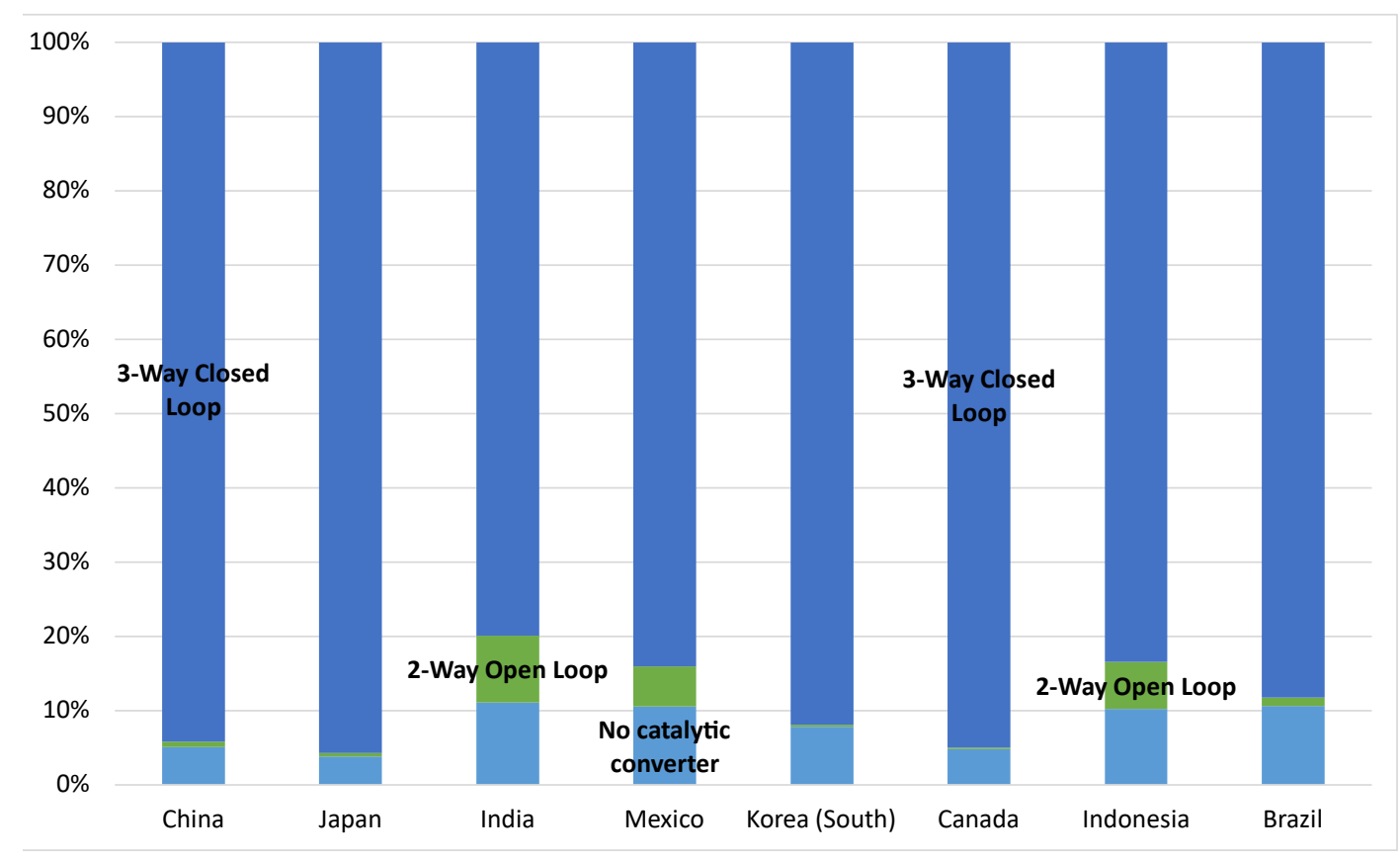

Figure 9. Catalyst type for gasoline-using vehicles

Note: The United States is not included for comparison because the data were unavailable Data Source: Experian VIO database, Q4 2019

\subsection{Vehicle Age Distribution}

Experian data reports the year a vehicle is first registered, regardless of the place of registration. Therefore, the registration date is a reasonable proxy for vehicle age. The data combines all vehicles over 15 years old together, making it impossible to determine the mean age. However, useful statistics can still be determined, as shown in Table 1.

Table 1 shows that China and India have the youngest LDV populations. Canada and South Korea have similar age statistics, with relatively new fleets. Indonesia has many older LDVs at $32 \%$ of the fleet. Mexico has, by far, the oldest fleet, reflected in its median age, high percentage of LDVs more than 15 years old, and low percentage of LDVs less than one year old. 
Table 1. Vehicle Age by Country

\begin{tabular}{|l|c|c|c|}
\hline Country & $\begin{array}{c}\text { Median } \\
\text { Age }\end{array}$ & $\begin{array}{c}\text { \% of Vehicles } \\
\mathbf{2 1 5} \text { years } \\
\text { (Pre-model year } \\
\text { 2005) }\end{array}$ & $\begin{array}{c}\text { \% of Vehicles } \\
<1 \text { Year }\end{array}$ \\
\hline China & 5 & 2 & 10 \\
\hline Japan & 9 & 20 & 6 \\
\hline India & 6 & 11 & 7 \\
\hline Mexico & 14 & 43 & 5 \\
\hline $\begin{array}{l}\text { South } \\
\text { Korea }\end{array}$ & 8 & 21 & 4 \\
\hline Canada & 8 & 20 & 5 \\
\hline Indonesia & 8 & 32 & 6 \\
\hline Brazil & 9 & 23 & 6 \\
\hline $\begin{array}{l}\text { United } \\
\text { States }\end{array}$ & 8 & 24 & 6 \\
\hline
\end{tabular}

Data Source: Experian VIO database, Q4 2019

\subsection{Vehicle Model Year and Emissions Standard for Study Countries}

\subsubsection{China}

The Chinese vehicle fleet has grown dramatically in the past decade and only $2 \%$ of gasolineusing LDVs are pre-2005 (Figure 10). The CN 2 standard, equivalent to Euro 2, was introduced in 2004. As Euro 2 is roughly equivalent to U.S. Tier 1, from an air-fuel ratio control perspective at least $98 \%$ of the LDVs in China should be compatible with blends up to E15, according to our analysis. Newer vehicles in China are required to meet the CN 6 standard beginning July 1, 2020.

China imports roughly $5 \%$ of new LDVs sold with the balance produced in China (China Association of Automobile Manufacturers, 2021).

Excerpts from two current owners manuals from Volkswagen Group China were reviewed for fueling information and ethanol compatibility. The China Audi owner's manual indicated ethanol allowed up to $10 \%$ blend levels. The China Volkswagen Teramont current model owners manual did not specify allowable ethanol limits. However, information from Volkswagen Group China indicated their LDVs are compatible with E10 Chinese National Standard GB18351-2017. 


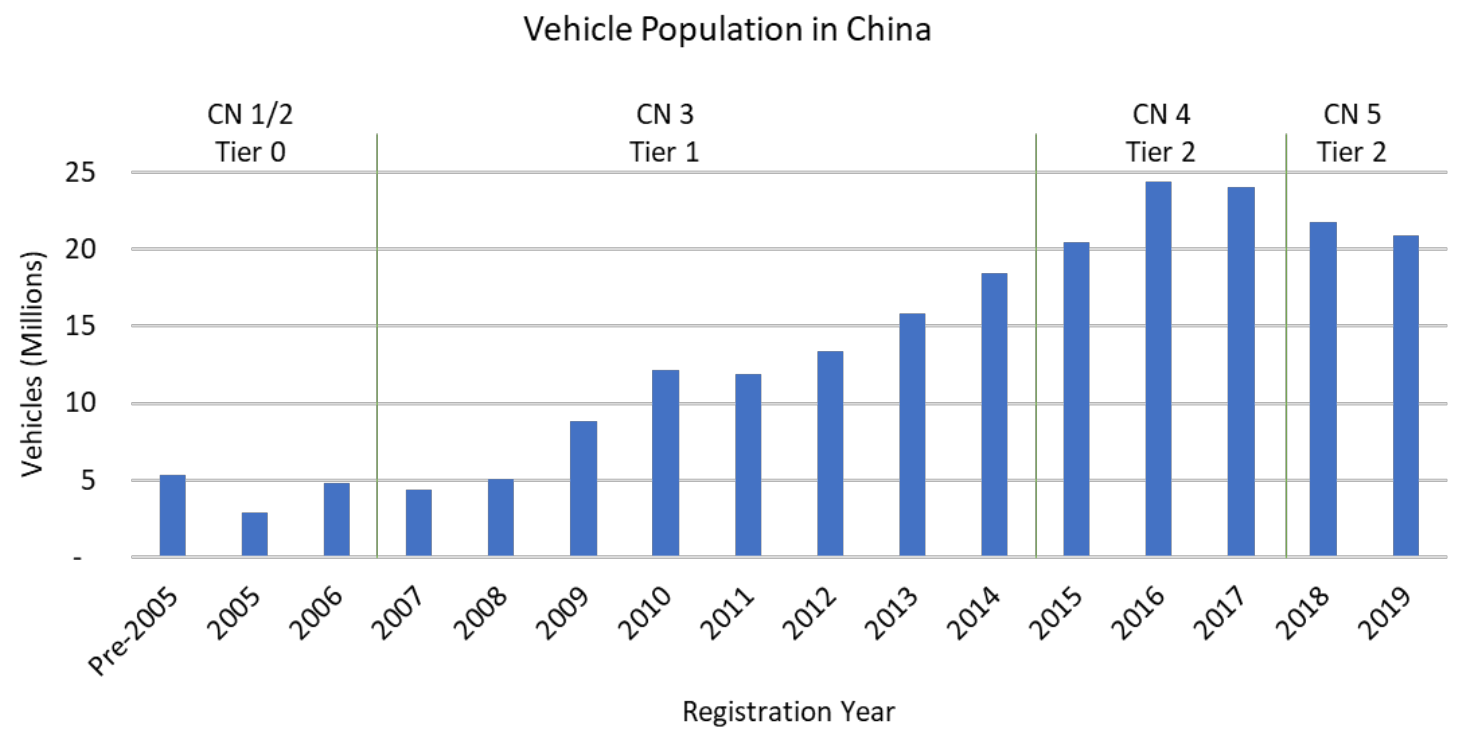

Figure 10. Gasoline-using vehicle age distribution and emissions standards for China

\subsubsection{Japan}

U.S. Tier 2 emissions equivalent requirements cover all new LDVs sold since 2005. However, Japan introduced emissions requirements similar to U.S. Tier 2 in 2000. The model year distribution and emissions standard levels for Japanese LDVs using gasoline are shown in Figure 11. Japan is forcing more stringent emissions regulations and announced adoption of the Worldwide Harmonized Light Vehicles Test Procedure beginning in 2018 and Real Driving Emissions beginning in 2022 (Delphi Technologies 2020; Transport Policy n.d.). Pre-2005 LDVs make up $20 \%$ of the vehicle fleet. Given the relatively high level of emissions-control technologies used in Japan for the past two decades, most of the vehicle fleet should be compatible with blends up to E15, according to our analysis.

Japan produces about 8 million LDVs per year, with more than half going to export (METI 2021). Very few vehicles are imported into Japan.

Toyota Japan has owners manuals available to the public through its website Owner Support menu. The Toyota Camry, model years 2017-2021; Corolla, model years 2020-2021; Prius, model years 2018-2020; and Vitz, model years 2017-2018 manuals indicated that no more than $10 \%$ ethanol should be used. The Pixis Epoch, model years 2017-2020; Pixis Joy, model years 2016-2020; Pixis Space, model years 2011-2013; Pixis Truck, model years 2014-2020; and Prius Alpha Hybrid, model years 2012-2020 manuals do not specifically mention ethanol and only state that gasoline is acceptable (Toyota Motor Corp. 2021). 


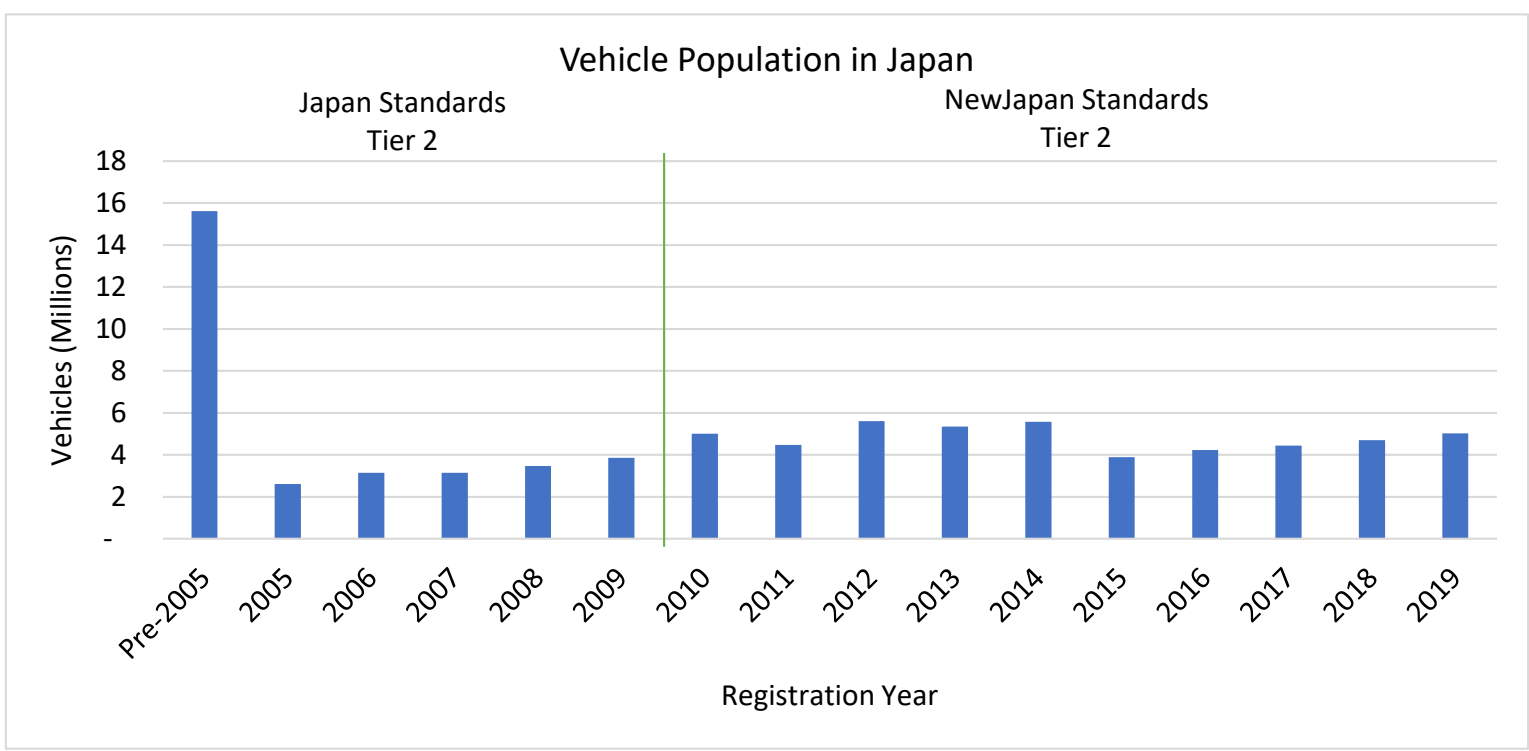

Figure 11. Gasoline-using vehicle age distribution and emissions standards for Japan

\subsubsection{India}

In 2003, India implemented the Bharat standards, which parallel the Euro standards, with Bharat Stage II (BS II) coming into effect in 2005 (Figure 12). As BS II is similar to the Euro 2 emissions standard and roughly equivalent to U.S. Tier 1, these and newer LDVs should be compatible with blends up to E15, according to our analysis. Pre-2005 LDVs make up 15\% of the gasoline using LDV fleet. Around 9\% have two-way, open-loop emissions-control systems that do not control air-fuel ratio. These LDVs are highly likely to be compatible with E10 blends.

India moved from the BS-IV level to the BS-VI level in April 2020 - essentially skipping the originally planned BS V level (Transport Policy n.d.). Currently, 6.6\% of India's LDV population is registered under the BS-VI standard, which is similar to Euro 5 (Continental Automotive 2019).

Indian vehicle makers produce nominally 4 million LDVs per year, of which roughly $18 \%$ are exported (Society of Indian Automobile Manufacturers, 2021).

Maruti was identified as the largest automotive manufacturer in India. Maruti owners manuals were accessed through their website (Maruti Suzuki India Limited n.d.). Evaluations of the popular models specifically built for the Indian marketplace and identified as having a high population in the fleet through the Experian VIO database, included the Celerio, Dzire, Alto 800, Swift, and Wagon R. Owners manuals for these five models all include guidance that use of up to $10 \%$ ethanol is allowable. Additionally, the Dzire, Alto 800, and Wagon R models specify $15 \%$ MTBE is allowed. The Celerio and Swift models note a 5\% methanol allowance. One limitation with the Maruti models was the model year was not provided, and the owner's manual did not specify a copyright date. However, the manuals were noted as most recent version when accessing through the website.

Hyundai India also provided access to owners manuals for the high population models identified through the Experian VIO database as the 2019 Grand i10 NIOS, 2020 i20, 2020 Verna, and 
2019 Santro Xing. However, the Hyundai owners manuals specify a copyright date allowing a closely related model year, which, in the case of these four Hyundai models, was model years 2019-2020, which were all specified to allow the use of E10.

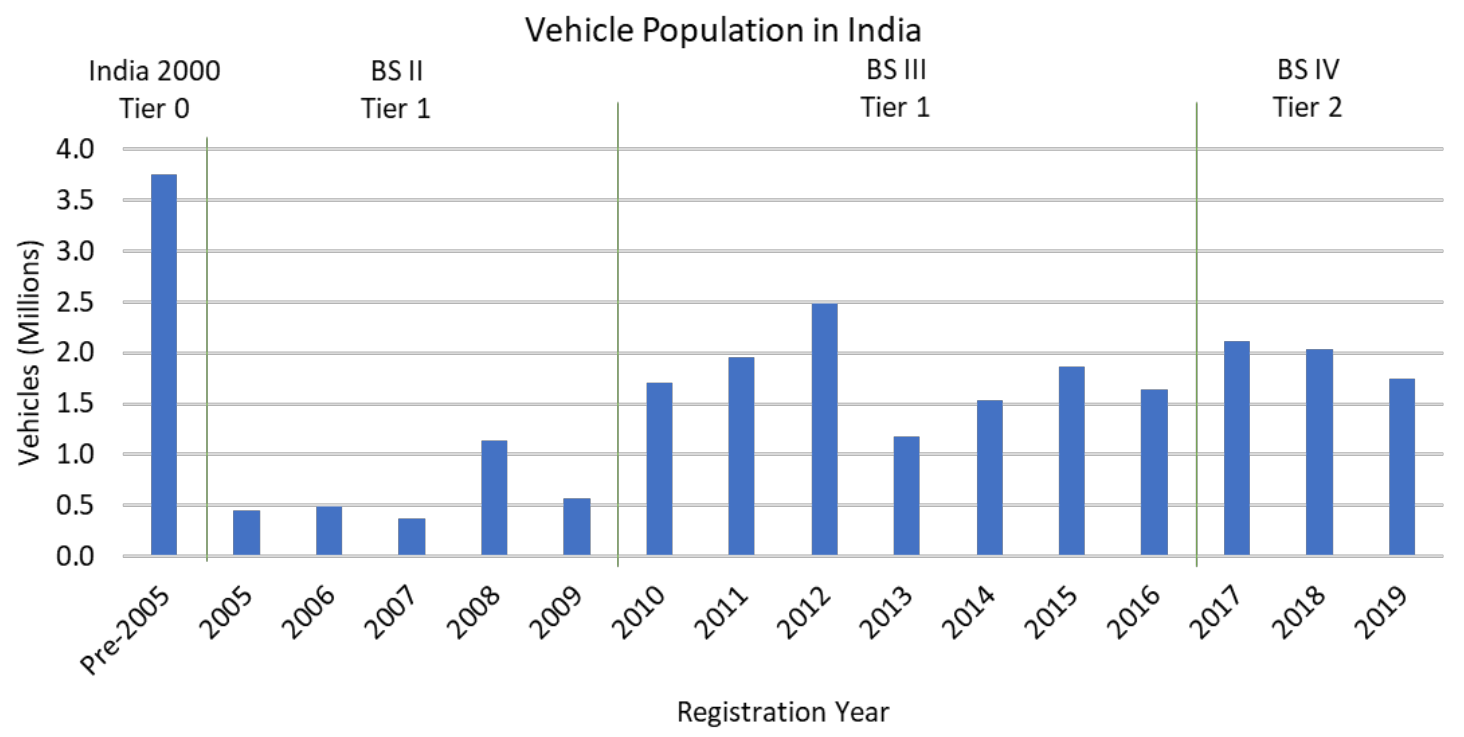

Figure 12. Gasoline-using vehicle age distribution and emissions standards for India

\subsubsection{Mexico}

Mexico has the oldest vehicle fleet of the study countries, with $43 \%$ of gasoline-using LDVs manufactured before 2005 (Figure 13). While the Mexican used-vehicle market includes many LDVs imported from the United States, the data in Figure 13 are tied to registration years in the first country of registration, and used LDVs imported from the United States are included.

Prior to 1993, Mexico did not regulate LDV emissions. Mexico used the U.S. Tier 0 emissions standard beginning in 1993 through 2003 - as can be seen by comparing emissions levels in Figure 4. Since 2004, Mexican emissions standards are a mix of the EPA Tiers 1 and 2, and Euro 3 and 4 standards. Manufacturers can choose to comply with emissions limits based on either the U.S. or European standards (Transport Policy n.d.). While it seems unlikely that U.S., European, and Asian vehicle makers were selling Tier 0 technology LDVs in Mexico by the late 1990s, the Experian database shows nearly $15 \%$ of LDVs in Mexico are not equipped with three-way emissions control catalysts (pre-Tier 0 LDVs). Vehicles without three-way catalysts would not have met U.S. Tier 0 emissions standards. The number of pre-1993 LDVs meeting no emissions regulation aligns closely with the nearly $15 \%$ of LDVs not equipped with a three-way emissionscontrol catalyst, suggesting this population lacks closed-loop fuel control.

As we anticipate all LDVs globally to have a high probability of compatibility with E10, we also conclude that the vehicles in Mexico are compatible with E10. The 2004 and newer vehicles having Tier 1 emissions technology level should be compatible with blends up to E15, according to our analysis. 


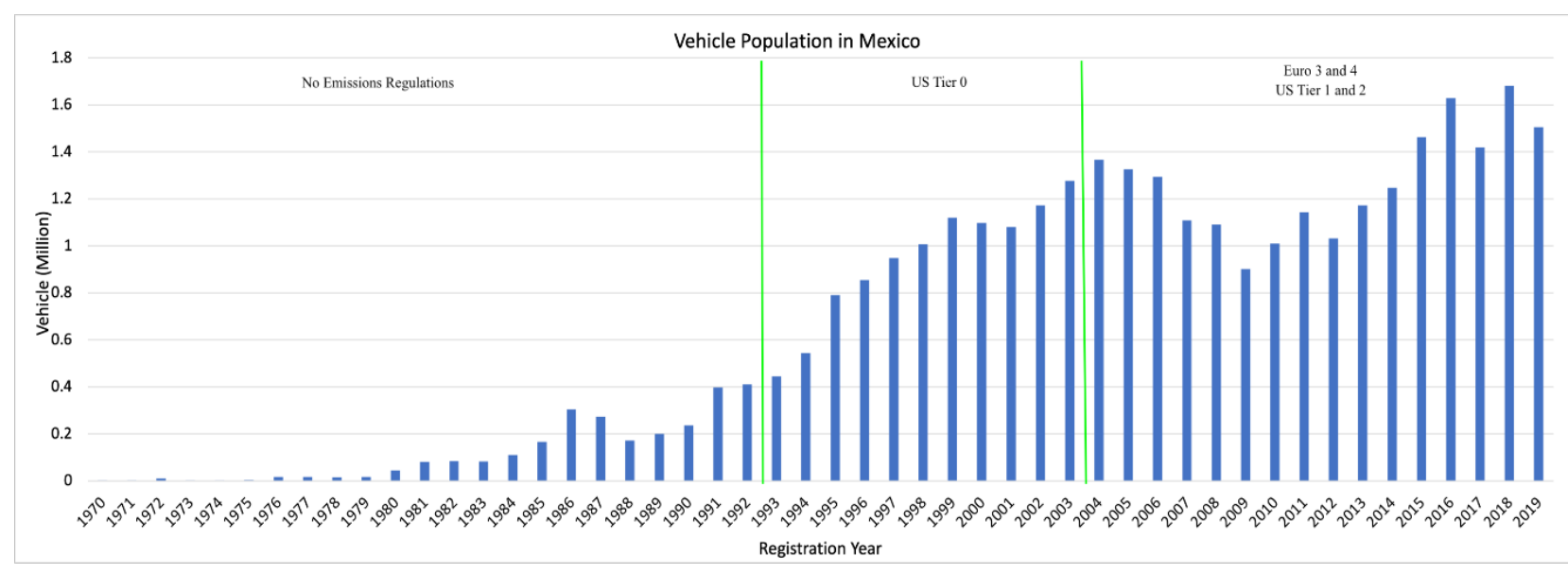

Figure 13. Gasoline-using vehicle age distribution and emissions standards for Mexico

Note: Mexico and the United States are the only countries where the "pre-2005" data are not aggregated

Mexico produces nominally 3.7 million LDVs per year, of which $90 \%$ are exported. Mexico also imports about 900,000 new LDVs and 150,000 used LDVs per year (U.S. International Trade Administration 2020).

Based on an owners manual search, Toyota Mexico provided guidance for several models specific to the Mexican market. The following models were stated as allowing the use of E10: 2016-2019 Yaris, 2019 C-HR, 2017-2019 Hilux truck, and the 2019 RAV4. The following models were specified to allow E15: 2018 RAV4, 2017-2019 Camry, 2018-2019 Corolla, 2018 Highlander, 2018-2019 Land Cruiser, 2018-2019 Sienna, and 2018-2019 Tacoma trucks (Toyota 2016; Toyota MX 2021).

In addition, the USGC Mexico office provided a detailed assessment of owners manuals fuel recommendations for new LDVs sold in Mexico from 2005-2019. The analysis included 309 vehicle models over the 15 model years. For all model-and-year combinations, ethanol was not mentioned, or blends of E10 or higher were approved (for 215 model-and-year combinations, the owners manuals could not be obtained).

\subsubsection{South Korea}

South Korea adopted emissions standards equivalent to U.S. Tier 1 in 1994 and standards similar to U.S. Tier 2 in 2001. Pre-2005 LDVs make up 21\% of the gasoline-using fleet (Figure 14). Current gasoline vehicles are subject to California's nonmethane organic gases Fleet Average System (FAS). In the FAS, vehicle makers can choose one of four standards, each with different levels of emissions standards. The standards $1,2,3$, and 4 are functionally equivalent to California's low-emissions vehicle, ultra-low emissions vehicle, super ultra-low emissions vehicle, and zero emissions vehicle, and have been in effect since 2009 (Transport Policy n.d.). Given the high level of emissions control technology for the entire fleet of LDVs in South Korea, these LDVs should be compatible with blends up to E15, according to our analysis.

South Korea nominally produces 4 million LDVs per year and exports about 2.5 million LDVs (Statista 2021a). Most LDVs registered in South Korea were built in South Korea (see Appendix C). Extensive research for South Korean-based manufacturers and owners manuals was unsuccessful and no information was retrieved. 


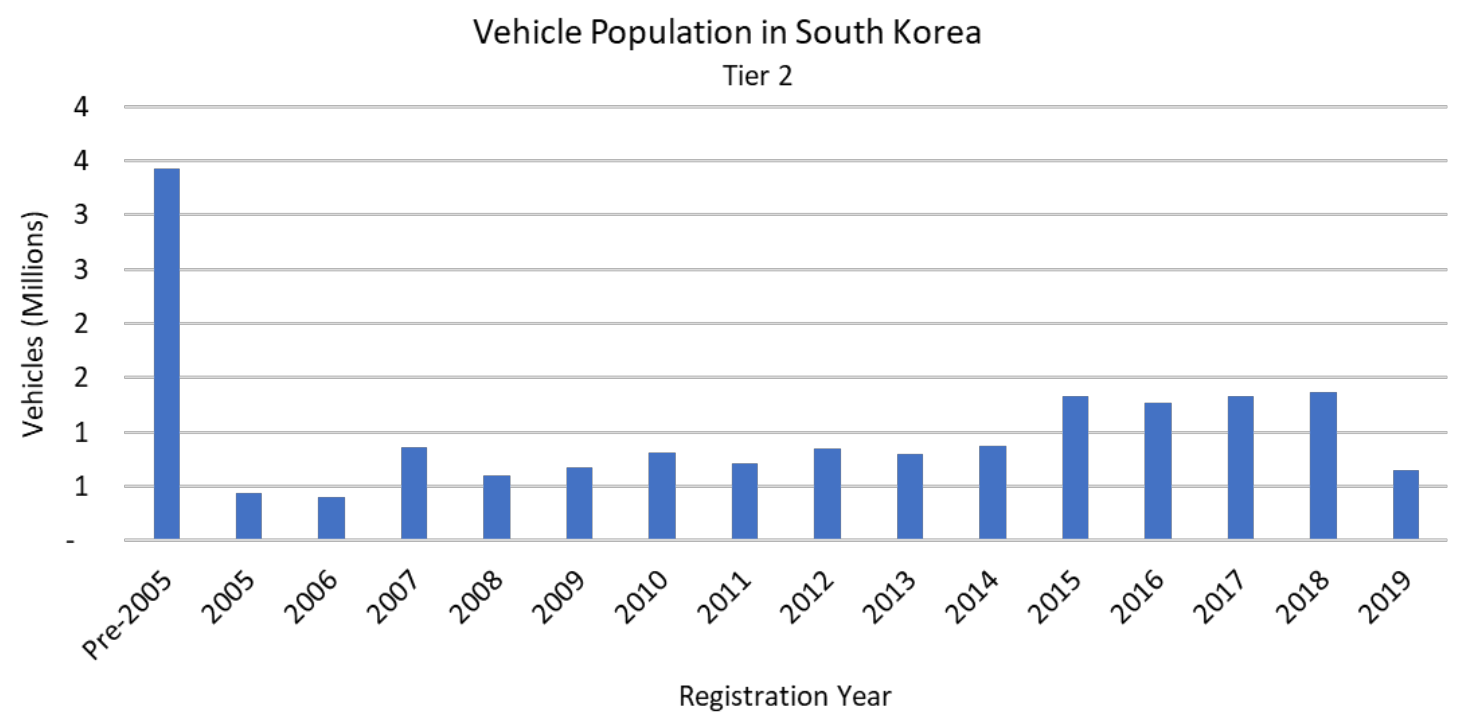

Figure 14. Vehicle age distribution and emissions standards for South Korea

\subsubsection{Canada}

Canada has 16.4 million gasoline-using LDVs, of which about $10 \%$ are FFVs. Canada adopted U.S. Tier 1 (1998) and Tier 2 (2009) standards several years after these were put in place in the United States but adopted Tier 3 at the same time as the United States. While 20\% of LDVs are pre-2005 (Figure 15), given the overall high level of emissions control technology of Canadian LDVs, these vehicles should be compatible with blends up to E15, according to our analysis.

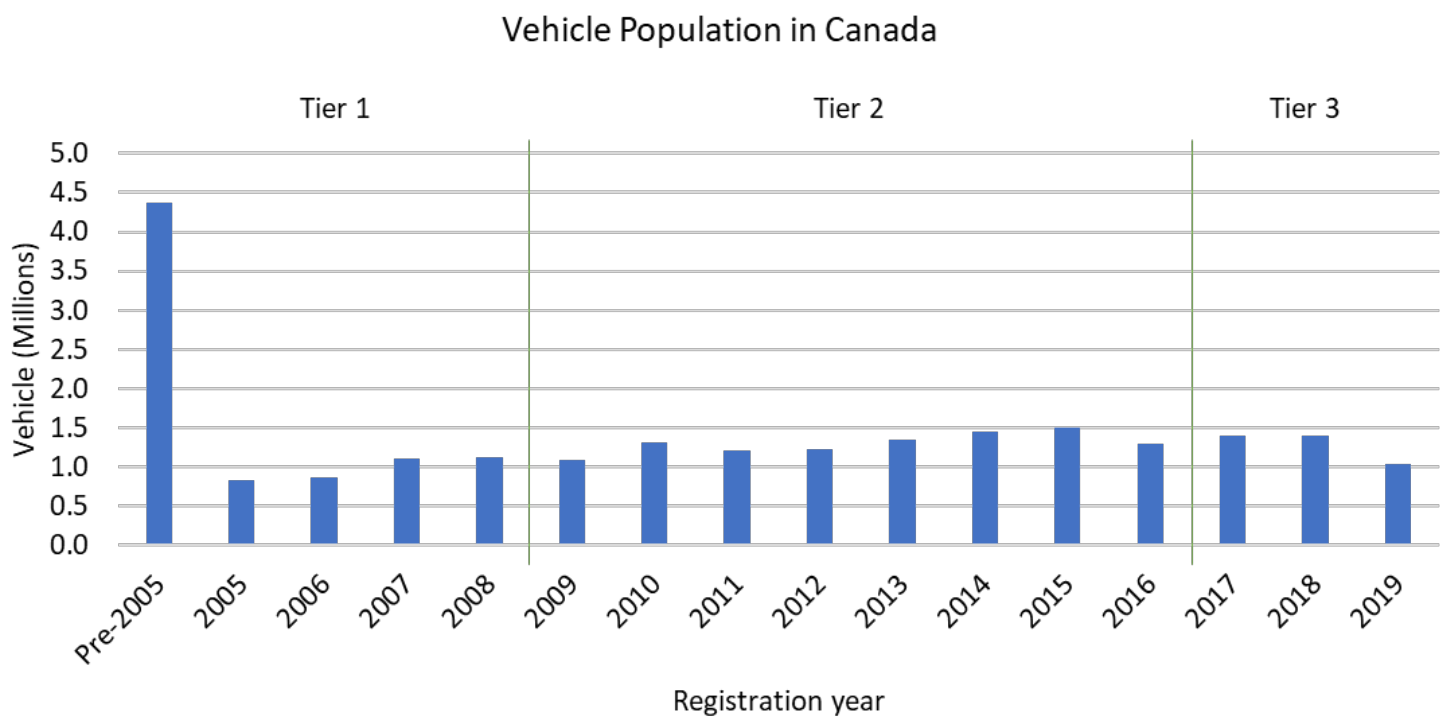

Figure 15. Vehicle age distribution and emissions standards for Canada

\subsubsection{Indonesia}

Indonesia adopted Euro 2 emissions standards in 2005 (Tier 1) and moved to Euro 4 (Tier 2) in 2018 (Figure 16). Currently, 6.8\% of Indonesia's LDV population is registered under the Tier 2 standard (Transport Policy n.d.). Pre-2005 LDVs make up 32\% of the fleet, indicating a large 
fraction of vehicles that were not required to meet any emissions standard. Evaluation of catalyst type shows $15 \%$ of LDVs with either no catalysts or an open-loop, two-way catalyst. Because we anticipate all LDVs globally to have a high probability of compatibility with E10, we also conclude that the LDVs in Indonesia are compatible with E10. The 2005 and newer LDVs with Tier 1 emissions technology level should be compatible with blends up to E15, according to our analysis.

Indonesia produced about one million LDVs per year in recent years and imported about 40,000 vehicles; therefore, most new vehicles sold in Indonesia are produced there (Statista 2021b).

Toyota is the largest automotive manufacturer for the Indonesian market. Toyota Indonesia provides access to all new model year owners manuals (Toyota Astra Co. 2020). The following Indonesian models allowed E10: Toyota SUV C-HR, Camry, Yaris, Agya Hatchback, and FT86. Note that these results are for new model years only (2020-2021).

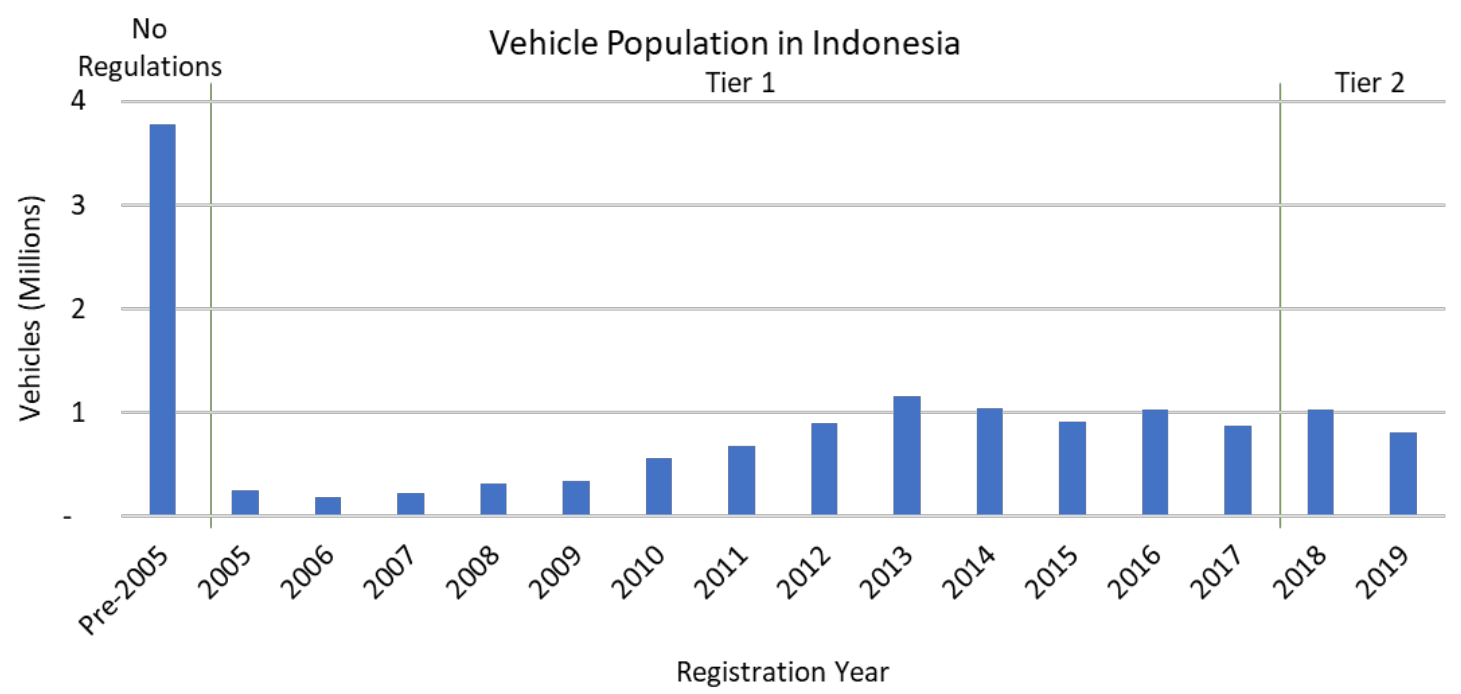

Figure 16. Vehicle age distribution and emissions standards for Indonesia 


\section{Evaluation of Motorcycles and Scooters}

Motorcycles and scooters generally share the same physical/materials and operational/controls as LDVs but, historically, their technology development is delayed from LDVs and trucks. This specifically includes the introduction of fuel injection and emissions controls.

Many older motorcycle and scooter engines were crankcase scavenged, two-stroke engines. There has been concern that ethanol blends may significantly challenge these engines because ethanol may dilute the oil present in the fuel-oil blend that lubricates bearings in the engine crankcase. However, recent research for two-stroke engines with blends in the range of E15 to E20 did not reveal significant durability issues (Loesche 2017; Özer 2019; Yao et al. 2010; Hilbert 2011; Miers and Blough 2013; Jandl et al. 2018; Küüt et al. 2020). Two-stroke engines have been phasing out of production in the last decade because of more stringent emissions requirements (Kamakaté 2009).

Historically, many motorcycle engines were air-cooled with open-loop controls that were calibrated to operate fuel rich (versus stoichiometric) to reduce combustion temperatures for component durability (Knoll et al. 2009). Ethanol blends would shift these engines to operate more fuel lean, potentially raising temperatures and reducing durability. For E10 blends, this fuel-lean effect is likely to be very small but, at some level of oxygenate blending, it could become important for open-loop motorcycle engines.

Motorcycles in Indonesia were unregulated prior to 2006 but met Euro 2 emissions standards beginning in 2006 and Euro 3 standards beginning in 2015. Indian motorcycles have met the BSI standard since 2000, which is like Euro 2, and have been meeting increasingly stringent standards since that time (currently meeting BS-VI which is like Euro 5). Standards through 2010 (BS-III, like Euro 3) were met with various design changes and the use of oxidation (or two-way) catalytic converters (Iyer 2012). In 2014, India adopted the BS-IV standards that forced the use of electronic fuel injection, closed-loop, air-fuel ratio control, and three-way catalysts (ICCT 2014). Based on emissions standards technology and considerations from the United States and Brazilian introduction of ethanol, all motorcycles in Indonesia and India (and globally) have a very high probability of compatibility with E10. Closed-loop control motorcycles, such as those meeting the Euro 4 or equivalent (or higher) standards, should be compatible with blends up to E15, according to our analysis.

Information on the two- and three-wheeled vehicle markets for India and Indonesia were obtained from the MotorcyclesData (McD) database. Each model stored in the McD database is classified by brand, model, category, body type, segments, actual cubic centimeters (cc), and cc class. The goal of analyzing the McD database was to determine the overall fleet makeup and prevalence of motorcycles and scooters in Indonesia and India.

\subsection{Data Limitations}

The McD data set provides registration (Indonesia) and wholesale (India) data for 2012-2020; however, limitations to understanding the study countries' complete populations are apparent. Fuel type, fuel system, and detailed engine information for models of interest were not part of the database. Once a manufacturer and associated model were identified as contributing to a large percentage of that manufacturer's total population, an evaluation of that specific model was 
conducted to determine gasoline type and ethanol compatibility. Additionally, the manufacturer's owners manual was sourced to understand allowable ethanol volume percentage, where available. Exhaust emissions control devices and related technology were not part of the McD data set.

\subsection{Indonesia}

Data for Indonesia were for registrations of motorcycles over a displacement of $50 \mathrm{cc}$, and sales data for vehicles with displacements from $1 \mathrm{cc}-51 \mathrm{cc}$, which do not need to be registered in Indonesia. A comparison of motorcycle registrations from $\mathrm{McD}$ with automobile registrations from the Experian Global VIO database is shown in Figure 17. Total motorcycles registered from 2012-2019 were 54,372,028 units - compared to 8,284,595 registered LDVs. Other sources indicate there are more than 100 million motorcycles in use in Indonesia (ASEANStats 2018; Statista 2020). When averaged across all years in the McD database, motorcycles account for $85 \%$ and automobiles account for $15 \%$ of all registered units in Indonesia.

The McD database captured a total of 58.8 million gasoline-powered units across 28 manufacturers registered between 2012 and 2020. Five major manufacturers contributed $99 \%$ of the total fleet population-Honda, Kawasaki, Suzuki, Yamaha, and Viar. Honda and Yamaha showed the highest population, which accounts for $94 \%$ of the $99 \%$ total fleet makeup for 55.98 million units (Figure 18).

Evaluating the total population in terms of engine size yielded $75 \%$ falling into the $51 \mathrm{cc}-125 \mathrm{cc}$ class, and other percentages as shown in Figure 19. The McD database showed that Honda had the highest population of units registered, 32,699,659, in the $51 \mathrm{cc}-125 \mathrm{cc}$ class, followed by $7,521,098$ units registered in the $126 \mathrm{cc}-250 \mathrm{cc}$ class, with a small remainder falling into the other four displacement categories for registration years 2012-2020.

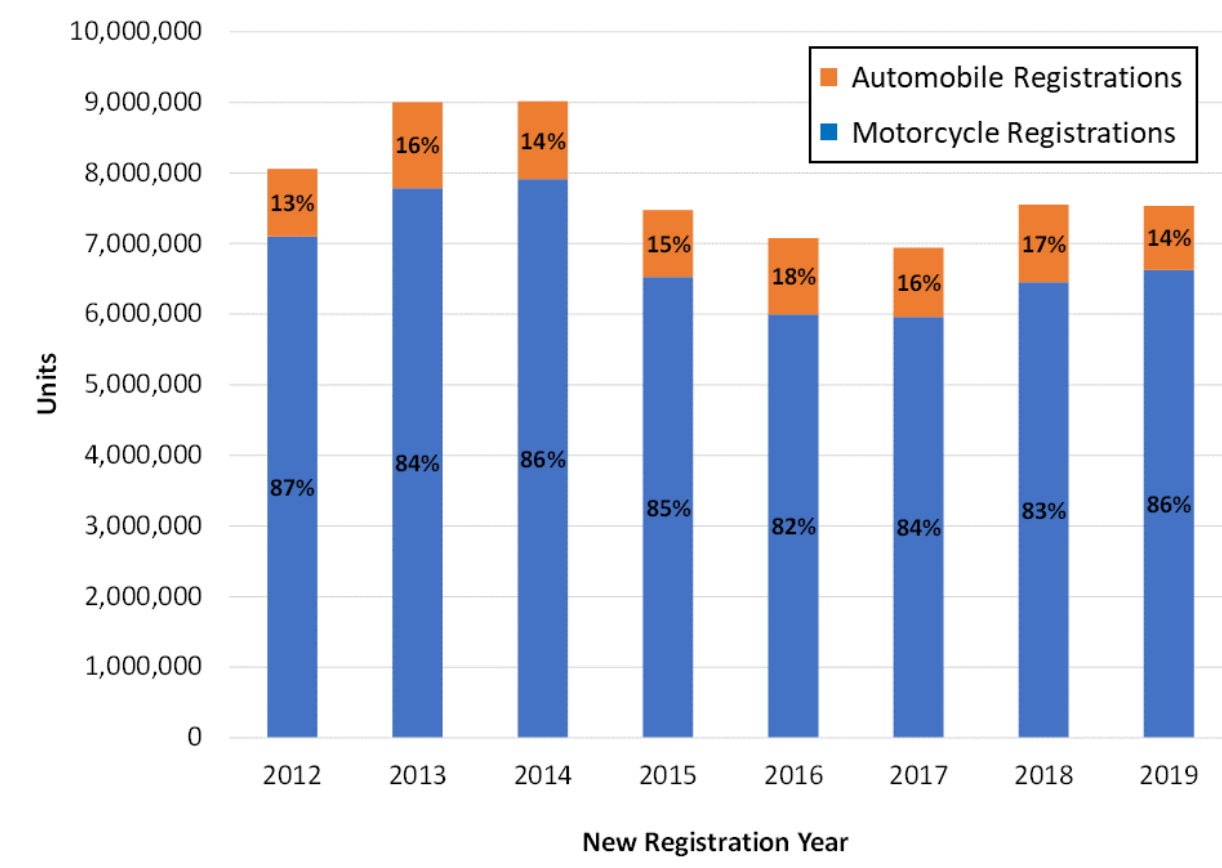

Figure 17. Motorcycle and automobile registrations in Indonesia, 2012-2019 


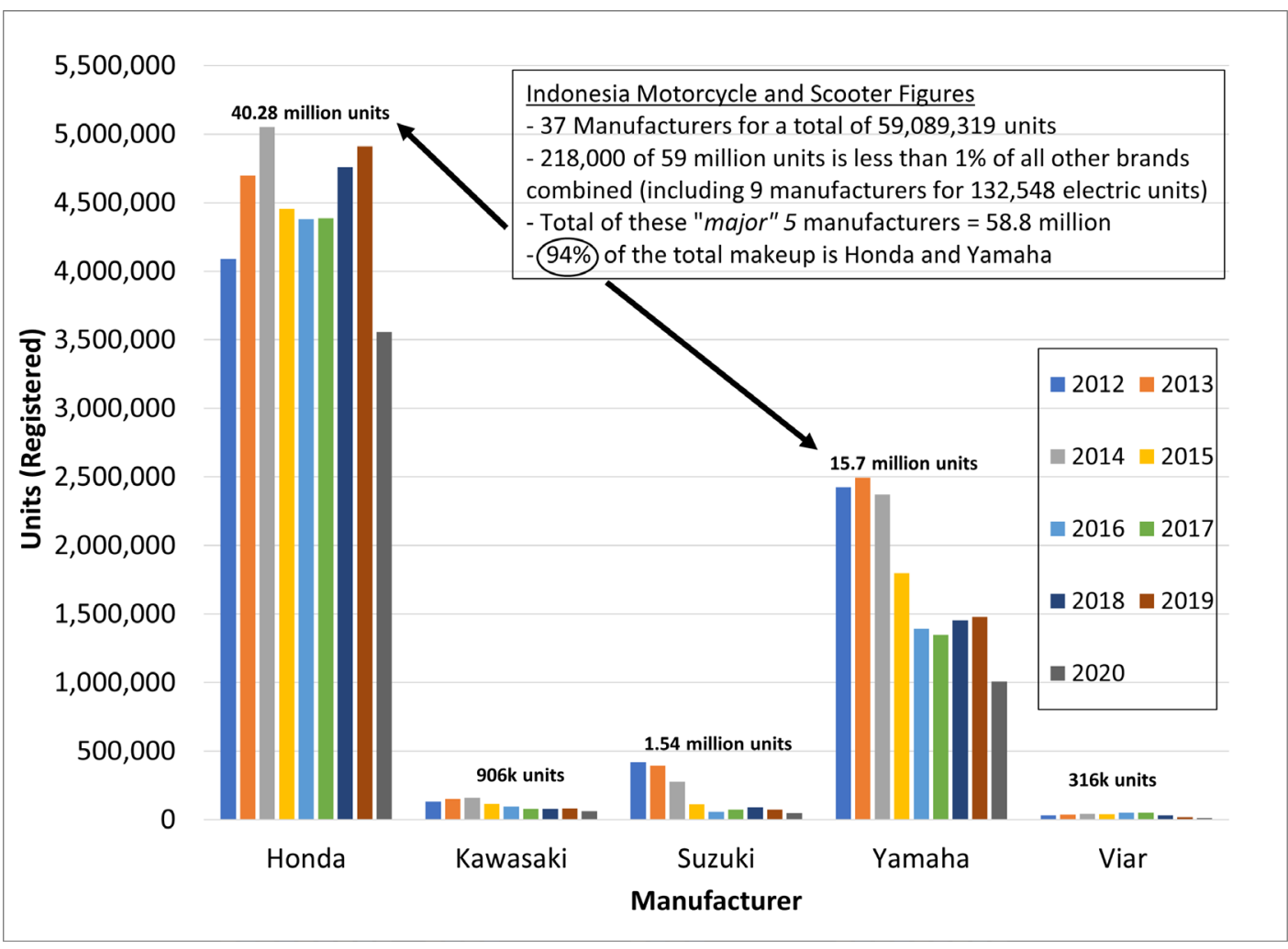

Figure 18. Units registered for the five major motorcycle manufacturers in Indonesia, 2012-2020

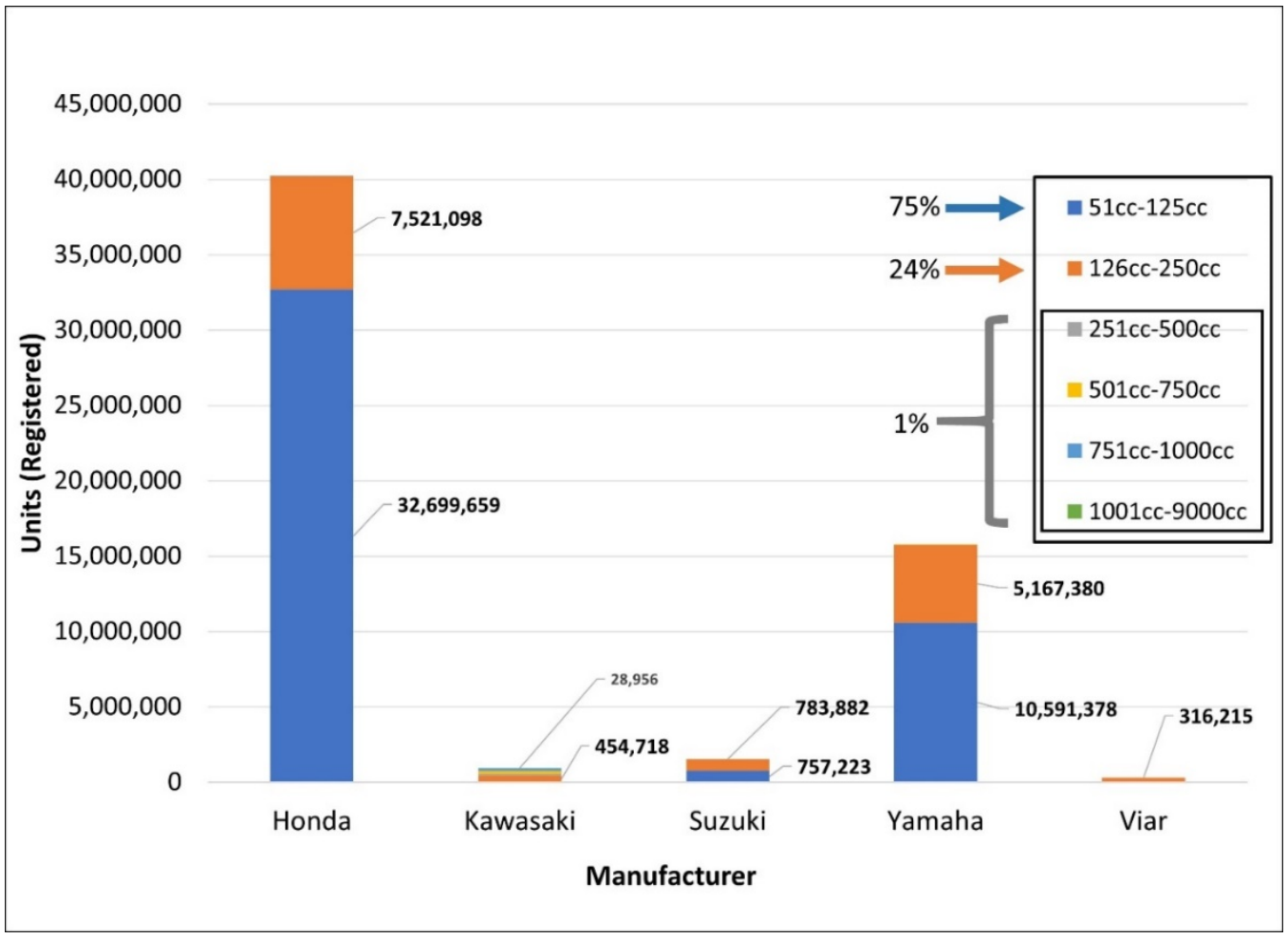

Figure 19. Engine displacements of motorcycles registered in Indonesia from 2012-2020 
An owner's manual survey was conducted for the most popular motorcycle models sold by the five major manufacturers. Honda was the number-one manufacturer and provided access to owners manuals via the web (Honda 2020). Five Honda models (Honda Beat POP eSP, Honda Scoopy, Honda Vario 125 eSP, Honda Super Cub, and Honda Blade 125 FI) were selected as making up a large percentage of the overall Honda population and accounted for 20.9 million of the 40.2 million Honda units covering model years 2015-2018 (Astra Honda 2021; Honda 2020). Evaluation of all Honda model owners manuals indicates allowance of up to $10 \%$ ethanol by volume for model years 2014-2020. Honda's global website for owners manual access was limited to these years.

Yamaha was the second-largest-volume manufacturer; four of its models [Yamaha Fino 125, Yamaha Freego [Freego, Freego (S), Freego S ABS, Yamaha Aerox (Aerox 155, Aerox R155), and the Yamaha MIO] were identified as accounting for 6.8 million of the 15.7 million units registered. Evaluating all owners manuals covering model years 2017-2020, 10\% vol. ethanol is allowed. For the 2017 Yamaha Fino 125 model, models 2015 onward are now being manufactured with flex-fuel technology, allowing up to 85\% vol. ethanol (Yamaha Motor Co., Ltd. 2015; Yamaha 2017). We could not obtain any information on owners manual statements for older motorcycle models. It appears that the $\mathrm{McD}$ database, which goes back to 2012, only covers approximately $60 \%$ of motorcycles in use in Indonesia.

Indonesia implemented Euro 2 emissions requirements for motorcycles in 2005 and Euro 3 in 2015. In other parts of the world, motorcycles with this level of technology are compatible with E10. While some models may be compatible with higher-level ethanol blends, it is difficult to make an assessment based on available information.

\subsection{India}

India vehicle data is based on wholesale tracking (sales to dealers), unlike the Indonesia data that are based on registrations. A comparison of motorcycle and automobile registrations is shown in Figure 20. Total motorcycles registered from 2012-2019 accounted for 145,323,771 units when compared to $27,144,875$ registered automobiles. When averaged across all years, motorcycles account for $81 \%$ and automobiles account for $19 \%$ of all registered units in India (Kamakaté 2009). The total number of motorcycles registered in India was 187 million in 2017 (KnowIndia 2017).

The McD data set captured a total of 159.4 million gasoline-powered units registered between 2012 and 2020, across 22 manufacturers. Ten manufacturers account for 158.9 million of the total motorcycle population-Bajaj, Hero, Honda, Piaggio, Royal Enfield, Suzuki, TVS, Yamaha, Atul Auto Rickshaw, and Mahindra Rickshaw. The distribution of units from these makers is shown in Figure 21. Four of these 10 manufacturers account for $89 \%$ of the total fleet-Bajaj, Hero, Honda, and TVS.

An engine displacement distribution for India is shown in Figure 22, with $82 \%$ falling into the 51 cc-125 cc class, followed by $13 \%$ in the 126 cc-250 cc class, roughly $3 \%$ in the $251 \mathrm{cc}-500 \mathrm{cc}$ class - and the remaining $2 \%$ in the class higher than $501 \mathrm{cc}$. Hero had the largest population, $58,711,075$ units registered, in the $51 \mathrm{cc}-125$ cc class. 


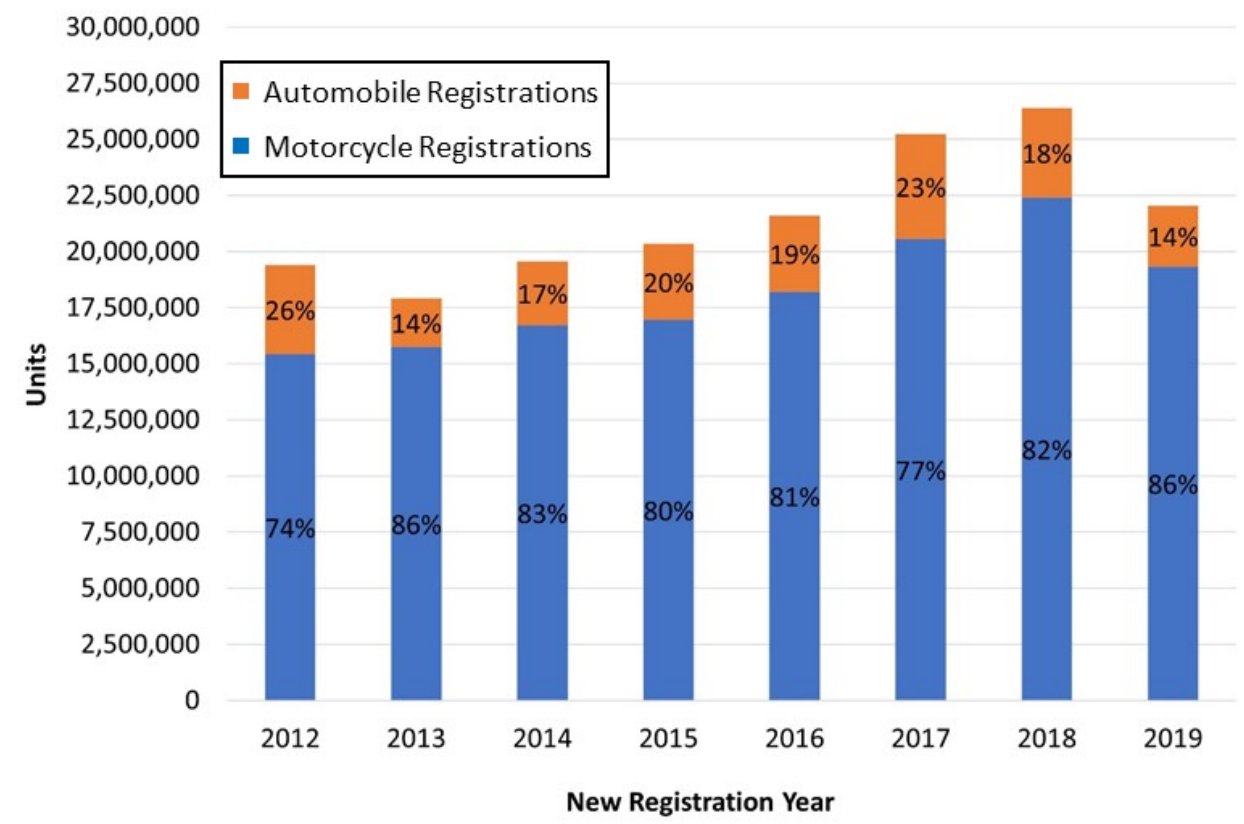

Figure 20. Motorcycle and automobile registrations in India from 2012-2019

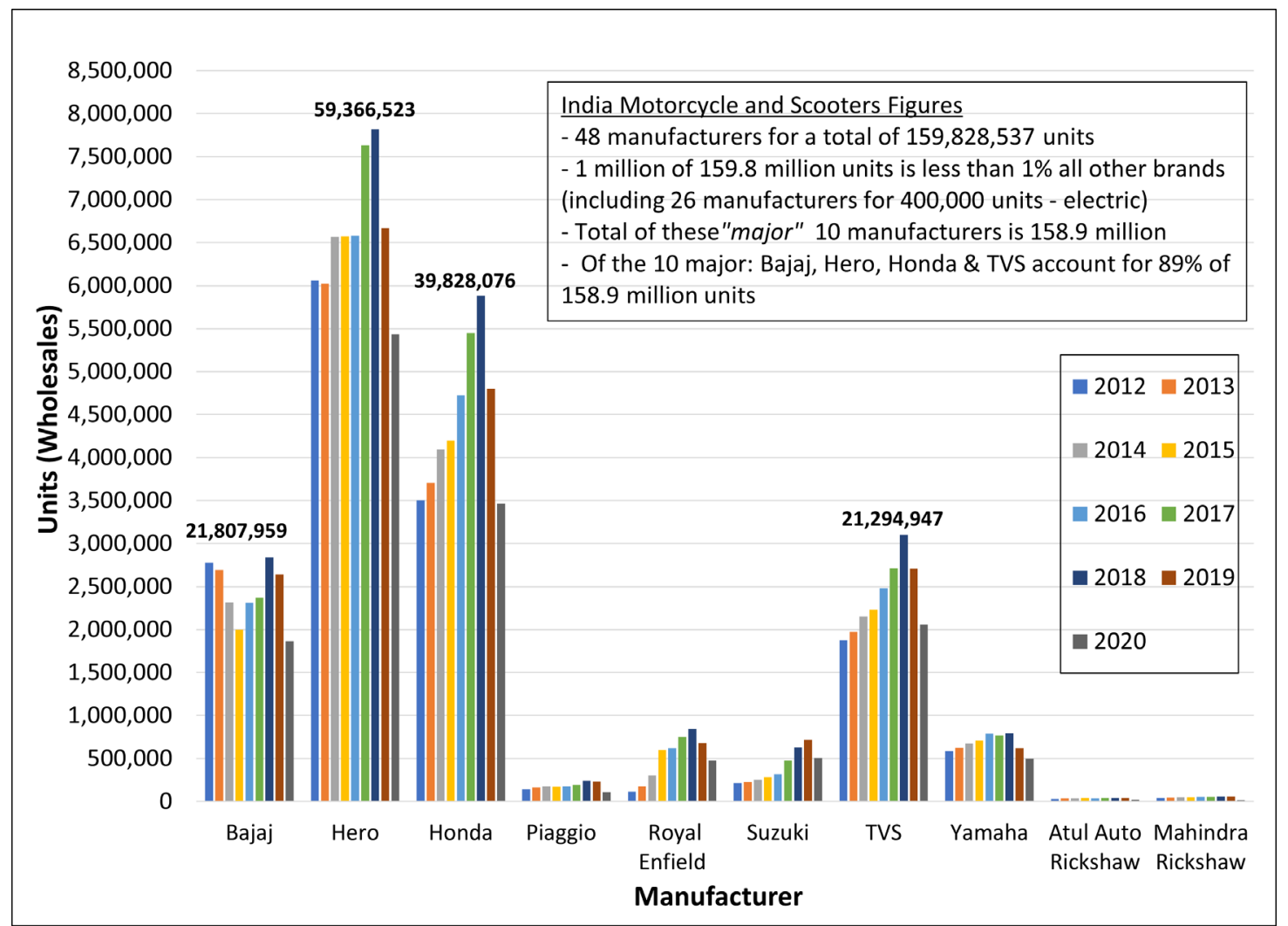

Figure 21. Wholesale numbers for the 10 major motorcycle manufacturers in India from 2012-2020 


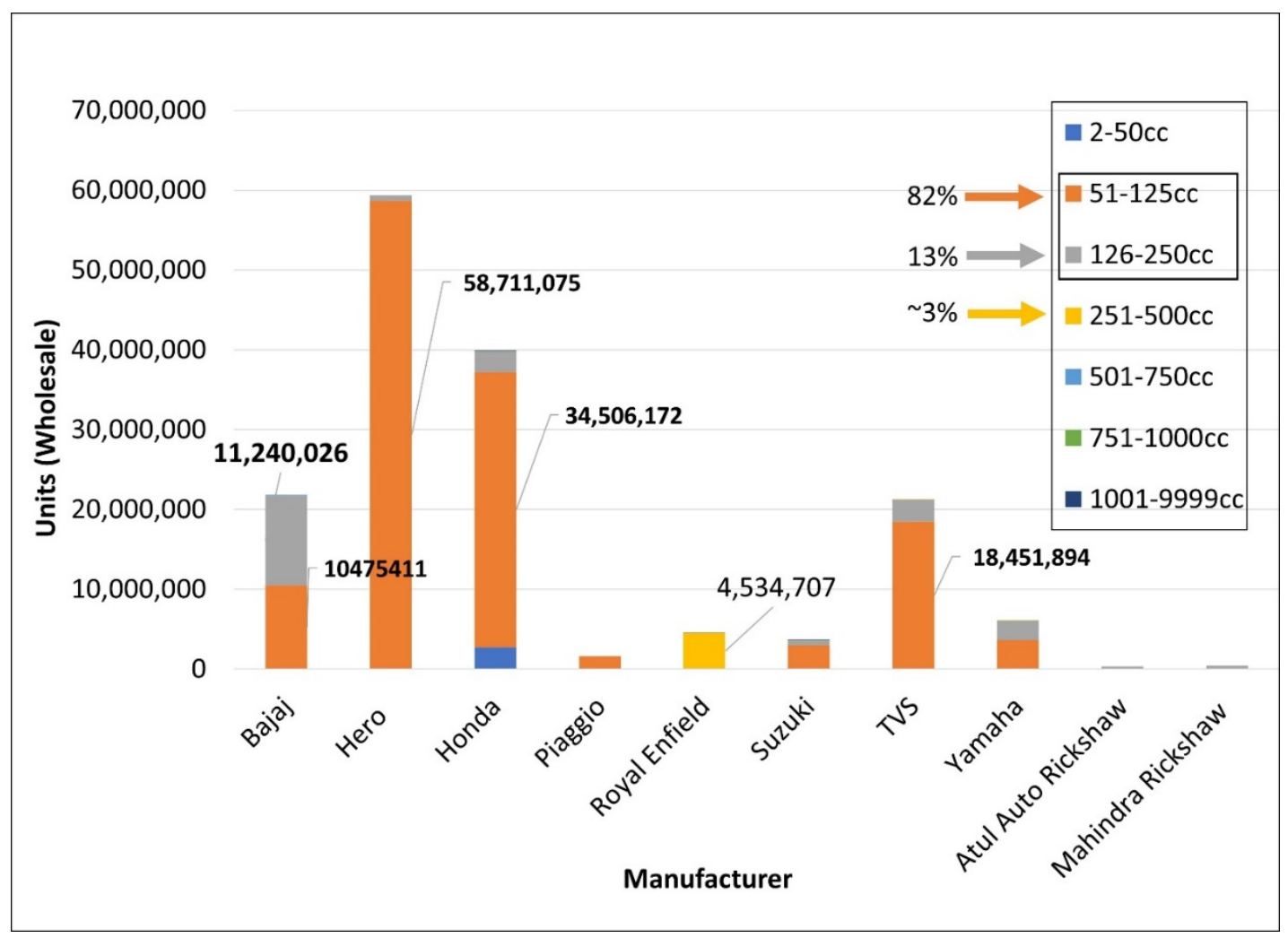

Figure 22. Engine displacements of new motorcycle wholesale units in India from 2012-2020

Of the 10 manufacturers identified as the major contributors to India's motorcycle population, Honda was the number-one manufacturer that provided access to owners manuals. Three Honda models [Honda Active (110 and 125), Honda CB Shine 125, and Honda CB Unicorn] represented a large percentage of the overall Honda population and accounted for 30.6 million of the 39.8 million Honda units in India (Honda 2020a; Honda 2020b). Evaluation of all owners manuals indicate the allowance of E10 for the most recent model year; manuals for other model years were not available.

TVS models account for 21.2 million units of India's 159.8 million total units reported. The TVS XL Super-Moped model was evaluated because of its high number of units (6.7 million). This model accounts for $32 \%$ of the total TVS population. The fuel system is approved for up to $5 \%$ vol. ethanol, following India's BS-VI fuel specifications (TVS Motor Company 2021a; TVS Motor Company 2021b).

Hero manufactured the most units from 2012-2020, according to the McD database, for a total of 59.3 million units and accounting for $37 \%$ of the total population. The 2014 Hero Pleasure, 2015 Hero Duet, 2020 Hero HF Deluxe, and 2020 Hero Splendor owners manuals were evaluated for ethanol blend recommendations. All manuals reviewed call out India's current BS-VI regulation allowing 5\% vol. ethanol (Hero MotoCorp 2021a; Hero MotoCorp 2021b), but do not specifically address ethanol blend suitability.

Summarizing the owners manual survey, the Honda model years evaluated allow up to $10 \%$ vol. ethanol. The TVS Super Moped owner's manual indicated 5\% ethanol, and the Hero models 
reviewed did not specify ethanol compatibility but did refer to the BS-VI fuel standard in which conventional motor gasoline is E5.

Indian motorcycles met the BS I (Euro 1) emissions standard beginning in 2000 and the BS II (Euro 2) in 2005. In other parts of the world, motorcycles meeting these or equivalent standards are considered compatible with E10. While some models may be compatible with higher-level ethanol blends, it is difficult to make an assessment based on available information. Recent model year motorcycles (2014 and newer) are very likely compatible with E15 given that they require closed-loop control to meet emissions requirements. 


\section{Fuels Currently Used in Study Countries}

This section describes fuel markets in the target countries in terms of usage of ethanol and other oxygenates, fuel properties, and fuel regulations or mandates relevant to ethanol.

Fuel sample survey data for ethanol, MTBE, ETBE, and oxygen content for each study country are shown in Table 2. These data come from the 2019 SGS Global Fuel Survey that encompasses various sample locations and fuel types around each study country. Samples taken typically spanned each grade of fuel available (e.g., regular, premium, premium plus); however, sample locations and sample numbers varied between countries and may not incorporate every grade and type of fuel presently available. Fuel survey data was evaluated to determine current ethanol blend levels as well as the presence of other oxygenates that could be replaced by ethanol. Other fuel properties that might point to unique aspects of the country's fuel markets are shown in Table 3.

\subsection{China}

Ethanol is currently being used as E10 in China. In 2019, the estimated average ethanol blend level was $2.5 \%$ and was expected to reach $4 \%$ by the end of 2020 (Somwanshi, Singh, and Kesavan 2020; Kim 2019). China produced one billion gallons of fuel ethanol in 2019, according to the Renewable Fuels Association (RFA), making it the fourth-largest ethanol producer globally (EIA 2020; RFA 2020). In 2017, China implemented an import tariff on U.S.-produced fuel ethanol that was $70 \%$ by July 2018 (USGC, 2021a). In 2021, there appears to have been a reduction in the tariff to $45 \%$, and some imports of U.S. ethanol to China resumed (Rueters and Lewis 2021). China's National Energy Administration announced a plan for nationwide use of E10 gasoline by 2020 and, in 2018, E10 was available in 12 provinces. Currently, because of COVID-19, insufficient ethanol production capacity, and a decline in national corn stocks, the nationwide E10 mandate plan was suspended but remains in place in 11 provinces. Blend targets for provinces that had already implemented ethanol blends will remain in place. China's annual energy plan includes policies that support a doubling of 2019 ethanol production by 2025 . MTBE was also identified as an oxygenate and octane booster widely in use (DieselNet 2020).

China has adopted national standards for denatured fuel ethanol (GB 18350) and for E10 gasoline (GB 18351). China fuel survey samples were for three grades-regular, premium, and premium-plus. Of the 10 regular gasoline samples, two contained ethanol $(10.17 \%$ vol. and $10.38 \%$ vol.). MTBE was also reported at up to $9.94 \%$ vol. Of the 14 premium fuel samples, four contained ethanol ranging from $9.52 \%$ vol. to $10.52 \%$ vol. MTBE was present at up to $12.6 \%$ vol. in all premium fuel samples not utilizing E10. The three premium-plus samples contained no ethanol; however, MTBE ranged from $12.06 \%$ vol. to $14.1 \%$ vol. Based on properties in Table 3, Chinese gasoline appears similar to other gasolines around the globe, but with very low olefin levels compared to other study countries. 
Table 2. Oxygenates Observed in Survey Gasolines in Study Countries

\begin{tabular}{|c|c|c|c|c|c|c|c|c|c|c|c|c|c|c|c|c|}
\hline & \multirow{2}{*}{\multicolumn{2}{|c|}{$\begin{array}{c}\text { China } \\
\begin{array}{c}\text { GB18351- } \\
2017\end{array}\end{array}$}} & \multicolumn{2}{|c|}{ Japan } & \multicolumn{2}{|c|}{ India } & \multicolumn{2}{|c|}{ Mexico } & \multicolumn{2}{|c|}{ S. Korea } & \multicolumn{2}{|c|}{ Canada } & \multicolumn{2}{|c|}{ Indonesia } & \multicolumn{2}{|c|}{ Brazil } \\
\hline Fuel Standard & & & 220 & $\begin{array}{l}K \\
2012\end{array}$ & IS 27 & :2017 & $\begin{array}{l}\text { NON } \\
\text { CRE }\end{array}$ & $\begin{array}{l}016- \\
2016\end{array}$ & $\begin{array}{r}\text { Notific } \\
2016\end{array}$ & $\begin{array}{l}\text { ion No. } \\
\text { o } 2016\end{array}$ & CGS & $\begin{array}{l}-3.511- \\
16\end{array}$ & $\begin{array}{r}9.33 / K \\
3674\end{array}$ & $\begin{array}{l}\text { /DJM.S } \\
\text { 4/DJM }\end{array}$ & ANP & Jo. 40 \\
\hline Grade & Min & Max & Min & Max & Min & Max & Min & Max & Min & Max & Min & Max & Min & Max & Min & Max \\
\hline $\begin{array}{l}\text { Samples } \\
\text { Low } \\
\text { Reg } \\
\text { Prem } \\
\text { Prem+ }\end{array}$ & & . & & & & 3 & & & & 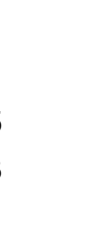 & & $\begin{array}{l}6 \\
6 \\
2\end{array}$ & & & & 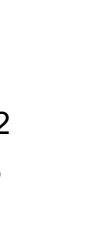 \\
\hline $\begin{array}{l}\text { Ethanol (\% vol.) } \\
\text { Low } \\
\text { Reg } \\
\text { Prem } \\
\text { Prem+ }\end{array}$ & $\begin{array}{l}0 \\
0 \\
0\end{array}$ & $\begin{array}{c}10.4 \\
10.5 \\
0\end{array}$ & $\begin{array}{l}0 \\
0\end{array}$ & $\begin{array}{l}2.47 \\
0.33\end{array}$ & $\begin{array}{l}0 \\
0\end{array}$ & $\begin{array}{l}9.82 \\
9.60\end{array}$ & -- & -- & -- & $\begin{array}{l}-- \\
--\end{array}$ & $\begin{array}{c}9.56 \\
0 \\
0\end{array}$ & $\begin{array}{c}9.79 \\
4.00 \\
0\end{array}$ & $\begin{array}{l}-- \\
-- \\
-- \\
--\end{array}$ & $\begin{array}{l}-- \\
-- \\
-- \\
--\end{array}$ & $\begin{array}{l}24.8 \\
25.3\end{array}$ & $\begin{array}{l}29.3 \\
27.8\end{array}$ \\
\hline $\begin{array}{l}\text { MTBE (\% vol.) } \\
\text { Low } \\
\text { Reg } \\
\text { Prem } \\
\text { Prem+ }\end{array}$ & $\begin{array}{c}0 \\
0 \\
12.1\end{array}$ & $\begin{array}{c}9.9 \\
12.8 \\
14.3\end{array}$ & $\begin{array}{l}0 \\
0\end{array}$ & $\begin{array}{c}0 \\
1.1\end{array}$ & $\begin{array}{l}0 \\
0\end{array}$ & $\begin{array}{l}8.36 \\
1.10\end{array}$ & $\begin{array}{c}1.36 \\
11.45\end{array}$ & $\begin{array}{l}11.86 \\
13.58\end{array}$ & $\begin{array}{c}5.48 \\
9.7\end{array}$ & $\begin{array}{c}11.05 \\
10\end{array}$ & $\begin{array}{l}-- \\
-- \\
--\end{array}$ & $\begin{array}{l}-- \\
-- \\
--\end{array}$ & $\begin{array}{c}1.98 \\
2.12 \\
11.0 \\
0.2\end{array}$ & $\begin{array}{l}3.22 \\
5.96 \\
14.3 \\
5.48\end{array}$ & -- & $\begin{array}{l}-- \\
--\end{array}$ \\
\hline $\begin{array}{l}\text { ETBE (\% vol.) } \\
\qquad \begin{array}{l}\text { Low } \\
\text { Reg } \\
\text { Prem } \\
\text { Prem+ }\end{array}\end{array}$ & $\begin{array}{l}-- \\
--\end{array}$ & -- & $\begin{array}{c}0 \\
3.11\end{array}$ & $\begin{array}{l}6.68 \\
6.44\end{array}$ & $\begin{array}{l}-- \\
--\end{array}$ & -- & $\begin{array}{l}-- \\
--\end{array}$ & -- & -- & $\begin{array}{l}-- \\
--\end{array}$ & $\begin{array}{l}-- \\
-- \\
--\end{array}$ & $\begin{array}{l}-- \\
-- \\
--\end{array}$ & $\begin{array}{l}-- \\
-- \\
-- \\
--\end{array}$ & $\begin{array}{l}-- \\
-- \\
-- \\
--\end{array}$ & $\begin{array}{l}-- \\
--\end{array}$ & $\begin{array}{l}-- \\
--\end{array}$ \\
\hline $\begin{array}{l}\text { Oxygen }(\% \mathrm{~m} / \mathrm{m}) \\
\text { Low } \\
\text { Reg } \\
\text { Prem } \\
\text { Prem+ }\end{array}$ & $\begin{array}{l}0.64 \\
1.36 \\
2.20\end{array}$ & $\begin{array}{l}3.86 \\
3.86 \\
2.53\end{array}$ & $\begin{array}{c}0 \\
0.49\end{array}$ & $\begin{array}{l}1.23 \\
1.11\end{array}$ & $\begin{array}{l}0 \\
0\end{array}$ & $\begin{array}{l}3.64 \\
3.54\end{array}$ & $\begin{array}{l}0.24 \\
2.18\end{array}$ & $\begin{array}{l}2.20 \\
2.52\end{array}$ & $\begin{array}{l}1.45 \\
1.81\end{array}$ & $\begin{array}{l}2.08 \\
1.93\end{array}$ & $\begin{array}{c}3.52 \\
0 \\
0\end{array}$ & $\begin{array}{c}3.57 \\
1.54 \\
0\end{array}$ & $\begin{array}{c}0.4 \\
0.5 \\
2.00 \\
0\end{array}$ & $\begin{array}{l}1.33 \\
1.99 \\
2.70 \\
3.46\end{array}$ & $\begin{array}{l}9.15 \\
9.14\end{array}$ & $\begin{array}{l}10.87 \\
10.34\end{array}$ \\
\hline
\end{tabular}


Table 3. Fuel Composition and Property Results for Survey Gasolines in Study Countries

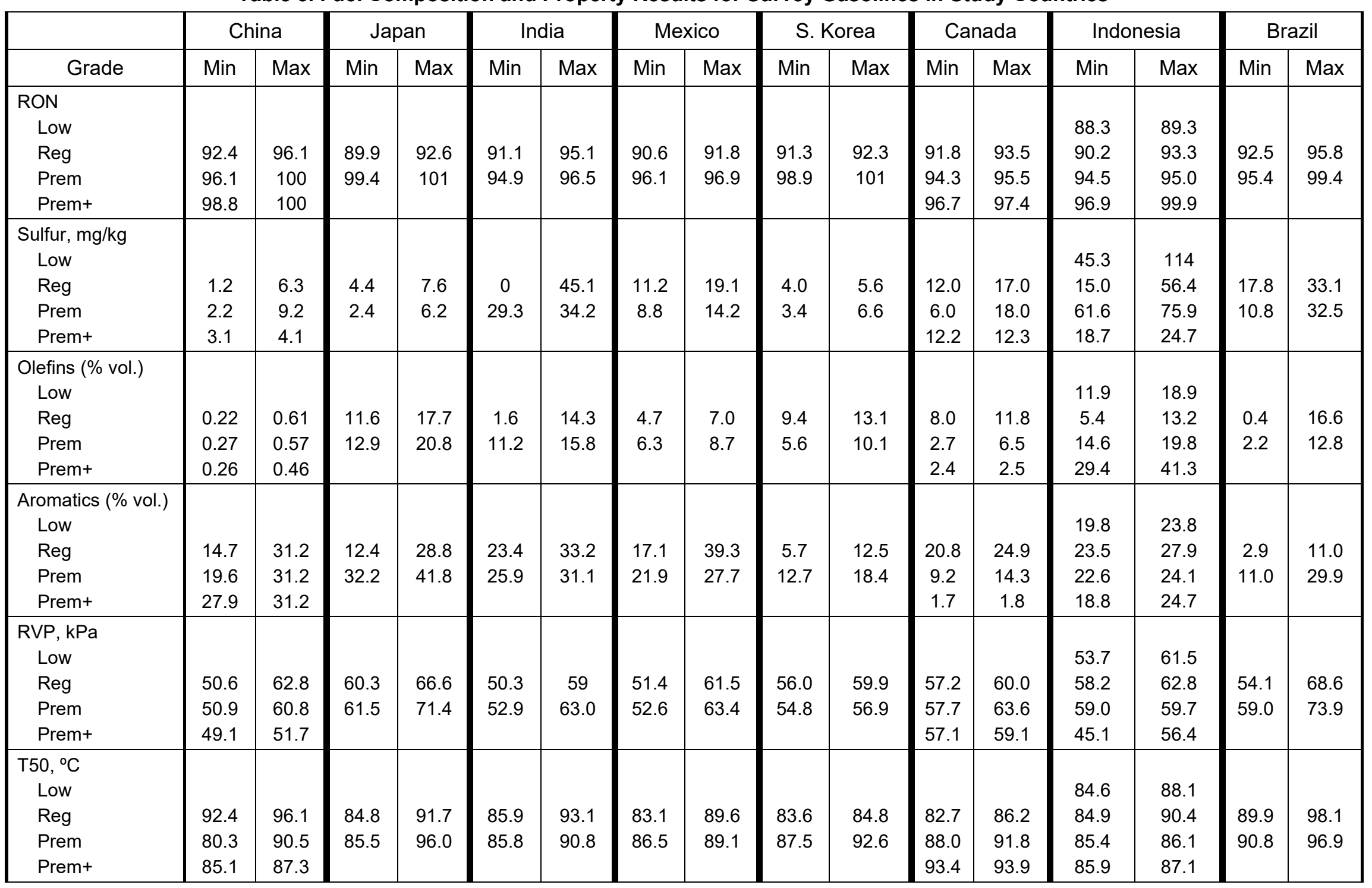




\subsection{Japan}

The Ministry of Economy, Trade, and Industry implements Japan's biofuel policy through its annual target volume of 500 million liters of crude oil equivalent (about 132 million gallons) in the transportation sector through fiscal year (April-March) 2022. ETBE is overwhelmingly used to fulfill the mandate, yet some ethanol is directly blended. More than $90 \%$ of ETBE consumed in Japan is supplied from a single U.S. Texas-based facility that converts Brazilian sugarcanebased ethanol and U.S. corn-based ethanol along with the petrochemical isobutylene into ETBE (Sasatani 2020). Japan recently increased its ethanol blend level (as ETBE) from a previous 1.6\% in 2019 to an expected $1.9 \%$ in 2020, despite an 8\% decrease in gasoline sales due to COVID-19. Production of fuel ethanol in Japan was only 48,000 gallons in 2019, according to the U.S. Energy Information Agency (EIA 2020). This production is likely from a single facility, the JA Zen-noh plant located in the rice-growing Niigata prefecture. The resulting ethanol is used to make an E3 blend sold at six affiliated JA Zen-noh gas stations. As of 2020, the plant operates on a limited three-month basis (Sasatani 2020).

The Japanese gasoline fuel standard is JIS K2202:2012. This standard allows ethanol up to 3\% vol. maximum. Japan fuel survey samples were for two grades of gasoline. Of the seven regular fuel samples surveyed, two showed low concentrations of ethanol ranging from $0 \%$ vol. to $2.47 \%$ vol. The five premium samples contained negligible amounts of ethanol. No MTBE use was observed; however, regular fuel samples contained up to $6.88 \%$ vol. ETBE and, in the premium samples, ETBE ranged from 3.11\% vol. to $6.44 \%$ vol. Japanese premium gasoline had the highest average aromatic content of the studied countries, but was otherwise unremarkable.

\subsection{India}

Current goals of the India National Biofuels Policy are to blend E10 nationwide by 2022, and to phase in E20 beginning in April 2023 with full implementation by April 2025 (Sarwal 2021). An Indian standard for anhydrous ethanol blendstock was published in 2004 (IS: 15464: 2004). An Indian standard for E20, IS 17021:2018 has been developed in anticipation of the E20 mandate. India's average ethanol blending level was 6.4\% in 2019, and they produced 634 million gallons. The government also approved an interest subsidy of \$626 million to support domestic ethanol production capabilities (Voegele 2021).

India fuel survey samples were for regular and premium grades. Of the 13 regular gasoline samples, one was E5 and four were E10. MTBE was also reported in the regular samples at up to $8.36 \%$ vol. Of three premium fuel samples, one contained $9.6 \%$ vol. ethanol. Based on the survey samples, Indian gasoline appeared similar to global gasolines. Note that the survey data are from 2019 and show sulfur up to $45 \mathrm{ppm}$; the sulfur limit was lowered to $10 \mathrm{ppm}$ in 2020 (Shao 2020). The largest petroleum refinery in the world is in India (Jamnagar Refinery of Reliance Industries processes 1.24 million barrels per day) and India is a net exporter of finished gasoline.

\subsection{Mexico}

Mexico allows ethanol blending but has banned the use of ethanol in its largest gasoline markets-Mexico City, Guadalajara, and Monterrey. Ethanol is allowed in the remaining parts of the country at up to $5.8 \%$ vol., with some exceptions as described below. Fourteen million gallons of fuel ethanol were produced in 2019, and 46 million gallons were consumed, for an 
average blending level of $0.4 \%$ (EIA 2020; USGC 2021c; Trotta 2020). The EIA also indicates that U.S. exports of fuel ethanol to Mexico were 31 million gallons in 2019 and jumped to 65 million gallons in 2020. U.S. exports of finished gasoline to Mexico have grown dramatically in recent years (Figure 23).

The regulation governing fuels in Mexico is NORMA Oficial Mexicana NOM-086SEMARNAT-SENER-SCFI-2005, Especificaciones de los combustibles fósiles para la protección Ambiental (Official Mexican Rule NOM-086-SEMARNAT-SENER-SCFI-2005 Fossil Fuel Specifications for Protection of the Environment). In 2006, NOM-086SEMARNAT-SENER-SCFI-2005 was modified to effectively allow imports of E10 into the Mexican northern border states (Secretaría del Medio Ambiente y Recursos Naturales or SEMARNAT, 2006). Of the large volumes of finished gasoline exported from the United States to Mexico over the past two decades, it is unknown what fraction contained ethanol; however, given the dominance of E10 blends in the U.S. market, it seems likely that most was E10. MTBE and ETBE can also be used in gasoline at up to $2.7 \%$ wt. oxygen (Transport Policy n.d.).

The Mexico gasoline fuel standard is NOM-016-CRE-2016. Survey samples for Mexico were regular and premium grades and did not contain ethanol. MTBE use was reported and accounts for $1.36 \%$ vol. to $11.86 \%$ vol. and $11.45 \%$ vol. to $13.58 \%$ vol., respectively, for the six regular and six premium fuel samples,. Otherwise, Mexican gasoline was similar to other gasolines in the rest of the world.

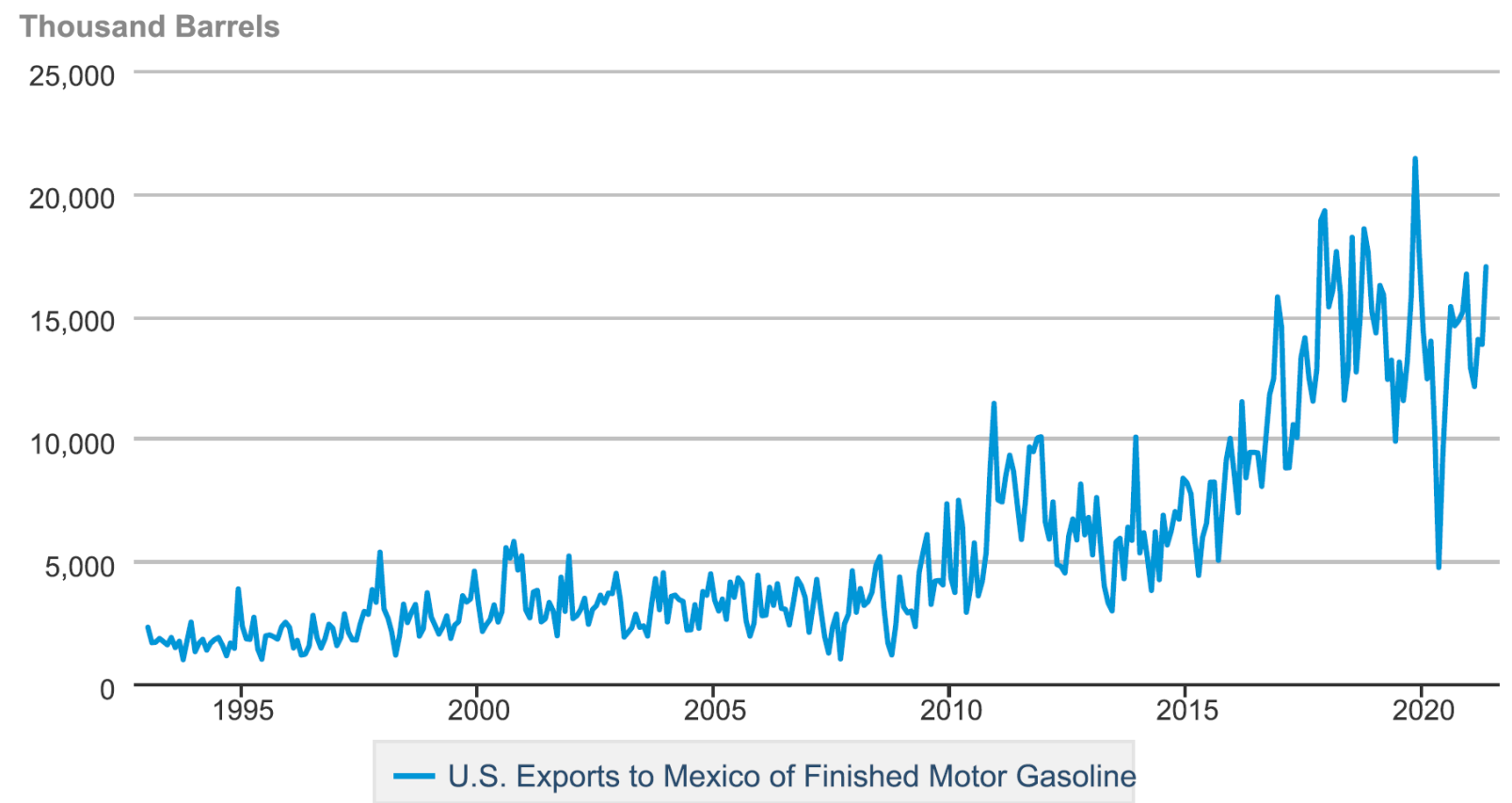

Figure 23. U.S. exports of finished gasoline to Mexico. Source: U.S. Energy Information Administration 


\subsection{South Korea}

Currently, ethanol is not blended into South Korean gasoline in any significant amount, and no fuel ethanol is produced in South Korea. The South Korean government is performing research into the viability of a national biofuels policy that could provide expanded ethanol market opportunities. A report published in June 2019 indicates that a feasibility study was conducted on ethanol blending in the transportation sector and is being reviewed by the Ministry of Trade, Industry, and Energy. The ministry is considering both ethanol blending and Japan's approach of using ETBE (FAS Seoul 2019).

South Korea fuel sample analysis reported no ethanol use in either of the five regular or three premium fuel samples. MTBE was reported at 5.48\% vol. $-11.05 \%$ vol. and $9.7 \%$ vol. $-10.4 \%$ vol. for the regular and premium fuel samples, respectively. Based on the properties in Table 3, South Korean gasoline is unremarkable. Three of the 10 largest oil refineries in the world are in South Korea with a combined processing capacity of 2.25 million barrels per day. This is more than 34 billion gallons of crude annually, and when compared to South Korea's annual gasoline consumption of 3.5 billion gallons, suggests that the country is a major exporter of refined petroleum products.

\subsection{Canada}

In Canada, federal regulations have required fuel producers and importers to have an average ethanol content of at least 5\% vol. This has been in effect since December 2010, and current usage averages 6.6\%. When combined, Ontario and Quebec account for 55\% of Canada's gasoline market. Their renewable fuel policies drive a large share of total Canadian demand for biofuels. Furthermore, from 2007 through 2020, several blend mandates went into effect in different provinces (Danielson 2020). Canada imports nearly half of the ethanol it uses, entirely from the United States.

The Canadian gasoline standard is CAN/CGSB-3.511-2016 for all regular unleaded gasoline and CAN/CGSB-3.5-2016 for premium unleaded gasoline. Canadian fuel survey samples included three grades - regular, premium, and premium plus. All six regular samples contained ethanol ranging from $9.35 \%$ vol. to $9.79 \%$ vol. The survey distinguished between premium and premium E10. The three premium samples contained no oxygenates; however, this is also true for two of the three premium E10 samples — a third contained 4\% vol. ethanol. Premium-plus samples also contained no oxygenates.

\subsection{Indonesia}

While Indonesia is a member of OPEC, it is a net importer of oil and finished gasoline. Indonesia currently has an ethanol mandate as part of the nation's biofuel targets published in December 2015. The required ethanol blend started at $2 \%$ in 2016, with planned increases to $10 \%$ in 2020 and $20 \%$ by 2025 (Rahmanulloh 2020; Transport Policy n.d.). Despite the mandate, no fuel ethanol is consumed in Indonesia. Indonesia imports approximately $50 \%$ of the finished gasoline it consumes (EIA 2020).

The Indonesian gasoline standard for RON 88 is SK Dirjen Migas 933.K/10_DJM.S/2013; for RON 90 gasoline, the standard is 313.K/10/DJM.T/2013; and for RON 91 and RON 95, the standard is $3674 \mathrm{~K} / 24 / \mathrm{DJM} / 2006$. Indonesian fuel survey samples are for four fuel grades-low 
regular (88 RON), regular, premium, and premium plus. No ethanol use was reported in any of the samples. Low regular showed MTBE ranging from 1.98\% vol.-3.22\% vol. Regular fuel samples showed MTBE ranging from 2.12\% vol.-5.96\% vol. Premium fuel samples showed MTBE ranging from $10.97 \%$ vol.- $14.25 \%$ vol. Premium-plus samples showed MTBE from $0.17 \%$ vol. $-5.48 \%$ vol.

\subsection{Brazil}

Brazil's current standards require a $27 \%$ blend of ethanol in gasoline (Transport Policy n.d.). Brazil's automotive applications have historically used two types of ethanol, including anhydrous ethanol and hydrous ethanol. Anhydrous ethanol is used for gasoline blends up to $27 \%$, at most containing $0.4 \%$ vol. water. Hydrous ethanol is primarily used as a substitute for gasoline in FFVs, as E100, or as a lower-level blend such as E85 (Martins et al. 2016). FFVs in the Brazilian market have been engineered to operate on any blend of hydrous ethanol, including up to E100.

The Brazilian gasoline standard is Resolution ANP No.40. Brazilian fuel survey samples were for regular and premium grades. Generally, fuel samples of both grades contained 25\% vol.-28\% vol. ethanol, clearly indicating that commonly used vehicles do not experience material or engine fuel-air ratio-control issues for these high-ethanol content blends.

\subsection{United States}

The United States currently uses up to $10 \%$ blend of ethanol in almost all gasoline; however, in 2011, the EPA granted a partial waiver under the Clean Air Act to allow the use of E15 in LDVs manufactured for the 2001 model year or later. In addition, FFVs can operate on ethanol blend levels up to $83 \%$ (EIA 2019).

\subsection{Potential Ethanol Market Size}

Table 4 shows the study countries' gasoline and fuel ethanol consumption for 2018 or 2019 (the most current year available). These data were then used to calculate the current average blend level. The table then shows the potential quantity of ethanol to be consumed if gasoline-fuel demands remain level and the countries achieve various blend levels. China is by far the largest consumer of gasoline of the study countries, followed at a distance by Japan. 
Table 4. Gasoline Consumption of the Study Countries and Potential Ethanol Consumption at Various Blend Levels (millions of gallons/year)- 2018 or 2019 Data

\begin{tabular}{|l|c|c|c|c|c|c|}
\hline Country & $\begin{array}{c}\mathbf{2 0 1 8} \text { or 2019 } \\
\text { Gasoline } \\
\text { Consumption }\end{array}$ & $\begin{array}{c}\mathbf{2 0 1 8} \text { or 2019 } \\
\text { Ethanol } \\
\text { Consumption }\end{array}$ & $\begin{array}{c}\text { Current } \\
\text { Average } \\
\text { Blend } \\
\text { Level } \\
(\%)\end{array}$ & $\begin{array}{c}\text { E10 Potential } \\
\text { Ethanol } \\
\text { Consumption }\end{array}$ & $\begin{array}{c}\text { E15 Potential } \\
\text { Ethanol } \\
\text { Consumption }\end{array}$ & $\begin{array}{c}\text { E20 Potential } \\
\text { Ethanol } \\
\text { Consumption }\end{array}$ \\
\hline China & 46,879 & 1,161 & 2.5 & 4,688 & 9,376 & 14,064 \\
\hline Japan & 13,055 & 209 & 1.6 & 1,306 & 2,611 & 3,917 \\
\hline India & 9,912 & 634 & 6.4 & 991 & 1,982 & 2,974 \\
\hline Mexico & 12,242 & 46 & 0.4 & 1,224 & 2,448 & 3,673 \\
\hline S. Korea & 3,555 & 0 & 0 & 356 & 711 & 1,067 \\
\hline Canada & 12,764 & 845 & 6.6 & 1,276 & 2,553 & 3,829 \\
\hline Indonesia & 9,106 & 0 & 0 & 911 & 1,821 & 2,732 \\
\hline
\end{tabular}

Source of gasoline and ethanol consumption: EIA 2020.

Note: Assumes 1 gallon of ethanol can replace 1 gallon of gasoline due to octane-related efficiency improvements (Johnson et al. 2015). Also assumes gasoline consumption remains stable with 2018 or 2019 (most recent year for EIA data) for illustration purposes. 


\section{Overall and Target Country Summaries}

Study questions:

1. Are vehicles in targeted countries physically and operationally compatible with ethanol blended fuel?

2. What ethanol blend levels are compatible with most of the existing fleet?

3. With such a large and diverse fleet of automobiles in use, are there vehicles that were not designed to use ethanol? Are there any vehicle engineering practices that make a certain type of vehicle prone to issues when operating on ethanol?

Based on the experiences of the United States and Brazil introducing E10 during the 1970s, it is highly likely that all LDVs globally are compatible with E10. While it is possible that many, or even all, of these LDVs are compatible with higher ethanol blend levels, there is a lack of in-use experience and data to support this claim. A large database acquired in the United States supports the statement that LDVs with the technology of U.S. Tier 1 emissions are highly likely to be compatible with E15. In some of the study countries, this includes nearly all of the LDVs on the road today. Published research on E20 strongly indicates that Tier 2 and newer LDVs are compatible with this fuel, but this conclusion is not as strongly supported as those for E10 and E15.

A similar analysis for motorcycles in India and Indonesia indicates full compatibility with E10 and that many motorcycles are also compatible with E15.

We did not identify any specific engine or vehicle designs, or engineering practices, that could cause issues when operating on ethanol.

Supporting information for these conclusions was derived from owners manual surveys, data on fuel imports, and data on the country's current oxygenate use.

\subsection{China}

China's automobile fleet is the newest of the countries studied, with only $2 \%$ of LDVs more than 15 years old. Key facts about the Chinese fuels and vehicle markets follow.

\section{Fuels Market}

- The gasoline market was more than 46 billion gallons in 2019 , and nearly 1.2 billion gallons of ethanol were blended, for an average blend rate of $2.5 \%$ (EIA 2020). This ethanol was primarily produced domestically, making China the fourth-largest ethanolproducing country in the world. National standards for denatured fuel ethanol (GB 18350 ) and E10 gasoline (GB 18351) have been adopted. Fuel survey samples showed the presence of $10 \%$ vol. ethanol as well as $10 \%$ vol. MTBE. Gasoline survey samples were all below $10 \mathrm{ppm}$ sulfur.

- At E10, the potential gasoline ethanol blending market is 4.7 billion gallons per year. The National Energy Administration announced a plan for nationwide use of E10 gasoline by 2020 and, in 2018, E10 was available in 12 provinces. Currently, because of COVID-19, insufficient ethanol production capacity, and a decline in national corn 
stocks, the nationwide E10 mandate was suspended but remains in place in 11 provinces. China has levied significant import tariffs on fuel ethanol — as high as 70\% in 2018 - but recently reduced those to $45 \%$ (USGC 2021a; Rueters, and Matthew Lewis. 2021).

\section{Light-Duty Vehicles}

- China has more than 220 million LDVs of which 214 million operate on gasoline. China imports roughly $5 \%$ of new LDVs sold with the balance produced in China. LDV manufacturing is highly diverse in China with more than 260 automakers included in the Experian database. The Chinese vehicle fleet is very new, with $98 \%$ registered since 2005.

\section{Ethanol Compatibility}

- The CN 2 standard, equivalent to Euro 2, was introduced in 2004. As Euro 2 is roughly equivalent to U.S. Tier 1, at least $98 \%$ of the LDVs in China should be compatible with blends up to E15. This is supported by the widespread use of E10 in China and the existence of a national standard for E10 fuels.

\subsection{Japan}

Japan's automobile fleet has employed closed-loop control, three-way catalysts since the early 1980s. Key facts about the Japanese fuels and vehicle markets follow.

\section{Fuels Market}

- The gasoline market was over 13 billion gallons in 2019 , with an average ethanol blend rate of 1.6\% (EIA 2020). The standard for motor gasoline, JIS K 2202:2012, allows ethanol at up to $3 \%$ vol. Fuel survey samples showed ethanol concentration up to $2.47 \%$. ETBE is blended at up to $6.8 \%$. Gasoline survey samples were all below $10 \mathrm{ppm}$ sulfur.

- At E10, the potential gasoline ethanol blending market is 1.3 billion gallons per year, but would require modification of the gasoline standard. Japan's biofuel policy has an annual target of about 132 million gallons that is currently met by blending of ETBE.

\section{Light-Duty Vehicles}

- Japan has 80 million gasoline LDVs that are almost entirely domestically produced-20\% are more than 15 years old, with more than $95 \%$ equipped with three-way catalyst, closedloop control emissions systems.

\section{Ethanol Compatibility}

- An emissions standard similar to U.S. Tier 0, requiring three-way catalysts, was adopted in the early 1980s. Tier 1 emissions were required beginning in 2000; Tier 2, beginning in 2005. Thus, essentially all LDVs in Japan should be compatible with E10. New LDVs registered since 2000 should be compatible with E15-although we do not know the breakdown of model years for 2005 and older LDVs.

- However, given that the gasoline standard only allows E3 blends, additional investigation may be required to understand ethanol compatibility in this market. 
- Toyota, which manufactured 28\% of Japan's LDVs, seems to approve of E10 for models that have a large foreign market share (such as the Corolla, Camry, Prius, and Vitz), but LDVs targeting the domestic market (such as the Pixis and Prius Alpha) are not approved to use ethanol. This is based on a very limited owners manual search for the models listed.

\subsection{India}

India has been rapidly modernizing its auto emissions and fuel regulations with the goal of reducing air pollution. Key facts about the Indian fuels and vehicles markets follow.

\section{Fuels Market}

- The gasoline market was 9.9 billion gallons in 2019, and 634 million gallons of domestically produced ethanol was blended - for an average blend rate of $6.4 \%$ (EIA 2020). The gasoline standard, IS 17021:2018 covers ethanol blending at 20\% vol. Fuel survey samples showed the presence of ethanol as well as MTBE, which is allowed at up to $15 \%$ vol. As of 2020, 10 ppm sulfur gasoline is available nationwide, although survey samples from 2019 included some with sulfur up to 45 ppm (ICCT 2020).

- At E10, the potential gasoline ethanol blending market is 990 million gallons per year. India's National Biofuel Policy has a goal of E10 by 2022 and E20 to be phased in from 2023 to 2025 .

\section{Light-Duty Vehicles}

- India has 25 million gasoline LDVs in operation (not including motorcycles and threewheelers). Sixty-six percent of new LDVs sold are manufactured in India and $43 \%$ are produced by a single vehicle maker, Maruti. Recent owners manuals of popular automobile models indicate E10 compatibility.

Two- and Three-Wheeled Vehicles

- More than 160 million two- and three-wheeled vehicles were registered in India since 2012, and the estimated total population is more than 180 million. Motorcycles and three-wheelers consume $60 \%$ of the gasoline used in India (Anup and Yang 2020). Bajaj, Hero, Honda, and TVS account for $89 \%$ of new two- and three-wheeled vehicles sold since 2012 .

\section{Ethanol Compatibility}

- Since 2005, new LDVs sold in India were required to meet the BS II standard, paralleling the Euro 2 emissions standard and roughly equivalent to U.S. Tier 1, such that these and newer vehicles should be compatible with E15. Pre-2005 vehicles make up $11 \%$ of the gasoline LDV fleet and should be compatible with E10.

- Indian motorcycles met the BS I (Euro 1) emissions standard beginning in 2000 and the BS II (Euro 2) in 2005. In other parts of the world, motorcycles meeting these or equivalent standards are considered compatible with E10. Owners manuals for the most recent model year indicate E10 compatibility for Honda models and some others. Hero indicates acceptance of fuels meeting the IS 2796:2017 E5 motor gasoline grade. While some models may be compatible with higher level ethanol blends, it is difficult to make an assessment based on available information. 


\subsection{Mexico}

Mexico has been modernizing its auto emissions and regionally adapting its fuel regulations with the goal of reducing air pollution. Key facts about the Mexican fuels and vehicle markets follow.

\section{Fuels Market}

- Mexico's gasoline market was 12.2 billion gallons in 2019 .

- While ethanol blending is allowed by Mexico's current fuel standard (NOM-016-CRE-2016), ethanol is banned in its largest gasoline markets: Mexico City, Guadalajara, and Monterrey. Ethanol is allowed in the remainder of Mexico at up to $5.8 \% \mathrm{vol}$; however, in the northern border states, regulations have allowed importation of finished gasoline from the United States, which is largely E10. In 2019, 46 million gallons of ethanol were used - not counting any imported E10. Six fuel survey samples each of regular and premium gasoline showed no ethanol present.

- Mexico allows MTBE and ETBE to be blended in gasoline at up to 2.7\% wt. oxygen. Six fuel survey samples showed between $1.36 \%$ vol. and $11.86 \%$ vol. MTBE in regular and between $11.45 \%$ vol. and $13.58 \%$ vol. MTBE in premium. No ETBE was found in fuel survey samples.

\section{Light-Duty Vehicles}

- Mexico has 33.3 million LDVs in operation (not including motorcycles and threewheelers), with 31.1 million of those operating on gasoline.

- From 1993-2004, Mexico used EPA Tier 0 emissions standards. After 2004, Mexico allowed manufacturers to comply with emissions limits based on EPA (Tier 1 and 2) or European (Euro 3 and 4) standards. Unlike the United States and Canada, Mexico has not transitioned to EPA Tier 3 standards.

- Mexico has the oldest vehicle fleet of the study countries, with $41 \%$ of gasoline-using LDVs manufactured before 2005 and a median age of 14 years. Nearly 15\% of LDVs are not equipped with three-way catalysts.

- Mexico's new LDV market is dominated by Nissan, GM (Chevrolet), VW, and Ford.

\section{Ethanol Compatibility}

- The 2004 and newer LDVs with Tier 1 emissions technology level should be compatible with blends up to E15, according to our analysis. Older LDVs should be compatible with E10.

\subsection{South Korea}

South Korea uses MTBE instead of ethanol as its gasoline oxygenate. Key facts about the South Korean fuels and vehicle markets follow.

\section{Fuel Market}

- South Korea's gasoline market was the smallest of the study countries (3.6 billion gallons in 2018) with very little ethanol blended.

- South Korea's Current Select Gasoline Standards require between 0.5\% wt. and 2.3\% wt. oxygen (Transport Policy 2021), which would allow for up to E6.3. However, they currently 
fulfill this oxygen requirement with MTBE. The Ministry of Trade, Industry, and Energy is considering both ethanol blending and ETBE (FAS Seoul 2019).

- At E10, the potential gasoline ethanol blending market is 356 million gallons per year.

Light-Duty Vehicles

- South Korea has 22.5 million gasoline LDVs in operation; 21\% were manufactured before 2005.

- Tier 1 emissions standards were introduced in 1994; Tier 2 standards, in 2001.

Ethanol Compatibility

- Given the high level of emissions-control technology for the entire fleet of LDVs in South Korea, these LDVs should be compatible with blends up to E15, according to our analysis.

\subsection{Canada}

Canada's auto emissions and fuel regulations have tracked with the United States since 1998. Key facts about the Canadian fuels and vehicle markets follow.

\section{Fuel Market}

- Canadian gasoline has an average of $6.6 \%$ ethanol, with goals to reach $15 \%$ by 3030 ; E10 use is common.

- A minimum of 5\% ethanol is required in Canadian gasoline.

Light-Duty Market

- Canada has 16.4 million gasoline LDVs currently in operation, with 19\% manufactured before 2005. Currently, $6.2 \%$ of the total LDV population adheres to the Tier 3 emissions standards.

- Tier 1 emissions standards were adopted in 1998, Tier 2 in 2009, and Tier 3 in 2017.

\section{Ethanol Compatibility}

- Canada's market is very similar to the United States in almost every regard. It has heavy overlap in manufacturers, manufacturing facilities, engines, and models. Therefore, given this and the overall high level of emissions-control technology of Canadian LDVs, it is likely that most of their LDVs are E15 compatible (new LDVs sold since 1998).

\subsection{Indonesia}

Indonesia has a national biofuels policy that mandates $5 \%$ ethanol blending in $2016,10 \%$ in 2020, and 20\% in 2025 for nongovernment vehicles (Rahmanulloh 2020); however, this mandate is not enforced. Key facts about the Indonesian fuels and vehicle markets follow.

Fuel Market

- The gasoline market was 9.1 billion gallons in 2019. Indonesia imports approximately $50 \%$ of the finished gasoline consumed (EIA 2020). 
- While the current policy mandates blending of $10 \%$ vol. ethanol in 2020 , ethanol is not currently being blended.

- At E10, the potential gasoline ethanol blending market is 911 million gallons per year.

Light-Duty Vehicles

- Indonesia has 14.1 million gasoline LDVs and the second-oldest vehicle fleet of the countries considered - with $32 \%$ of LDVs more than 15 years old.

- Emissions standards equivalent to Tier 1 were introduced in 2005, and standards equivalent to Tier 2 in 2018. A combined $68 \%$ of LDVs meet these requirements, with $6.8 \%$ meeting Tier 2 standards.

- A search of a limited number of owners manuals of Indonesia's most popular models also indicate E10 compatibility for recent model year LDVs.

Two- and Three-Wheeled Vehicles

- There are more than 100 million motorcycles and three-wheeled vehicles in Indonesia, with 59 million registered since 2012.

- Across model years 2012-2020, motorcycles account for 85\% of the entire country's vehicles, compared to $15 \%$ for automobiles.

- Five global manufacturers accounted for $99 \%$ of the total fleet population. Furthermore, Honda and Yamaha account for 94\% of Indonesia's total motorcycle fleet.

- Indonesian motorcycles were required to meet Euro 2 emissions limits between 2005 and 2007. Euro 3 emissions limits came into effect in 2015 (Transport Policy n.d.)

\section{Ethanol Compatibility}

- As we anticipate all LDVs globally to have a high probability of compatibility with E10, we also conclude that the vehicles in Indonesia are compatible with E10. The 2005 and newer vehicles with Tier 1 emissions technology level should be compatible with blends up to E15, according to our analysis.

- Indonesia implemented Euro 2 emissions requirements for motorcycles in 2005 and Euro 3 in 2015. In other parts of the world, motorcycles with this level of technology are compatible with E10. While some models may be compatible with higher level ethanol blends, it is difficult to make an assessment based on available information. 


\section{References}

Advanced Motor Fuels (AMF). 2019. "E10 Compatibility Issues.” Technology Collaboration Programme by IEA. https://www.ieaamf.org/content/fuel information/ethanol/e10/e10 compatibility/.

AFDC. 2021. https://afdc.energy.gov/data/10331. Accessed August 1, 2021.

ANFAVEA. 2021. Brazilian Automotive Industry Yearbook. https://anfavea.com.br/anuario2021/anuario.pdf.

Anup, Sunitha, and Zifei Yang. 2020. "New Two-Wheeler Vehicle Fleet in India for Fiscal Year 2017-18." International Council on Clean Transportation. https://theicct.org/sites/default/files/publications/India-2W-fuel\%20consumption-2017-18.pdf.

Aradhey, Amit. 2019. "Biofuels Annual: India." Public IN9069. USDA Foreign Agricultural Service.

https://apps.fas.usda.gov/newgainapi/api/report/downloadreportbyfilename?filename=Biofuels $\%$ 20Annual_New\%20Delhi_India 8-9-2019.pdf.

ASEANStats. 2018. "Total Number of Registered Motorcycles (in Thousand)." ASEANStatsDataPortal. https://data.aseanstats.org/indicator/ASE.TRP.ROD.B.011.

Astra Honda. 2021. "Indonesia's Honda BeAT POP Specifications." Astra Honda. https://www.astra-honda.com/product/beat.

Barros, Sergio. 2019. "Biofuels Annual: Brazil." https://apps.fas.usda.gov/newgainapi/api/report/downloadreportbyfilename?filename=Biofuels $\%$ 20Annual_Sao\%20Paulo\%20ATO_Brazil_8-9-2019.pdf.

Bawase, Moqtik, Amita Baikerikar, and M. R. Saraf. 2013. "Material Compatibility of Elastomers and Plastics in Ethanol-Blended (E10) Gasoline." SAE Technical Paper 2013-260077. doi:10.4271/2013-26-0077.

Bawase, M., Saraf, M. 2017. "Systematic Evaluation of 20\% Ethanol Gasoline Blend (E20) as a Potential Alternate Fuel," SAE Technical Paper 2017-26-0072. doi:10.4271/2017-26-0072.

Bechtold, Rich, John F. Thomas, Shean P. Huff, Jim P. Szybist, Tim J. Theiss, Brian H. West, Marc Goodman, and Tom A. Timbario. 2007. "Technical Issues Associated with the Use of Intermediate Ethanol Blends (>E10) in the U.S. Legacy Fleet: Assessment of Prior Studies.” TM ORNL/TM-2007/37. https://info.ornl.gov/sites/publications/files/Pub7767.pdf.

BioFuels Digest Admin. 2011. "EPA Approves E15 for Model Years 2001 and Later, for Cars, SUVs, and Light Pickup Trucks." Biofuels Digest. 2011. https://www.biofuelsdigest.com/bdigest/2011/01/24/epa-approves-e15-for-model-years-2001and-later-for-cars-suvs-and-light-pickup-trucks/. 
Biofuels International. 2020. "Canada's Clean Fuel Standard a Boost for Biofuels Industry." Biofuels International Magazine. December 22, 2020. https://biofuels-news.com/news/canadasclean-fuel-standard-a-boost-for-biofuels-industry/.

Bradford, Harvey. 2019. "Biofuels Annual: Canada." https://apps.fas.usda.gov/newgainapi/api/report/downloadreportbyfilename?filename=Biofuels\% 20Annual_Ottawa_Canada_8-9-2019.pdf

China Association of Automobile Manufacturers, 2021. http://www.caam.org.cn/chn/1/cate 148/con 5232916.html.

Chattopadhyay, Vivek. 2014. "Two-Stroke Vehicles Are the Worst Polluters." Down to Earth. May 2014. https://www.downtoearth.org.in/news/twostroke-vehicles-are-the-worst-polluters44402.

Colombini, Ken. 2020. "RFA Review: Automakers Approve E15 in Nearly All 2021 Vehicles, but FFV Offerings Continue to Slide.” Renewable Fuels Association (blog). December 1, 2020. https:/ethanolrfa.org/2020/12/rfa-review-automakers-approve-e15-in-nearly-all-2021-vehiclesbut-ffv-offerings-continue-to-slide/.

Continental Automotive. 2019. "Worldwide Emission Standards and Related Regulations." https://www.continental-automotive.com/getattachment/8f2dedad-b510-4672-a0053156f77d1f85/EMISSIONBOOKLET_2019.pdf.

Danielson, Erin. 2020. “Biofuel Annual: Canada.” Public CA2020-0070. USDA Foreign Agricultural Service.

https://apps.fas.usda.gov/newgainapi/api/Report/DownloadReportByFileName?fileName=Biofue 1s\%20Annual Ottawa_Canada 06-19-2020.

Delphi Technologies. 2020. "Worldwide Emissions Standards - Passenger Cars and Light Duty Vehicles." https://www.delphi.com/sites/default/files/2020-

04/DELPHI $\% 20$ booklet $\% 20$ emission $\% 20$ passenger $\% 20$ cars $\% 202020 \% 20$ online $\% 20$ complet.pd f.

Dickerson, M. 2005. "Brazil's ethanol effort helping lead to oil self-sufficiency." The Seattle Times. June 17, 2005.

DieselNet. 2020. "China: Fuels." DieselNet—Fuel Regulations.

https://dieselnet.com/standards/cn/fuel.php\#intro.

Donovan, Brian J. 2009. "Perspective: U.S. Needs to Transition to Hydrous Ethanol as the Primary Renewable Transportation Fuel.” Green Car Congress. August 30, 2009. https://www.greencarcongress.com/2009/08/donovan-hydrous-20090830.html.

Dorn, P., A. M. Mourao, S. Herbstman. 1986. "The Properties and Performance of Modern Automotive Fuels.” SAE Technical Paper No. 861178. doi:10.4271/861178. 
Duffield, J.A., and K. Collins. 2006. "Evolution of Renewable Energy Policy." Choices 21 (1) https://www.choicesmagazine.org/2006-1/biofuels/2006-1-02.htm.

Durbin, Thomas D., Georgios Karavalakis, Joseph M. Norbeck, Chan Sueng Park, Junior Castillo, Youngwoo Rheem, Kurt Bumiller, Jiacheng Yang, Vincent Van, and Kyle Hunter. 2016. "Material Compatibility Evaluation for Elastomers, Plastics, and Metals Exposed to Ethanol and Butanol Blends." Fuel 163 (January): 248-59.

https://doi.org/10.1016/j.fuel.2015.09.060.

Energy Information Administration (EIA). 2011. "Gasoline with Higher Ethanol Content Getting Closer to U.S. Drivers' Fuel Tanks-Today in Energy.” December 2011.

https://www.eia.gov/todayinenergy/detail.php?id=4230.

- 2019. "New EPA Ruling Expands Sale of 15\% Ethanol Blended Motor Gasoline."

Today in Energy. July 16, 2019. https://www.eia.gov/todayinenergy/detail.php?id=40095.

—. 2020. "International Overview" https://www.eia.gov/international/overview/world.

Environmental Protection Agency (EPA). 2010. "Partial waiver for E15 use in MY2007 and newer light-duty motor vehicles.” Federal Register Vol. 75, No. 213, 68094. November 4, 2010.

- 2011. "Partial waiver for E15 use in MY 2001-2006 light-duty motor vehicles." Federal Register Vol. 76, No. 17 4662. January 26, 2011.

FAS Seoul. 2019. "Biofuels Annual: Wrap-up Report for 2019 Seoul Fuel Ethanol Conference." https://kr.usembassy.gov/wp-content/uploads/sites/75/KS-1922 Wrap-Up-Report-for-2019-

Seoul-Fuel-Ethanol-Conference_2019-06-28.pdf.

Ford.ca. 2021. "Ford Warranty \& Towing Guides \& Owner Manuals."

https://www.ford.ca/owners/support/guides-and-manuals/.

Gibbs, L., and B. Gilbert. 1981. "Contra Costa County's One-Year Experience with Gasohol." SAE Technical Paper 810440. https://doi.org/10.4271/810440.

Growth Energy. 2021. "Supporting American Ethanol.” Growth Energy. https://growthenergy.org/about-us/.

Gu, Karl, and Hallie Plume. 2021. "China Bought about 200 Million Gallons of U.S. Ethanol for First-Half 2021: ADM.” Reuters. January 27, 2021. https://www.reuters.com/article/us-usachina-ethanol-idUSKBN29V282.

Hero MotoCorp. 2021. "Owner's Manuals-Hero MotoCorp Ltd.” https://www.heromotocorp.com/en-in/owners-manual.php. 
Heywood, John B. 2018. "Internal Combustion Engine Fundamentals, Second Edition." McGraw-Hill Education- Access Engineering. https://www.accessengineeringlibrary.com/content/book/9781260116106?implicit-login=true.

Hilbert, David. 2011. "High Ethanol Fuel Endurance: A Study of the Effects of Running Gasoline with 15\% Ethanol Concentration in Current Production Outboard Four-Stroke Engines and Conventional Two-Stroke Outboard Marine Engines." NREL/SR-5400-52909. National Renewable Energy Laboratory (NREL), Golden, CO (United States). https://doi.org/10.2172/1028047.

Honda. 2020a. "Honda Motorcycle Service Publications (Owner's Manual and Part Catalog)." https://www.hondamotopub.com/.

_.2020b. "India's Honda Activa 125 Scooter Specifications." https://www.honda2wheelersindia.com/activa125-BS-VI/specifications.

Hyundai Motor India. 2021. "Owner's Manual—All Hyundai Vehicle." https://www.hyundai.com/in/en/connect-to-service/hyundai-service/owners-manual.

ICCT. 2014. "Bharat Stage IV Emission Standards for Two-Wheelers in India." https://theicct.org/sites/default/files/publications/ICCTupdate_BSIV-motorcycles_aug2014.pdf

- 2020. "Policy Update: Brazil PROCONVE L-7 and L-8 Emission Standards for Lightduty Vehicles." International Council on Clean Transportation. https://theicct.org/sites/default/files/publications/Brazil L7L8 policy update 01302020.pdf.

_. 2016. "Technical Background on India BS VI Fuel Specifications." https://theicct.org/publications/technical-background-india-bs-vi-fuel-specifications

Iyer, N.V. 2012. "A Technical Assessment of Emissions and Fuel Consumption Reduction Potential from Two and Three Wheelers in India." https://theicct.org/sites/default/files/publications/Iyer_two-threewheelers_India_August2012.pdf.

Jandl, Stephan, Stephan Schmidt, Pascal Piecha, Hans-Juergen Schacht, and Tilman Seidel. 2018. "Influence of Ethanol and 2-Butanol Blended Fuels on Combustion and Emissions in a Small Displacement Two Stroke Engine." SAE Technical Paper 2018-32-0044. doi.org/10.4271/2018-32-0044.

Johnson, Caley, Emily Newes, Aaron Brooker, Robert McCormick, Steve Peterson, Paul Leiby, Rocio Uria Martinez, Gbadebo Oladosu, and Maxwell L. Brown. 2015. "High-Octane Mid-Level Ethanol Blend Market Assessment." National Renewable Energy Laboratory (NREL), Golden, CO, United States. NREL/TP-5400-63698. https://doi.org/10.2172/1351596.

Joseph, J., and D. Grogan. 1980. "Fleet Experience Using Three Blends of Ethanol and Unleaded Gasoline.” SAE Technical Paper 801361. doi.org/10.4271/801361. 
Joshi, Ameya. 2019. "Review of Vehicle Engine Efficiency and Emissions." SAE Technical Paper 2019-01-0314. doi.org/10.4271/2019-01-0314.

Kamakaté, Fatumata. 2009. "Managing Motorcycles: Opportunities to Reduce Pollution and Fuel Use from Two- and Three-Wheeled Vehicles." International Council on Clean Transportation. https://theicct.org/publications/managing-motorcycles-opportunities-reduce-pollution-and-fueluse-two-and-three-wheeled.

Kass, M., Theiss, T., Janke, C., Pawel, S., Lewis, S. 2011. "Intermediate Ethanol Blends Infrastructure Materials Compatibility Study: Elastomers, Metals, and Sealants" ORNL/TM2010/326.

Kass, M., Theiss, T., Pawel, S., Baustian, J. et al. 2014. "Compatibility Assessment of Elastomer Materials to Test Fuels Representing Gasoline Blends Containing Ethanol and Isobutanol, "SAE Int. J. Fuels Lubr. 7(2):2014, doi:10.4271/2014-01-1462.

Kim, Gene. 2019. "Biofuels Annual: China Will Miss E10 by 2020 Goal by Wide Margin." Public CH19047. USDA Foreign Agricultural Service. https://apps.fas.usda.gov/newgainapi/api/report/downloadreportbyfilename?filename=Biofuels $\%$ 20Annual_Beijing_China\%20-\%20Peoples\%20Republic\%20of_8-9-2019.pdf.

Kittleson, D., A. Tan, D. Zarling, B. Evans, and C. Jewitt. 2008. "Demonstration and Driveability Project to Determine the Feasibility of Using E20 as a Motor Fuel." http://www.mda.state.mn.us/renewable/ethanol/ /media/Files/renewable/ethanol/e20drivability.a $\underline{\operatorname{shx}}$.

Knoll, K., B. West, W. Clark, R. Graves, J. Orban, S. Przesmitzki, and T. Theiss. 2009. “Effects of Intermediate Ethanol Blends on Legacy Vehicles and Small Non-Road Engines, Report 1Updated.” ORNL/TM-2008-117; NREL/TP-540-43543. National Renewable Energy Laboratory (NREL), Golden, CO (United States). https://doi.org/10.2172/949053.

KnowIndia. 2017. “Indian Motor Vehicles.” Indian Auto Industry. March 2017. http://www.knowindia.net/auto.html.

Küüt, Keio, Risto Ilves, Arne Küüt, and Jüri Olt. 2020. "The Impact of the Bioethanol Fuel on the Exhaust Gas Emission of a Two-Stroke Engine.” In TRANSBALTICA XI: Transportation Science and Technology, edited by Kasthurirangan Gopalakrishnan, Olegas Prentkovskis, Irina Jackiva, and Raimundas Junevičius, 185-92. Lecture notes in Intelligent Transportation and Infrastructure. Cham: Springer International Publishing. https://doi.org/10.1007/978-ay03038666-5 19.

Loesche, Jon. 2017. "Impact of E20 Fuel on a High-Performance, Two-Stroke Engine." Dissertations, Master's Theses, and Master's Reports. https://doi.org/10.37099/mtu.dc.etdr/358. 
Martins, Fernanda Pinheiro, Pedro Teixeira Lacava, Claudia Regina de Andrade, and Sandra Garzuzi. 2016. "Alternative Fuels: A Review About Anhydrous and Hydrous Ethanol Properties.” SAE Technical Paper 2016-36-0409. doi.org/10.4271/2016-36-0409.

Maruti Suzuki India Limited. nd. "Maruti Suzuki Car Care.” Maruti Suzuki Service. nd. https://www.marutisuzuki.com/service/car-care.

McCormick, Robert L., Janet Yanowitz, Matthew Ratcliff, and Bradley T. Zigler. 2013. "Review and Evaluation of Studies on the Use of E15 in Light-Duty Vehicles."

https://www.ourenergypolicy.org/wpcontent/uploads/2013/12/b378858ac325c6e165 sgm6bknd4.pdf.

METI. 2021. 2020 Yearbook of Current Production Statistics-Machinery. https://www.meti.go.jp/statistics/tyo/seidou/result/gaiyo/resourceData/03 kikai/nenpo/h2dcd202 $\underline{0 \mathrm{k} . p d f}$.

Meyer, D., L. Mytelka, R. Press, E.L. Dall'Oglio, de Sousa Jr, P.T. \& A. Grubler. 2012. Brazilian Ethanol: Unpacking a Success Story of Energy Technology Innovation. Historical Case Studies of Energy Technology Innovation in: Chapter 24, The Global Energy Assessment. Grubler A., Aguayo, F., Gallagher, K.S., Hekkert, M., Jiang, K., Mytelka, L., Neij, L., Nemet, G. \& C. Wilson. Cambridge University Press: Cambridge, UK.

Miers, Scott A., and Jason R. Blough. 2013. "Evaluating the Impact of E15 on Snowmobile Engine Durability and Vehicle Driveability: September 22, 2010-August 15, 2013." National Renewable Energy Laboratory (NREL), Golden, CO, United States. NREL/SR-5400-60115. https://doi.org/10.2172/1351838.

Morris, D. 1992. “Ethanol Policy and Development: 1978-1992.” Institute for Local SelfReliance.

Özer, Salih. 2019. "The Effects of Alcohol Addition to Fuel on Piston Wear in a Two-Stroke Engine.” International Journal of Energy and Engineering Sciences 4 (2): 43-52.

Park, I. J., Y. H. Yoo, J. G. Kim, D. H. Kwak, and W. S. Ji. 2011. "Corrosion Characteristics of Aluminum Alloy in Bio-Ethanol Blended Gasoline Fuel: Part 2. The Effects of Dissolved Oxygen in the Fuel." Fuel 90 (2): 633-39. https://doi.org/10.1016/j.fuel.2010.09.049.

Rahmanulloh, Arif. 2020. "Biofuels Annual: Indonesia.” August 3, 2020. https://apps.fas.usda.gov/newgainapi/api/Report/DownloadReportByFileName?fileName=Biofue 1s\%20Annual Jakarta_Indonesia 06-22-2020.

RFA. 2019. "E15 Approval Status for Light-Duty Vehicles (Model Years 2012-2020)." Renewable Fuels Association. https://files.constantcontact.com/a8800d13601/56027461-ef2e440a-9acf-99cfad2dde06.pdf. 
- 2020. “Annual U.S. \& World Fuel Ethanol Production.” Renewable Fuels Association (blog). https://ethanolrfa.org/statistics/annual-ethanol-production/.

_. 2021. "Ethanol Markets and Statistics." Renewable Fuels Association (blog). https://ethanolrfa.org/statistics/.

Ricardo Inc. 2010. "Technical Assessment of the Feasibility of Introducing E15 Blended Fuel in U.S. Vehicle Fleet, 1994 to 2000 Model Years.” Renewable Fuels Association. RD.10/231405.1. https://www.farmanddairy.com/wp-content/uploads/2010/10/Ricardo-study-on-E15.pdf.

Rueters, and Matthew Lewis. 2021. "U.S. Ethanol Output Slips as China Rumored to Be Back in the Market." Hellenic Shipping News Worldwide. January 2, 2021.

https://www.hellenicshippingnews.com/u-s-ethanol-output-slips-as-china-rumored-to-be-backin-the-market/.

Sarwal, R., Kumar, S., Mehta, A., Varadan, A., Singh, K.S., Ramakumar, S.S.V., Mathai, R. 2021. "Roadmap for Ethanol Blending in India 2020-25" NITI Aayog. https://mopng.gov.in/files/uploads/Ethanol_blending_in_India_(7).pdf

Sasatani, Daisuke. 2020. “Biofuel Annual: Japan.” Public JA2020-0180. USDA Foreign Agricultural Service.

https://apps.fas.usda.gov/newgainapi/api/Report/DownloadReportByFileName?fileName=Biofue 1s\%20Annual_Tokyo_Japan_10-28-2020.

Schill, S. R. 2020. "Ethanol Producer Magazine-The Latest News and Data About Ethanol Production.” June 11, 2020. http://ethanolproducer.com/articles/17220/the-standoff-for-e30.

Seiter, R., and R. Clark. 1978. "Ford Three-Way Catalyst and Feedback Fuel Control System." SAE Technical Paper No. 780203. doi:10.4271/780203.

Secretaría del Medio Ambiente y Recursos Naturales (SEMARNAT), 2006. NOM-086SEMARNAT-SENER-SCFI-2005, pp. 19. http://www.profepa.gob.mx/innovaportal/file/1278/1/nom-086-semarnat-sener-scfi-2005.pdf

Shao, Zhenying. 2020. "Bharat Stage VI Emission Standards: Mission NOT Impossible.” International Council on Clean Transportation. April 2020. https://theicct.org/blog/staff/bharatstage-vi-mission-not-impossible.

Shoffner, B., R. JohnsonM. Heimrich, and M. Lochte. 2011. "Powertrain Component Inspection from Mid-Level Blends Vehicle Aging Study.” Report ORNL/TM-2011/65.

Society of Indian Automobile Manufacturers. 2021. https://www.siam.in/statistics.aspx?mpgid=8\&pgidtrail=13. 
Sluder, C. S., B. H. West, and K. Knoll. 2012. "Investigating Malfunction Indicator Light Illumination Due to Increased Oxygenate Use in Gasoline." SAE Technical Paper No. 2012-012305. doi:10.4271/2012-01-2305

Somwanshi, Rohan, Shikha Singh, and Mugunthan Kesavan. 2020. "Interview: China to Keep Ethanol Program Steady, National Blend Rate Seen at 4\%--U.S. Grains Council." S\&P Global Platts. September 30, 2020. https://www.spglobal.com/platts/en/market-insights/latestnews/agriculture/093020-interview-china-to-keep-ethanol-program-steady-national-blend-rateseen-at-4-us-grains-council.

Statista. 2020. "Indonesia: Number of Motorcycles 2019." July 2020. https://www.statista.com/statistics/978944/indonesia-number-of-motorcycles-use/.

_. 2021a. https://www.statista.com/statistics/650919/south-korea-vehicle-production-bytype/.

2021b. https://www.statista.com/statistics/600949/indonesia-passenger-car-production/.

The Royal Society. 2008. "Sustainable Biofuels: Prospects and Challenges." Policy document 01/08, January 2008.

https://royalsociety.org/ /media/royal_society_content/policy/publications/2008/7980.pdf

Toyota. 2016. "Toyota Yaris Owner's Manual Mexico.” https://www.toyota.com/t3Portal/document/om-s/OM52894S/pdf/OM52894S.pdf.

Toyota Astra Co. 2020. “Toyota Astra Motor.” https://www.toyota.astra.co.id/home.

Toyota Motor Corp. 2021. “Toyota Japan Owner's Manual.” http://toyota.jp/index.html.

Toyota MX. 2021. “Toyota Mexico Owner's Manual.” https://www.toyota.mx/propietarios-vin.

Transport Policy. 2021. "South Korea: Fuels: Diesel and Gasoline." https://www.transportpolicy.net/standard/south-korea-fuels-diesel-and-gasoline/.

. n. d. YEAR. "Indonesia: Fuels: Diesel and Gasoline."

https://www.transportpolicy.net/standard/indonesia-fuels-diesel-and-gasoline/.

n.d. "Mexico: Fuels: Diesel and Gasoline."

https://www.transportpolicy.net/standard/mexico-fuels-diesel-and-gasoline/.

.n.d. "Indonesia Motorcycle Emissions"

https://www.transportpolicy.net/standard/indonesia-motorcycles-emissions/

Trotta, Austin. 2020. "Mexico Supreme Court Ruling Opposes Fuel Ethanol." Stratas Advisors. March 10, 2020. https://stratasadvisors.com/Insights/2020/03102020-Mexico-Fuel-Ethanol. 
TVS Motor Company. 2021a. "TVS XL-Super Moped Owner's Manual." https://www.tvsmotor.com/customers/User-Manual.

—. 2021b. "TVS XL-Super Moped Specifications." https://www.tvsmotor.com/tvs-xl100.

United Nations Statistics Division. 2021. "Motor Gasoline.” January 2021.

http://data.un.org/Data.aspx?d=EDATA\&f=cmID\%3AMO.

U.S. Grains Council (USGC). 2021a. “China: Ethanol Market.” https://grains.org/buyingselling/ethanol-2/ethanol-market-profiles/china/.

—. 2021b. "Indonesia: Ethanol Market Overview." https://grains.org/buyingselling/ethanol-2/ethanol-market-profiles/indonesia/.

—. 2021c. "Mexico: Ethanol Market Overview." https://grains.org/buying-selling/ethanol2/ethanol-market-profiles/mexico/.

U.S. International Trade Administration. 2020. "Mexico - Country Commercial Guide" https://www.trade.gov/knowledge-product/mexico-e-automotive-parts-and-supplies.

U.S. Trade Representative. 2021. "2021 National Trade Estimate Report on Foreign Trade Barriers." https://ustr.gov/sites/default/files/files/reports/2021/2021NTE.pdf.

Veja, R. 1989. "Um sonho corroído" (in Portuguese). Editora Abril. May 24, 1989. Cited in: https://en.wikipedia.org/wiki/History of ethanol fuel in Brazil.

Voegele, Erin. 2020. "Report: Japan's Ethanol Blend Rate Expected at 1.9\% in 2020." Ethanol Producer Magazine. November 25, 2020. http://ethanolproducer.com/articles/17767/reportjapanundefineds-ethanol-blend-rate-expected-at-1-9-in-2020.

- 2021. "India Takes Action to Increase Use, Production of Ethanol." Ethanol Producer Magazine. January 19, 2021. http://www.ethanolproducer.com/articles/17898/india-takes-actionto-increase-use-production-of-ethanol.

Vyas, Dharmdev, Moqtik A. Bawase, and M. R. Saraf. 2013. "Study of Compatibility of Metals Used in Fuel System of Gasoline Engine with E10 and E20." https://doi.org/2013-01-2880.

West, B. H., C. S. Sluder, K. E. Knoll, J. E. Orban, and J. Feng. 2012. "Intermediate Ethanol Blends Catalyst Durability Program.” Report ORNL/TM-2011/234.

Yamaha. 2017. "Yamaha Fino 125 Scooter Owner's Manual.” July 2017. https://www.yamahamotor.co.th/docs/default-document-library/bb9-f8199-e1-fino-125-flex-fuelen.pdf?Status=Master\&sfvrsn $=722 \mathrm{~b} 817 \mathrm{~b} \_$. 
Yamaha Motor Co., Ltd. 2015. "Yamaha Motor to Launch New Fino 125 in Thailand, Model Featuring Blue Core Engine.” August 31, 2015. https://global.yamahamotor.com/news/2015/0831/fino125.html.

Yanowitz, J., M. Ratcliff, B. T. Zigler, and R. L. McCormick. 2013. Appendix: Studies on the Use of E15 and E20 in Light-Duty Vehicles. https://ethanolrfa.org/wp-

content/uploads/2015/09/RFA-NREL-Review-and-Evaluation-E15-Appendix.pdf.

Yao, Li-hong, Yan Gao, Wen-bin Li, and Jiang Wu. 2010. "Effects of the Mixture Fuel of Ethanol and Gasoline on Two-Stroke Engine." In proceedings of the 2010 International Conference on Intelligent Computation Technology and Automation-Volume 02, 188-91. ICICTA '10. USA: IEEE Computer Society. https://doi.org/10.1109/ICICTA.2010.29. 


\section{Appendix A. Materials Compatibility with Ethanol Blends}

Three main groups of materials, listed below, can be affected by ethanol exposure, or ethanol overexposure, and are considered during the study of this report.

Elastomers

- Properties can change with ethanol exposure

- Mass, volume, hardness, tensile strength, elongation

- Affects seal swelling/shrinkage, sealing, permeation, and low temperature performance.

Plastics

- Properties can change with ethanol exposure

- Mass, volume, tensile strength, elongation, impact strength

- Affects component dimensional stability, sealing, strength, permeation, and durability.

Metals

- Various levels of corrosion potential with ethanol blends

- Water + ethanol risk

- Electronics - corrosion potential to fuel pumps and level sensors.

Table A-1 contains a list of the most common materials used in fuel-system components. It also indicates the compatibilities with gasoline not containing ethanol (E0) and a comparison between E10 and E15 blends. However, it should be noted that this study only targeted vehicle model years from 1994-2000. At the time of publication, it can be seen that most materials identified in this study are relatively compatible with gasoline containing up to $15 \%$ vol. ethanol.

Additionally, it was noted that the study focused on on-road LDVs and concluded that the adoption and use of E15 would not adversely affect fuel-system components in the model years studied (Ricardo 2010).

A comprehensive exercise for evaluation of E20 fuel for change in material properties was conducted on four-wheelers and two-wheelers. The laboratory immersion study and results on typical plastics used in fuel-system components can be seen in Table A-2 and for elastomers in Table A-3.

Several online sources have credible information regarding ethanol-tolerant materials suitable for o-rings and gaskets. For example, www.efunda.com, a fundamental engineering website dedicated to providing concise and reliable engineering information, provides a table of materials compatible with ethanol and the severity of exposure indicated by a number and color rating system as seen in Table A-4. Similarly, a more extensive material o-ring handbook designed for material compatibility guidance can be found through $w w w$.parker.com. The handbook contains extensive information about the properties of basic sealing elastomers as well as examples of typical o-ring applications, fundamentals of static and dynamic seal design, and o-ring failure modes. An example of the Parker system can be seen in Table A-5, including the compound compatibility rating when exposed. 
Table A-1. Common Fuel System Materials-Locations and Compatibility

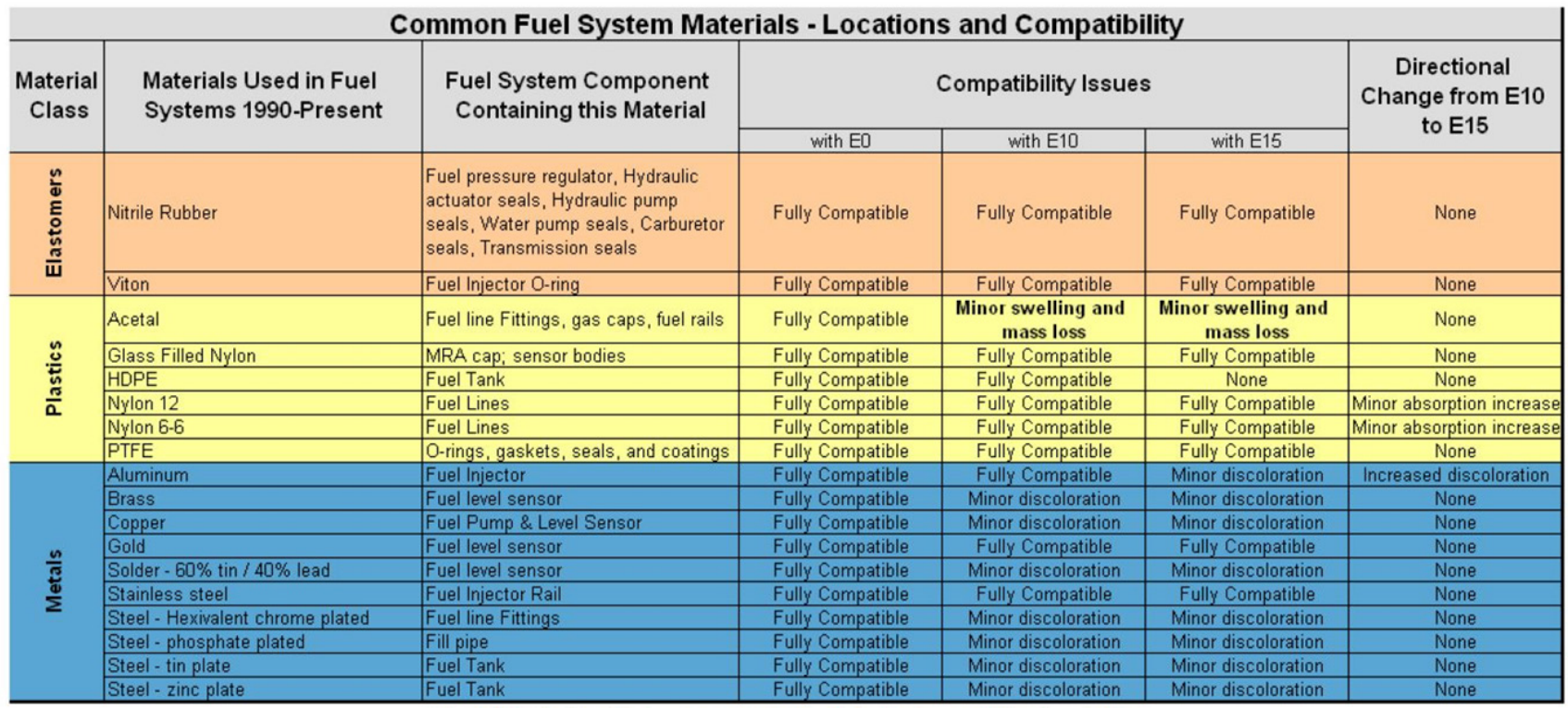

Source: Ricardo, 2010 study for RFA.

Table A-2. Plastics Materials Property Changes when Exposed to E20

\begin{tabular}{|c|c|c|c|c|c|}
\hline $\begin{array}{l}\text { Change } \\
\text { in } \\
\text { Property }\end{array}$ & Remarks & PA-66 & $\begin{array}{l}\text { Acetal } \\
\text { polymer }\end{array}$ & PBT & PA-12 \\
\hline $\begin{array}{c}\text { Weight } \\
(\%)\end{array}$ & $\begin{array}{l}\text { +ve implies increase in } \\
\text { weight is more in } \\
\text { gasoline. }\end{array}$ & -5 & -1 & -2 & -2 \\
\hline $\begin{array}{c}\text { Volume } \\
(\%)\end{array}$ & $\begin{array}{l}\text { +ve implies increase in } \\
\text { volume is more in } \\
\text { gasoline }\end{array}$ & -7 & -2 & -3 & -2 \\
\hline $\begin{array}{c}\text { Tensile } \\
\text { strength } \\
(\%)\end{array}$ & $\begin{array}{l}\text { +ve implies drop in } \\
\text { tensile is more in E20 }\end{array}$ & 21 & 0 & 8 & 1 \\
\hline $\begin{array}{c}\% \text { Elongati } \\
\text { on }(\%)\end{array}$ & $\begin{array}{c}\text { +ve implies increase in \% } \\
\text { elongation is more in } \\
\text { Gasoline }\end{array}$ & -25 & -1 & -4 & 1 \\
\hline $\begin{array}{l}\text { Impact } \\
\text { Strength }\end{array}$ & $\begin{array}{l}\text { +ve implies increase in } \\
\text { Impact strength is more } \\
\text { in Gasoline }\end{array}$ & -81 & -4 & 0 & -13 \\
\hline O & \multicolumn{4}{|l|}{ Better performance in E20 } & \\
\hline 0 & \multicolumn{4}{|c|}{ Similar Performance in both the fuels } & \\
\hline O & \multicolumn{4}{|c|}{ Better performance in Gasoline } & \\
\hline & \multicolumn{4}{|c|}{ Satistically significant with $95 \%$ confidence } & \\
\hline
\end{tabular}

Source: SAE Technical Paper 2017-26-0072. 
Table A-3. Elastomers Materials Property Changes when Exposed to E20

\begin{tabular}{|c|c|c|c|c|c|c|c|}
\hline $\begin{array}{l}\text { Change in } \\
\text { Property }\end{array}$ & Remarks & SBR & HNBR & $\begin{array}{c}\text { Fluoro } \\
\text { elastomer }\end{array}$ & \begin{tabular}{|c|} 
Polychlor \\
oprene
\end{tabular} & $\begin{array}{l}\text { NBR/ } \\
\text { PVC } \\
\end{array}$ & $\begin{array}{c}\text { Epichloro } \\
\text { hydrin }\end{array}$ \\
\hline Weight(\%) & $\begin{array}{l}\text { +ve implies increase in } \\
\text { weight is more in } \\
\text { gasoline. }\end{array}$ & 11.9 & 7.4 & -0.8 & 26.6 & -4.5 & -5.9 \\
\hline Volume(\%) & $\begin{array}{l}\text { +ve implies increase in } \\
\text { volume is more in } \\
\text { gasoline }\end{array}$ & 24.0 & 15.5 & -2.8 & 52.0 & -7.6 & -11.2 \\
\hline Hardness & $\begin{array}{l}\text { tve implies drop in } \\
\text { hardness is more in }\end{array}$ & -4.9 & -15.9 & 1.0 & -11.8 & 3.1 & -10.1 \\
\hline $\begin{array}{c}\text { Tensile } \\
\text { strength(\%) }\end{array}$ & $\begin{array}{l}\text { +ve implies drop in } \\
\text { tensile is more in E20 }\end{array}$ & -5.7 & -0.7 & 6.6 & -3.1 & 10.4 & 4.1 \\
\hline $\begin{array}{c}\text { \%Elongation( } \\
\%)\end{array}$ & $\begin{array}{c}\text { +ve implies drop in \% } \\
\text { elongation is more in } \\
\text { E20 }\end{array}$ & -8.6 & -1.7 & 5.7 & -6.4 & 18.3 & 12.0 \\
\hline
\end{tabular}

Source: SAE Technical Paper 2017-26-0072.

Table A-4. O-Ring Materials Compatible with Ethanol

\begin{tabular}{l|l|l|} 
& $\begin{array}{l}\text { O-Ring Materials Compatible with Ethanol } \\
\text { (select a material to show its compatible chemicals) }\end{array}$ & Butyl (4) \\
\hline Aflas (0) & Buna-N (Nitrile) (4) & Ethylene-Propylene (4) \\
\hline Chemraz (4) & Epichlorohydrin (4) & Hypalon (4) \\
\hline Fluorocarbon (4) & Fluorosilicone (4) & Neoprene (4) \\
\hline Kalrez (4) & Natural Rubber (4) & Polysulfide (4) \\
\hline Nitrile, Hydrogenated (4) & Polyacrylate (1) & Silicone (3) \\
\hline Polyurethane, Cast (0) & Polyurethane, Millable (1) & Vamac (0) \\
\hline Styrene Butadiene (4) & Teflon, Virgin (4) &
\end{tabular}

Source: Efunda.com 
Table A-5. Compound Compatibility Rating System

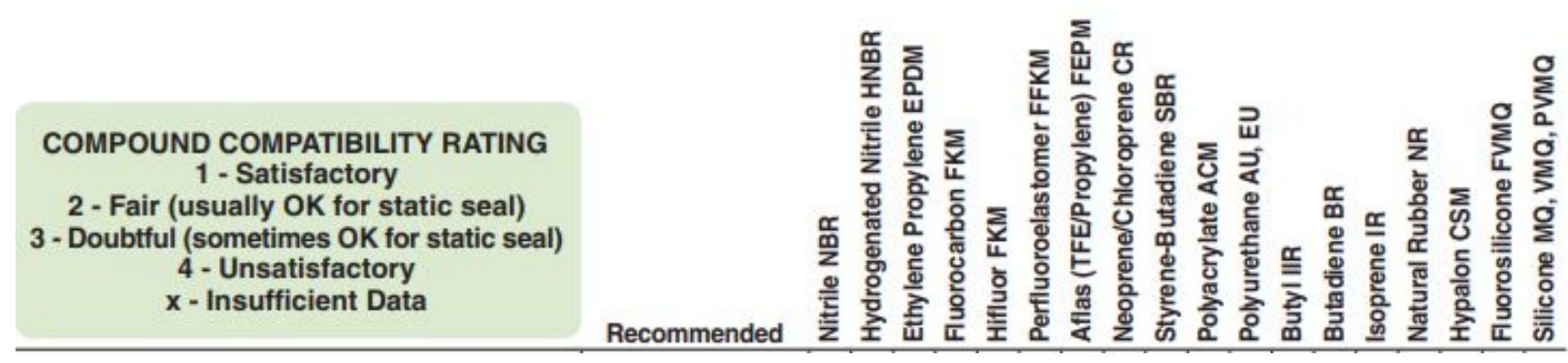

\begin{tabular}{|c|c|c|c|c|c|c|c|c|c|c|c|c|c|c|c|c|c|c|c|}
\hline Ethane & N0674-70 & 1 & 1 & 4 & 1 & 1 & 1 & $\mathrm{x}$ & 2 & 4 & 1 & 3 & 4 & 4 & 4 & 4 & \begin{tabular}{|l|l|l|l|l}
2 \\
\end{tabular} & 3 & 4 \\
\hline Ethanol & E0540-80 & 3 & 3 & 1 & 3 & 1 & 1 & $\mathrm{x}$ & 1 & 1 & 4 & 4 & 1 & 1 & 1 & 1 & \begin{tabular}{|l|}
1 \\
\end{tabular} & 1 & 2 \\
\hline Ethanol Amine & E0540-80 & 2 & 2 & 1 & 4 & 1 & 1 & $\mathrm{x}$ & 2 & 2 & 4 & 3 & 2 & 2 & 2 & 2 & 3 & 4 & 2 \\
\hline Ethers & V3819-75 & 4 & 4 & 3 & 3 & 1 & 1 & $\mathrm{x}$ & 4 & 4 & 3 & 2 & 4 & 4 & 4 & 4 & 4 & 3 & 4 \\
\hline Ethoxyethyl Acetate (EGMEEA) & E0540-80 & 3 & $\mid 3$ & 1 & 3 & 2 & 1 & $\mathrm{x}$ & 1 & 1 & 4 & 4 & 1 & 1 & 1 & & & & 2 \\
\hline
\end{tabular}

N1500-7

\begin{tabular}{|l|l|l|l|l|l|l|l|l|l|l|l|l|l|l|l|l|l}
\hline 1 & 1 & 4 & 1 & 1 & 1 & $\mathrm{x}$ & 4 & 4 & 4 & 2 & 4 & 4 & 4 & 4 & 4 & 1 & 4 \\
\hline
\end{tabular}

Source: Parker O-Ring Handbook. 


\section{Appendix B. GasPlus Waiver Request for EPA Approval of E10 Blends}


June 19, 1978

Director, Mobile Source

Enforcement Division

U.S. Environmental Protection Agency

401 M Street, S. W.

Washington, D. C. 20460

Application:

Waiver of 211(f) Clean Air Act Amendments of 1977

Applicants:

1. Jarnes Lustgarten, President

"Gas Plus", Inc.

3000 Street

Lincoln, Nebraska 68508

2. Al Mavis, Director

Farm Energy Conservation Program

Illinois Dept. of Agriculture

Springfield, Illinois 62790

Reason:

1) The above-named manufacturers of Gasohol, a blend of $90 \%$ unleaded regular gasoline and $10 \%$ annhydrous ethano1, request a waiver of $211(\mathrm{f})$ Clean Air Act Amendments to permit Gaşohol's distribution and sale.

2) 211 (f) (4) provides: "The Administrator, upon application of any manufacturers of any fuel or fuel additive, may-waive the prohibitions established under paragraph (1) or (3) of the subsection if he determines that the applicant has established that such fuel or fuel additive or a specified concentration thereof, and the emission products of such fuel or additive or specified concentration thereof will not cause or contribute to a failure of any emission control device or system (over the useful life of any vehicle in which such device or system is used) to achieve compliance by the vehicle with the emission standard with respect to which it has been certified pursuant to section 206."

3) Gasohol deserves such a waiver due to the fact it has nexer been shown to cause or contribute to the failure of any-emission control deviceor system installed on vehicles or engines to achieve compliance with applicable emission standards.

4) The above named manufacturers 1ack the tremendous resources necessary for the type of testing EPA 211(f) guidelines require. 
5) Therefore, until such time as the Environmental Protection Agency completes its own testing of Gasohol, we wish to submit thorough testing performed on the emission effects of 10 percent methanol and unleaded regular gasoline, as well as testing performed by Atlantic Richfield with mixtures of tertiary butyl alcohol and gasoline. Both of these alcohols are substantially sinilar to ethanol where emission control is concerned.

6) Research on ethanol blends has been but a fraction of the effort devoted to methanol blends. We are submitting what is presently available, but until such time as more extensive research is completed, we request and are prepared to accept a temporary waiver of 211 (f).

Supporting Documents: cation:

The following is a 1ist of documents we submit to support this app1i-

a. Ethanol blends :

1. Alcoho1: The Renewable Fuel from Our Nation's Resources. Republican Conference, U. S. Senate, October 1977, pp. 12-36.

2. Metharol and Ethanol Fuels - Ervironmental Health and Safety. Issues. Graham Hagey, et a1. pp. 16-20

3. Three-Way Conversion Catalysts on Vehicles Fueled with Ethano1 Gasoline Mixtures. J, J. Mooney, Sao Paulo, Brazil, January 1978.

b. Methanol blends -

1. On the Trail of New Fuels. Alternative Fuels for Motor Vehicles, West German Ministry for Research and Technology, 1974.

2. A1ternate Air-Fue1 Induction Systen Contrasts in Termis of Fue1 Economy and Exhaust Imissions for Sirnulated Driving CycIes with Methanol and Indolene. M. D. McCormack and R. K. Pefley, University of Santa Clara, Santa Clara, California 95053.

3. Utilization of Methanol as an Automotive Fue1 - A Report II EC-2, The Inter -Industry Emission Control Program. R. E. Baker, J. A. Harrington, et al.

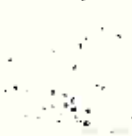


$-3-$

4. Predicted Methano1-Water Fueled ST Engine Performance and Emissions. Louis H. Browning and Richard K. Pefley, University of Santa Clara, Santa Clara, Ca1ifornia 95053

c. Tertiary Butyl Alcohol blends -

1. Technical Data. Atlantic Richfield Company.

This application is being submitted with the assistance of the U. S. Senate Republican Conference. Further requests or notifications should also be forwarded to Thomas Graves, Professional Staff, U.S. Senate Republican Conference, Room 333, Russe11 Building, Washington, D.C. 20510 (224-3496). 


\section{Appendix C. Additional Analyses of Vehicle Fleet Data}

\section{Vehicle Manufacturer Country of Origin for the Study Countries}

Figure C-1 shows the headquarters location of vehicle manufacturers in the various countries. It also shows the origin of the Brazilians and United States fleet for comparison purposes. The most notable feature of this chart is that China, Japan, and South Korea predominantly use vehicles produced by their own vehicle makers. India also has a very high percentage of vehicles produced by domestic companies.

Countries where a vast majority of the vehicles are domestically produced are probably less likely to be influenced (in terms of ethanol compatibility) by the ethanol content of gasoline in foreign countries than countries with many imported vehicles. In other words, these countries are more capable of matching their vehicles to their ethanol-related goals or lack thereof. This is most relevant in Japan, where $95 \%$ of the vehicles are produced domestically, China (94\% domestic), South Korea (87\%), and India (66\%).

The main exception to the assumption of countries with large domestic fleets being less influenced by foreign ethanol blend levels is when a country has major export markets. In this case, it is possible that manufacturers could build ethanol-compatible vehicles for all their markets to retain uniformity in materials and components. Therefore, the countries that export the most vehicles to ethanol-using countries would be the most likely to produce ethanolcompatible vehicles.

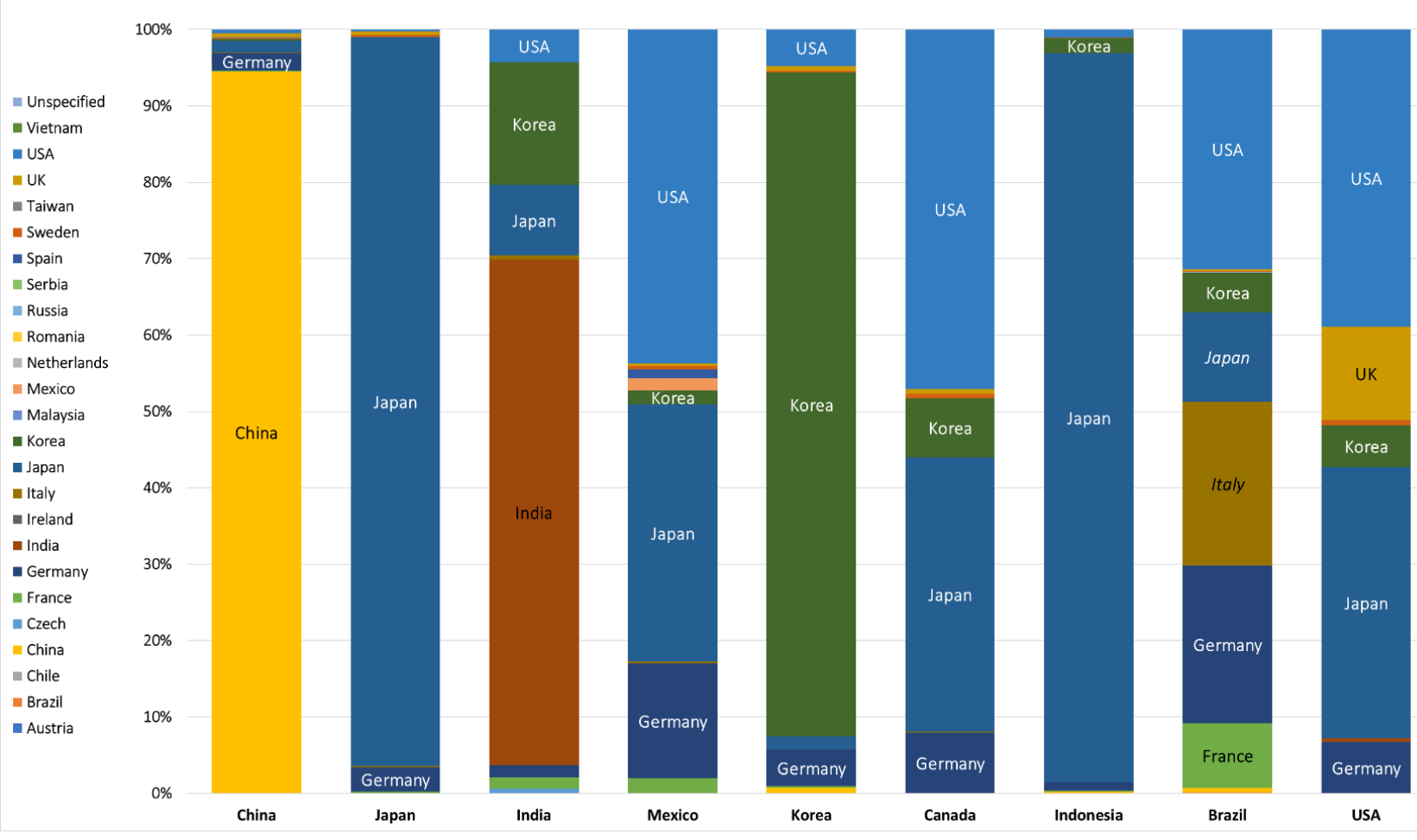

Figure C-1. Percent of vehicles in studied and comparison countries by country of origin Data Source: Experian VIO database, Q4 2019 
Vehicles have numerous components, materials, and other attributes that are common within a given manufacturer. Furthermore, the decisions to manufacture vehicles to be tolerant of a given level of ethanol are often made by the manufacturer (Colombini 2020). Therefore, two attributes of a country's vehicle fleet could indicate that introducing a given blend of ethanol in that country would be easier than others. The first is if the country's fleet was manufactured by a few dominant companies rather than by an extremely decentralized, diverse set of companies. The second is if the country's fleet was manufactured largely by companies that manufacture ethanolcompatible vehicles in countries where the targeted blend level is common. The complete charts of vehicle make by country are shown in the following figures. It should be noted that Experian tracks manufacturing entities at the make level to maintain consistency through mergers and acquisitions. It also lists different entities for manufacturing partnerships with Chinese manufacturers.

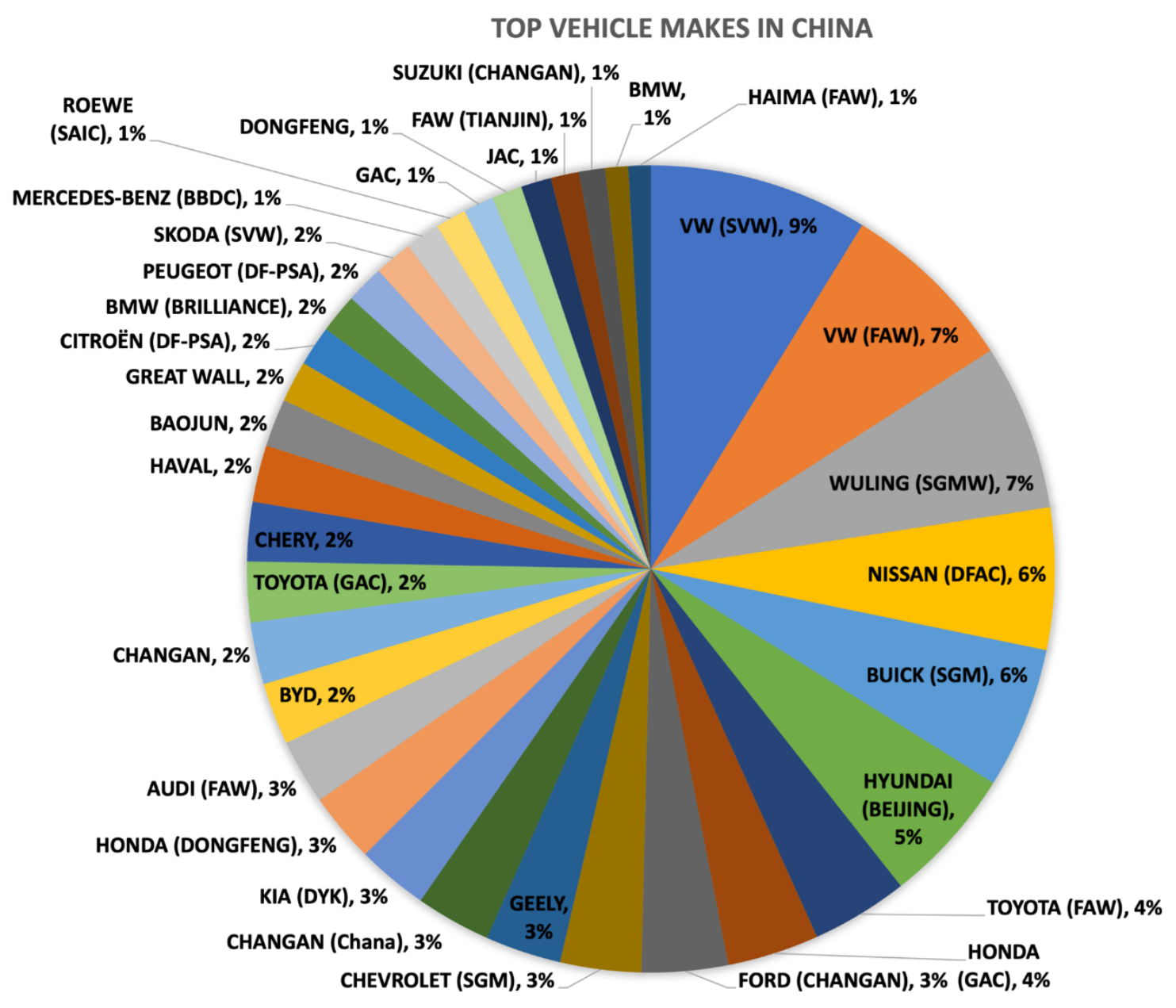

Figure C-2. Vehicle makers for China 


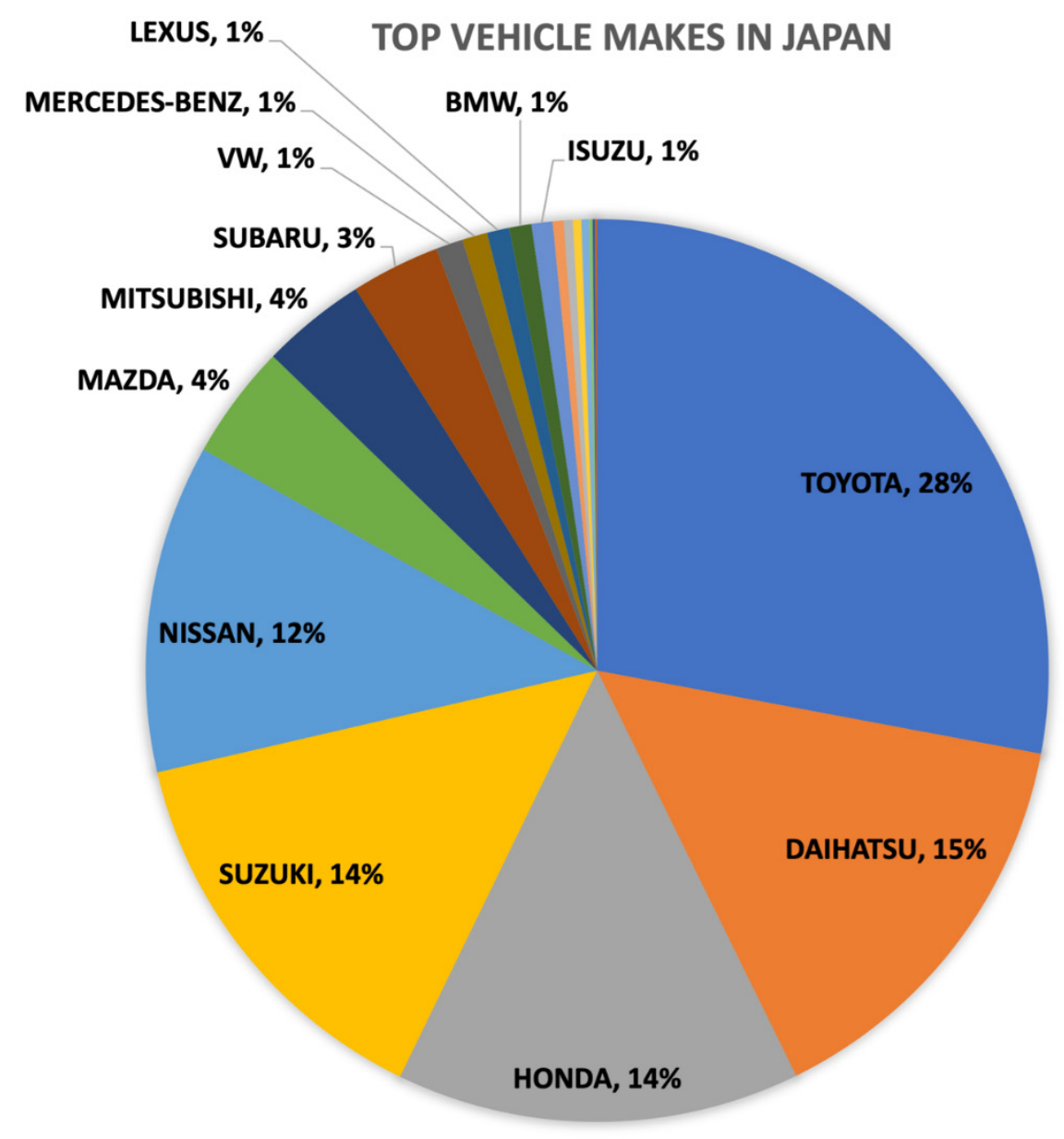

Figure C-3. Vehicles makers for Japan 


\section{TOP VEHICLE MAKES IN INDIA}

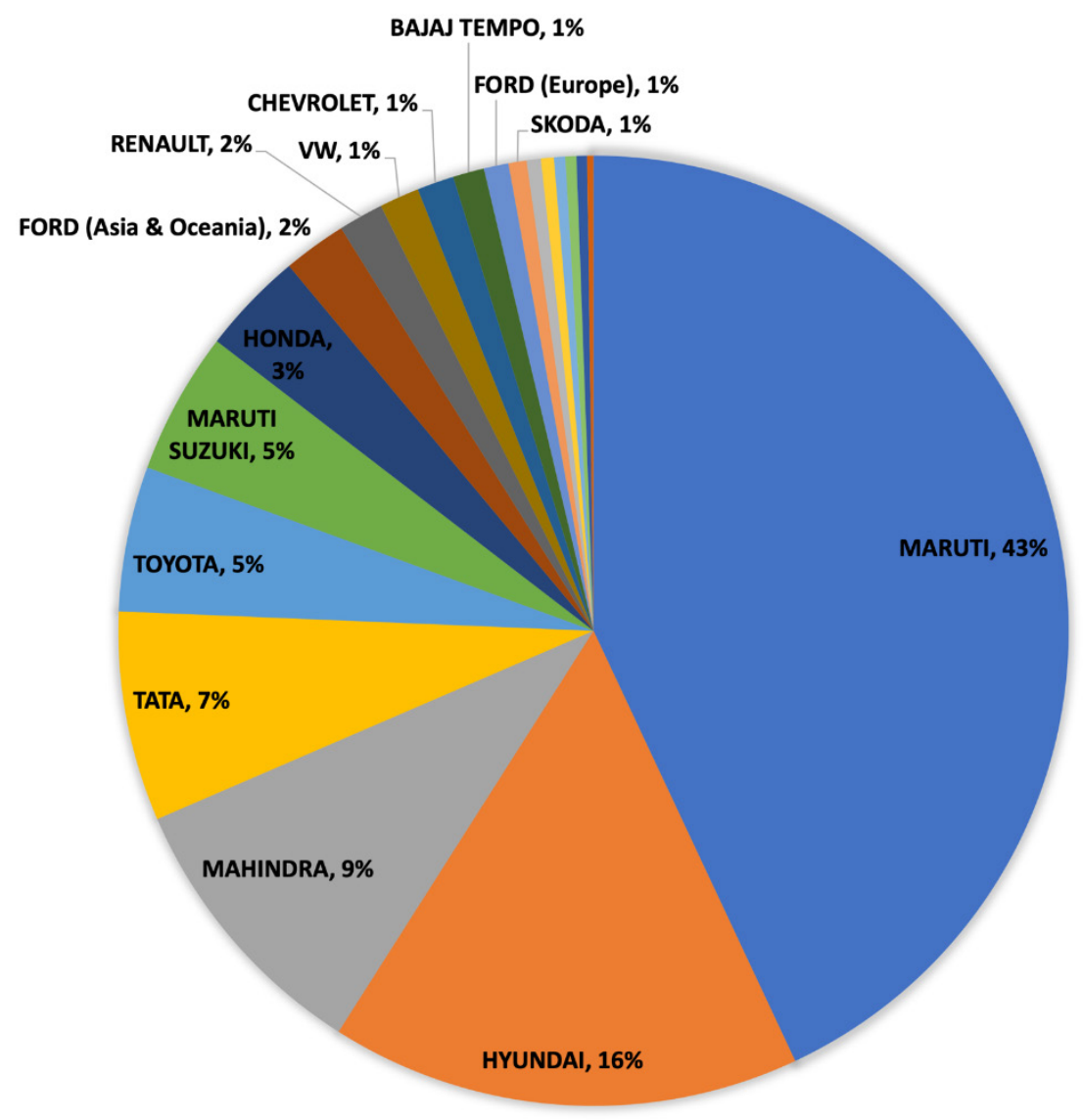

Figure C-4. Vehicle makers for India 


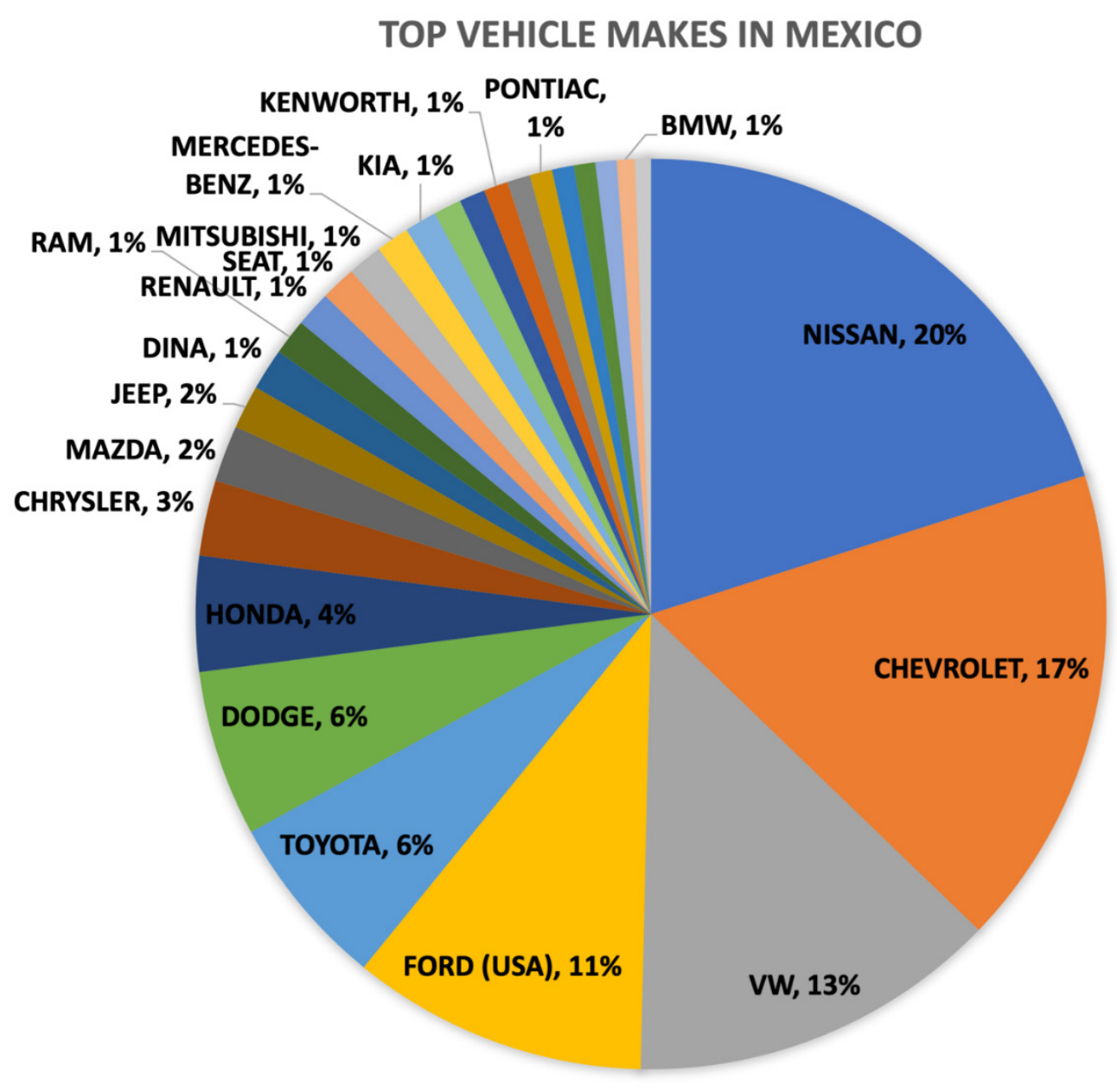

Figure C-5. Vehicle makers for Mexico 


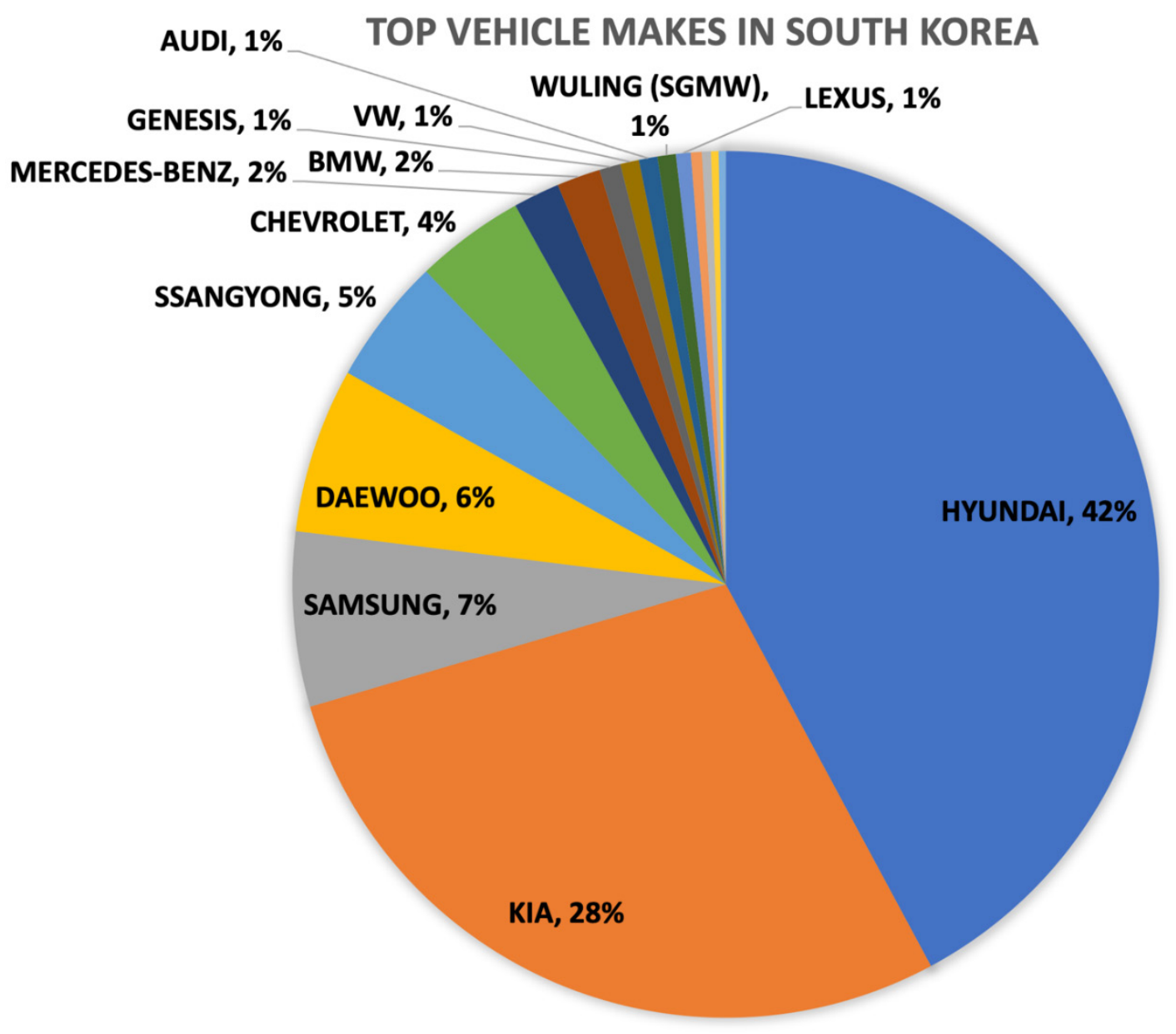

Figure C-6. Vehicle makers for South Korea 


\section{TOP VEHICLE MAKES IN CANADA}

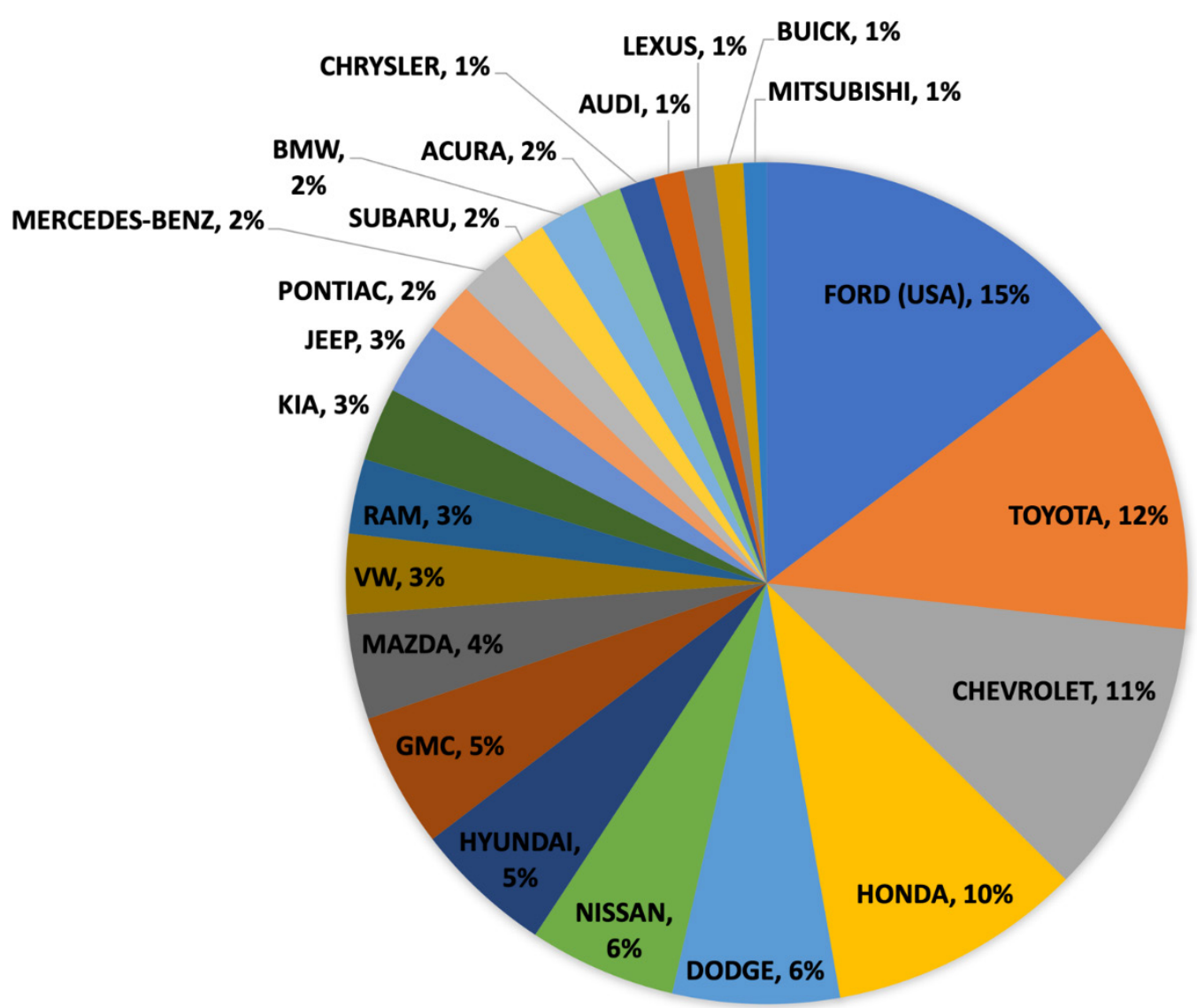

Figure C-7. Vehicles makers for Canada 


\section{TOP VEHICLE MAKES IN INDONESIA}

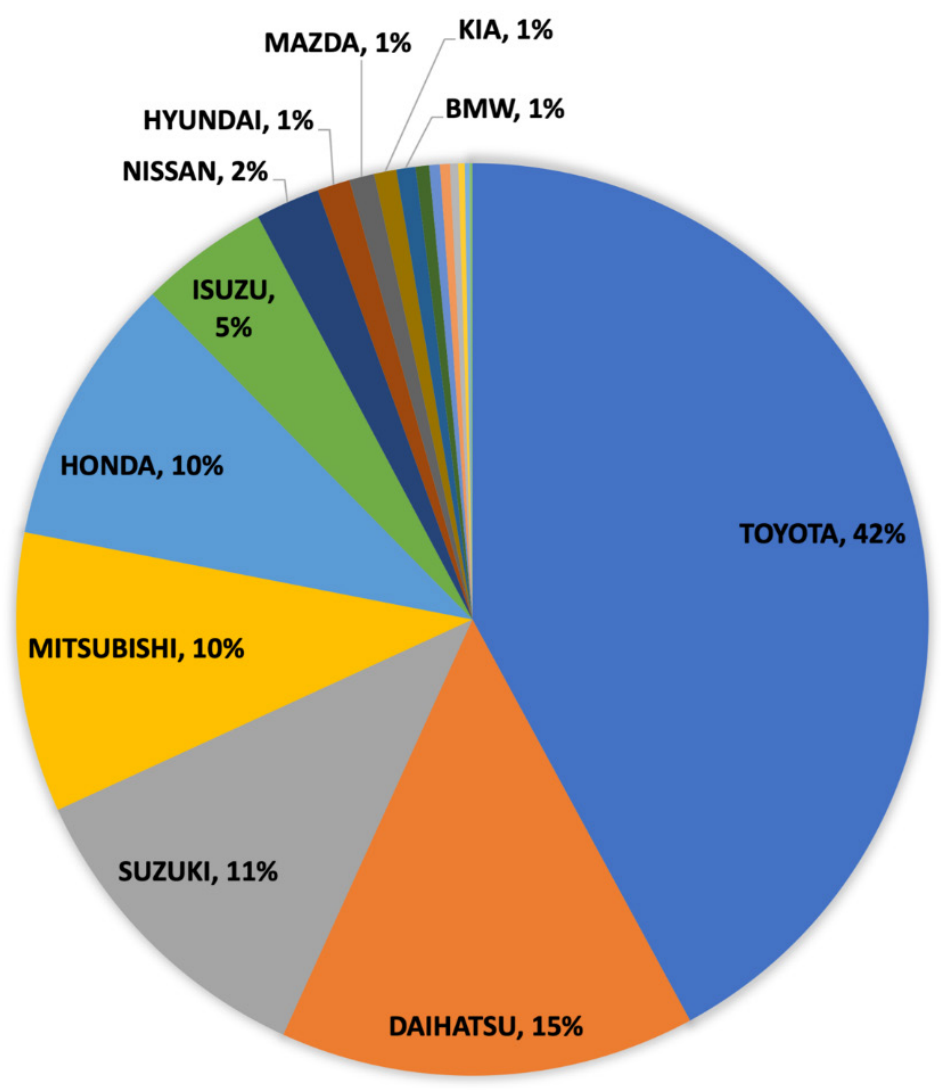

Figure C-8. Vehicle makers for Indonesia 


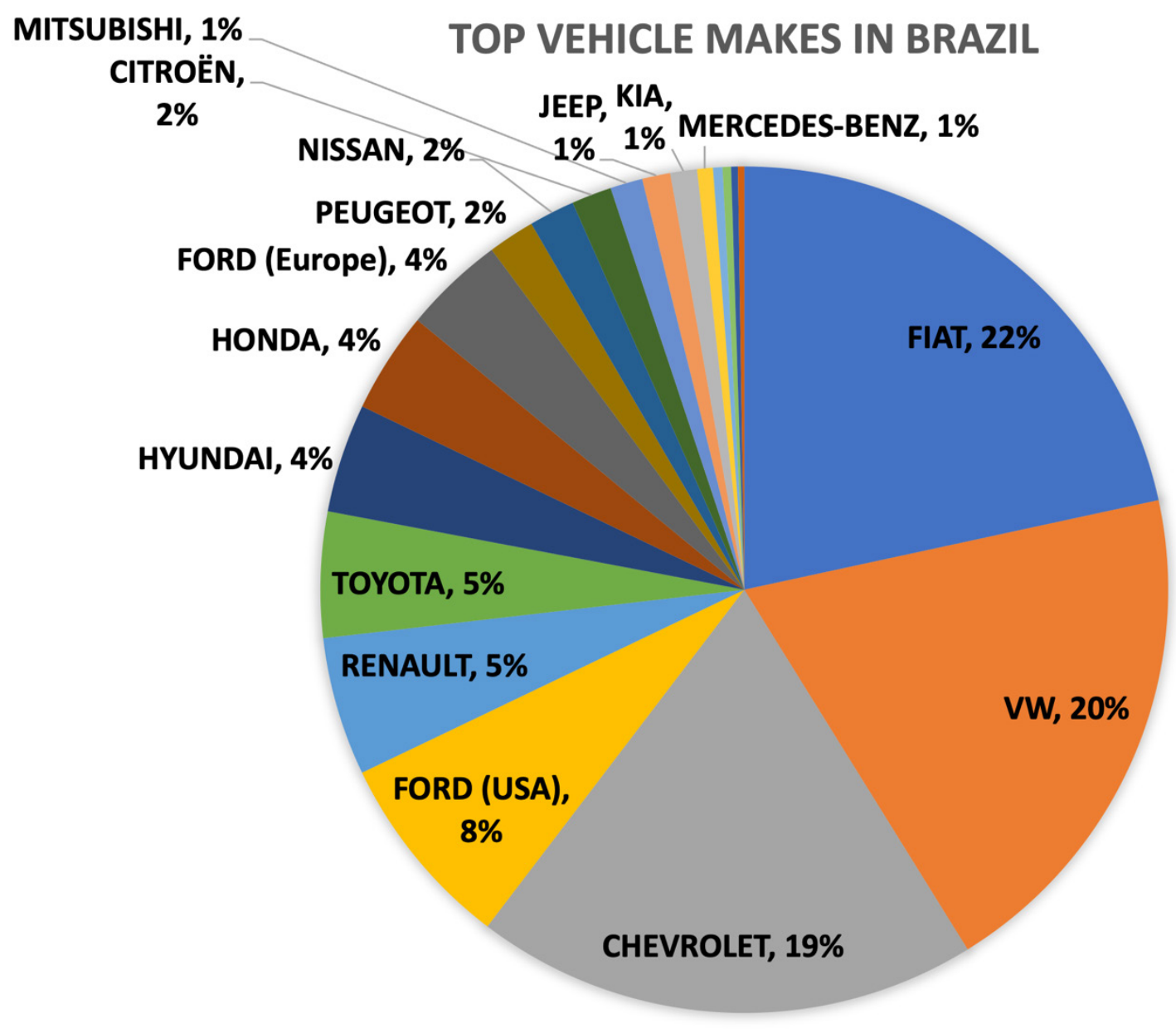

Figure C-9. Vehicle makers for Brazil

\section{Centralization of Country's Fleet Production}

If the fleet of LDVs in a country was manufactured by a few dominant companies rather than by an extremely decentralized, diverse set of companies, it could be more fertile ground for ethanol introduction. This is partially because each company that is producing ethanol-tolerant vehicles or could produce them in the future has much more sway over the market. Table $\mathrm{C}-1$ displays metrics of the relative centralization of the manufacturers in the studied countries.

Table C-1 shows that India has the most centralized vehicle market with only 49 manufacturers. Furthermore, only two manufacturers have more than 10\% market share and the largest (Maruti) makes $43 \%$ of all the vehicles in the country. Maruti's owners manuals for their top five models state that they are compatible with E10 (owners manual evaluations are discussed more below). Another manufacturer with particularly high market leverage is Toyota with $42 \%$ of the Indonesian market and $24 \%$ of the Japanese market. The limited owners manual search indicates that Toyota vehicles with a large foreign market share (such as the Corolla, Camry, Prius, and Vitz) are E10-compatible whereas models with a small foreign market share (such as the Pixis and Prius Alpha) are not approved to use ethanol. Unfortunately, we were unable to obtain an owner's manual for the Avanza, which is the most popular Toyota in Indonesia. The third manufacturer with high leverage is Hyundai with $41 \%$ of the South Korean market. Hyundai's 
most recent owner's manual publications (model years 2019-2020) indicate up to E10 compatibility.

Table C-1. Relative Centralization or Diversification of Vehicle Manufacturers, by Country

\begin{tabular}{|l|c|c|c|l|}
\hline Country & $\begin{array}{c}\text { Number of } \\
\text { Vehicle } \\
\text { Manufacturers }\end{array}$ & $\begin{array}{c}\text { \# Manufacturers } \\
\text { with } \mathbf{> 1 0 \%} \text { Market } \\
\text { Share }\end{array}$ & $\begin{array}{c}\text { \% Market Share of } \\
\text { Largest } \\
\text { Manufacturer }\end{array}$ & $\begin{array}{c}\text { Largest } \\
\text { Manufacturer }\end{array}$ \\
\hline India & 49 & 2 & 43 & Maruti \\
\hline Indonesia & 55 & 3 & 42 & Toyota \\
\hline USA & 85 & 3 & 15 & Ford \\
\hline Canada & 68 & 3 & 14 & Ford \\
\hline Brazil & 71 & 3 & 21 & Fiat \\
\hline Mexico & 72 & 4 & 19 & Nissan \\
\hline $\begin{array}{l}\text { South } \\
\text { Korea }\end{array}$ & 78 & 2 & 41 & Hyundai \\
\hline Japan & 96 & 5 & 28 & Toyota \\
\hline China & 260 & 0 & 7 & VW/Shanghai \\
\hline
\end{tabular}

Note: Manufacturers count separately if they have partnered with different Chinese manufacturers. Data Source: Experian VIO database, Q4 2019

Canada's vehicle market looks remarkably like the U.S. market in terms of diversification, centralization, and vehicle manufacturers. Mexico is similar to Brazil with the exception of Fiat's heavy presence in Brazil. In contrast to India, China has by far the most diverse vehicle market with 260 manufacturers and none of them manufacturing more than $10 \%$ of total vehicles.

\section{Manufacturer Crossover between Study Country and Ethanol- Compatible Markets}

A study country could have more ethanol-compatible vehicles if their fleet was manufactured largely by companies that sell into ethanol-using markets. For example, companies that produce vehicles compatible to Brazil's E27 market might be more capable of producing vehicles tolerant of ethanol in other markets. Table C-2 shows the top eight manufacturers in Brazil (responsible for $88 \%$ of their market) and the percent of vehicles they produced for the seven study countries. 
Table C-2. Top Manufacturers in Brazil and Their Share of the Markets in Study Countries (\%)

\begin{tabular}{|l|c|c|c|c|c|c|c|c|}
\hline \multicolumn{1}{|c|}{ Make } & Brazil & China & Japan & India & Mexico & $\begin{array}{c}\text { South } \\
\text { Korea }\end{array}$ & Canada & Indonesia \\
\hline FIAT & 21 & 0 & 0 & 0 & 0 & 0 & 0 & 0 \\
\hline VW & 19 & 13 & 1 & 1 & 13 & 1 & 3 & 0 \\
\hline CHEVROLET & 19 & 3 & 0 & 1 & 16 & 4 & 10 & 0 \\
\hline FORD & 11 & 3 & 0 & 3 & 12 & 0 & 14 & 1 \\
\hline RENAULT & 5 & 0 & 0 & 2 & 1 & 0 & 0 & 0 \\
\hline TOYOTA & 5 & 5 & 28 & 5 & 6 & 0 & 11 & 42 \\
\hline HYUNDAI & 4 & 4 & 0 & 16 & 1 & 41 & 5 & 1 \\
\hline HONDA & 4 & 5 & 14 & 3 & 4 & 0 & 9 & 10 \\
\hline
\end{tabular}

Note: Vehicles from the same manufacturer were aggregated without regard to production facility, location, or partners (in China). Data Source: Experian VIO databas,e Q4 2019

Volkswagen is responsible for $19 \%$ of the Brazilian market as well as $13 \%$ of the Chinese and Mexican markets. It is more likely that Mexico shares similar VW vehicles with Brazil than China due to its geographical proximity and because VWs manufactured in China are joint ventures with other Chinese manufacturers. Chevrolet and Ford both supply a large portion of the vehicles to Brazil, Mexico, and Canada, raising the possibility that these vehicles might be able to use E27 in all three countries, pending further investigation. VW and Chevrolet have manufacturing facilities in Mexico, Brazil, and the United States. However, these facilities only produce certain models, making it likely that they would need to send vehicles across these borders to fulfill market demand in multiple countries. Ford's vehicles are broken down by manufacturing location, with Ford USA responsible for 7\% of Brazil's vehicles and 10\% of Mexico's, while Ford Europe is responsible for 4\% of Brazil's vehicles and 1\% of Mexico's, and Ford Asia is responsible for 1\% of Mexico's vehicles. Toyota and Hyundai both sell many vehicles into the Brazilian market and a large portion of the Japanese and South Korean markets, respectively. However, these are domestic manufacturers in Japan and South Korea; therefore, they are much less likely to be producing E27 vehicles for their home markets.

Another ethanol-compatible market with which to compare vehicle manufacturers is the United States. Most of the gasoline in the United States has been E10 almost exclusively since 2011 (EIA 2011), so it is assumed that any vehicle in operation in the United States is compatible with at least E10. Table C-3 shows the most popular manufacturers in the United States (11 manufacturers accounting for $77 \%$ of the market) and their relative fleet composition in the study countries. 
Table C-3: Top Manufacturers in the United States and Their Share of the Markets in Study Countries

\begin{tabular}{|l|l|l|l|l|l|l|l|l|}
\hline \multicolumn{1}{|c|}{ Make } & USA & China & Japan & India & Mexico & $\begin{array}{l}\text { South } \\
\text { Korea }\end{array}$ & Canada & Indonesia \\
\hline FORD & $15 \%$ & $3 \%$ & $0 \%$ & $3 \%$ & $12 \%$ & $0 \%$ & $14 \%$ & $1 \%$ \\
\hline CHEVROLET & $14 \%$ & $3 \%$ & $0 \%$ & $1 \%$ & $16 \%$ & $4 \%$ & $10 \%$ & $0 \%$ \\
\hline TOYOTA & $12 \%$ & $0 \%$ & $28 \%$ & $5 \%$ & $6 \%$ & $0 \%$ & $11 \%$ & $42 \%$ \\
\hline HONDA & $8 \%$ & $0 \%$ & $14 \%$ & $3 \%$ & $4 \%$ & $0 \%$ & $9 \%$ & $10 \%$ \\
\hline NISSAN & $6 \%$ & $0 \%$ & $12 \%$ & $0 \%$ & $19 \%$ & $0 \%$ & $5 \%$ & $2 \%$ \\
\hline DODGE & $5 \%$ & $0 \%$ & $0 \%$ & $0 \%$ & $6 \%$ & $0 \%$ & $6 \%$ & $0 \%$ \\
\hline JEEP & $4 \%$ & $0 \%$ & $0 \%$ & $0 \%$ & $1 \%$ & $0 \%$ & $3 \%$ & $0 \%$ \\
\hline GMC & $4 \%$ & $0 \%$ & $0 \%$ & $0 \%$ & $0 \%$ & $0 \%$ & $5 \%$ & $0 \%$ \\
\hline HYUNDAI & $3 \%$ & $0 \%$ & $0 \%$ & $16 \%$ & $1 \%$ & $41 \%$ & $5 \%$ & $1 \%$ \\
\hline SUBARU & $2 \%$ & $0 \%$ & $3 \%$ & $0 \%$ & $0 \%$ & $0 \%$ & $2 \%$ & $0 \%$ \\
\hline KIA & $2 \%$ & $0 \%$ & $0 \%$ & $0 \%$ & $1 \%$ & $28 \%$ & $3 \%$ & $1 \%$ \\
\hline
\end{tabular}

Data Source: Experian VIO database, Q4 2019

Mexico and Canada have a heavy overlap with the United States when it comes to manufacturers. The 11 manufacturers in Table C-3 produced $76 \%$ of the vehicles in the United States, $67 \%$ in Mexico, and 74\% in Canada. Much like Brazil, the United States also has heavy overlap with Japan through its heavy usage of Toyota, Honda, Nissan, and Subaru. However, unlike Brazil, the U.S. market is much larger than Japan's. These four companies have produced 82 million vehicles for the U.S. market while only producing 47 million for the Japanese market. Despite these vehicles having different manufacturing facilities for the United States and Japanese markets, it is possible that their supply chain and components are E10-compatible since most of their vehicles are built for the E10 market of the US. If this is the case, the $52 \%$ of vehicles in Indonesia that are built by Toyota and Honda should also be E10 compatible. The large U.S. market could also be influential to the South Korean manufacturers for the same reason. Hyundai and Kia have nearly as many vehicles in the United States (15.4 million) as they do in South Korea (17 million).

\section{Vehicle Models}

Profiling the vehicle models of the study countries is useful for two reasons. First, the models have more consistency of all components (including nonengine components) than the vehicles grouped by manufacturer or a common engine code. Secondly, models can be tied to owners manuals that usually state ethanol limitations. Therefore, it is worth investigating trends in vehicle model stock across the seven study countries. This investigation was performed by cutting Experian's model data numerous ways, as shown in Table C-4.

The first line of Table C-4 shows that vehicle models are very decentralized with between 450 and 2,227 individual models in a given country. No single model surpasses $1.2 \%$ of the cumulative vehicles in the seven study countries. This diversity, which is by far the greatest in 
China, makes it more difficult to determine the portion of vehicles that can use ethanol. By contrast, India has the least diverse set of vehicle models with only 450.

Table C-4. Vehicle Model Statistics in Studied and Comparison Countries (\%)

\begin{tabular}{|l|c|c|c|c|c|c|c|c|c|}
\hline & China & Japan & India & Mexico & $\begin{array}{c}\text { South } \\
\text { Korea }\end{array}$ & Canada & $\begin{array}{c}\text { Indo- } \\
\text { nesia }\end{array}$ & Brazil & USA \\
\hline $\begin{array}{l}\text { Distinct Vehicle } \\
\text { Models }\end{array}$ & 2,227 & 1,961 & 450 & 1,261 & 1,143 & 1,568 & 779 & 958 & 1,749 \\
\hline $\begin{array}{l}\text { Name of top } \\
\text { model }\end{array}$ & $\begin{array}{c}\text { Wuling } \\
\text { Sun- } \\
\text { shine }\end{array}$ & $\begin{array}{c}\text { Suzuk } \\
\text { i Carry }\end{array}$ & $\begin{array}{c}\text { Murati } \\
\text { Alto }\end{array}$ & $\begin{array}{c}\text { Nissan } \\
\text { Tsuro }\end{array}$ & $\begin{array}{c}\text { Hyundai } \\
\text { Avante }\end{array}$ & $\begin{array}{c}\text { Ford } \\
\text { F150 }\end{array}$ & $\begin{array}{c}\text { Toyota } \\
\text { Avanza }\end{array}$ & VW Gol & F150 \\
\hline $\begin{array}{l}\text { Market share } \\
\text { of top model }\end{array}$ & 1.8 & 3.4 & 8.4 & 4.9 & 5.9 & 3.7 & 12.7 & 7.3 & 5.0 \\
\hline $\begin{array}{l}\text { Market share } \\
\text { of top 10 } \\
\text { models }\end{array}$ & 13.4 & 25.0 & 41.3 & 22.6 & 40.9 & 23.5 & 49.7 & 35.7 & 20.7 \\
\hline $\begin{array}{l}\text { Country with } \\
\text { highest overlap } \\
\text { of top 10 } \\
\text { models }\end{array}$ & Canada & India & Japan & US & Canada & US & Japan & Canada & Canada \\
\hline $\begin{array}{l}\text { Overlap with } \\
\text { most- } \\
\text { overlapping } \\
\text { country }\end{array}$ & 4.0 & 13.0 & 4.7 & 2.6 & 2.0 & 17.0 & 3.4 & 3.2 & 20.7 \\
\hline $\begin{array}{l}\text { Market share } \\
\text { of top 10 } \\
\text { models in } \\
\text { Brazil }\end{array}$ & 1.5 & 1.0 & 0.2 & 2.8 & 0.0 & 3.2 & 0.2 & 35.7 & 2.0 \\
\hline $\begin{array}{l}\text { Market share } \\
\text { of top 10 } \\
\text { models in US }\end{array}$ & 5.1 & 2.2 & 0.1 & 6.6 & 0.6 & 20.7 & 2.1 & 3.7 & 20.7 \\
\hline
\end{tabular}

Data Source: Experian VIO database, Q4 2019

The top models across the seven countries are shown in the second line of Table C-4. Three countries - Japan, Mexico, and Indonesia-have Japanese vehicles as their most popular models. Only the F150 is the most popular in more than one country - the United States and Canada.

Despite the diversity of vehicle models, there is great intercountry variation in the market share of the most popular models. Indonesia is the most centralized, with its most popular model claiming nearly $13 \%$ of the vehicle stock and its most popular 10 models achieving nearly $50 \%$. India is also quite centralized, with its most popular model claiming $8.4 \%$ and top 10 models claiming $41.3 \%$. China is the least centralized, with its top model accounting for less than $2 \%$ of the vehicles and the top 10 models accounting for only $13.4 \%$.

Overlap between top models could indicate similarities in ethanol compatibility. Table 10 displays overlap as the percent of market share in the study country that has been achieved by vehicle models that are on both countries' lists of top 10 most popular models. Four countries 
overlap the most with Canada, which has regional requirements of up to $10 \%$. Canada overlaps more than any other country with the United States (21\% overlap), China (4\%), Brazil (3.2\%), and South Korea (2\%). Japan is the country with the most overlap for two countries-India (13\% overlap) and Indonesia (3.4\%).

Of the seven study countries, Mexico has the most overlap with Brazil. The VW Gol, Fiesta, Corolla, Helix, Civic, and Corsa aggregate to $16.5 \%$ of the Brazilian vehicle stock and $4.9 \%$ of the Mexican vehicle stock. No other country comes close. Of the seven study countries, Canada has the most overlap with the United States. The top 10 models in the United States comprise $21 \%$ of the vehicle stock in both the United States and Canada. The same 10 models comprise $7 \%$ of the vehicle stock in Mexico, 5\% in China, 4\% in Brazil, 2\% in Japan and Indonesia, and $0 \%$ in India. 